\title{
Toekomstverkenning leerlingwezen
}

Citation for published version (APA):

de Grip, A., Berendsen, H., Borghans, L., \& Dekker, R. (1993). Toekomstverkenning leerlingwezen.

Researchcentrum voor Onderwijs en Arbeidsmarkt, Faculteit der Economische Wetenschappen. ROA Reports No. 4 https://doi.org/10.26481/umarep.1993004

Document status and date:

Published: 01/01/1993

DOI:

10.26481/umarep.1993004

Document Version:

Publisher's PDF, also known as Version of record

\section{Please check the document version of this publication:}

- A submitted manuscript is the version of the article upon submission and before peer-review. There can be important differences between the submitted version and the official published version of record.

People interested in the research are advised to contact the author for the final version of the publication, or visit the DOI to the publisher's website.

- The final author version and the galley proof are versions of the publication after peer review.

- The final published version features the final layout of the paper including the volume, issue and page numbers.

Link to publication

\footnotetext{
General rights rights.

- You may freely distribute the URL identifying the publication in the public portal. please follow below link for the End User Agreement:

www.umlib.nl/taverne-license

Take down policy

If you believe that this document breaches copyright please contact us at:

repository@maastrichtuniversity.nl

providing details and we will investigate your claim.
}

Copyright and moral rights for the publications made accessible in the public portal are retained by the authors and/or other copyright owners and it is a condition of accessing publications that users recognise and abide by the legal requirements associated with these

- Users may download and print one copy of any publication from the public portal for the purpose of private study or research.

- You may not further distribute the material or use it for any profit-making activity or commercial gain

If the publication is distributed under the terms of Article $25 \mathrm{fa}$ of the Dutch Copyright Act, indicated by the "Taverne" license above, 
TOEKOMSTVERKENNING LEERLINGWEZEN

ROA-R-1993/4
A. de Grip
$H$. Berendsen
L. Borghans
R.J.P. Dekker

RESEARCHCENTRUM VOOR ONDERWIJS EN ARBEIDSMARKT

Rijksuniversiteit Limburg

Faculteit der Economische Wetenschappen

Maastricht, september 1993 
CIP-GEGEVENS KONINKLIJKE BIBLIOTHEEK, DEN HAAG

\section{Toekomstverkenning}

Toekomstverkenning leerlingwezen / A. de Grip ... [et al.]. - Maastricht : Researchcentrum voor Onderwijs en Arbeidsmarkt, Rijksuniversiteit Limburg, Faculteit der Economische Wetenschappen. - ([Rapport] / Researchcentrum voor Onderwijs en Arbeidsmarkt, ISSN 09228098; ROA-R-1993/4)

Met lit. opg.

ISBN 90-5321-110-1 geb.

Trefw.: leerlingwezen ; toekomst. 


\section{INHOUDSOPGAVE}

Bladzijde

1. INLEIDING

1

1.1. Aanleiding tot het onderzoek 1

1.2. Probleemstelling 3

1.3. Onderzoeksopzet 4

1.4. Databronnen 5

1.5. Opzet van het rapport 7

2. DE INSTROOM IN DE PRIMAIRE OPLEIDINGEN 9

2.1. Inleiding 9

2.2. De ontwikkeling van de instroom in het verleden 9

2.3. Beleidsdoelstellingen 22

2.4. Het instroommodel voor de primaire opleidingen 27

2.5. Verwachte instroom primaire opleidingen 1993-2001 32

2.6. Verwachte aanbodoverschotten en -tekorten 1993-2001 38

3. DE UITSTROOM UIT DE PRIMAIRE OPLEIDINGEN 40

3.1. Inleiding 40

3.2. De ontwikkeling van de uitstroom in het verleden 40

3.3. Het uitstroommodel van de primaire opleidingen 42

3.4. Verwachte uitstroom gediplomeerden van de
primaire opleidingen 1993-2001

4. ENKELE ALTERNATIEVE SCENARIO'S 54

4.1. Inleiding 54

4.2. Instroom vrouwen 55

4.3. Instroom voortijdig schoolverlaters $\quad 57$

4.4. Dualisering KMBO 59

4.5. Verhoging interne rendement 61

5. BESLUIT

$\begin{array}{ll}\text { LITERATUUR } & 70\end{array}$

BIJLAGE A. LANDELIJKE ORGANEN VOOR HET LEERLINGWEZEN 73

BIJLAGE B. JAARCIJFERS SAMENSTELLING INSTROOM, 1978-1991 74

BIJLAGE C. VRAGENLIJST M.B.T. INFORMATIE OVER BELEIDSDOELSTELLINGEN LANDELIJKE ORGANEN

BIJLAGE D. JAARCIJFERS INSTROOMPROGNOSES, 1993-2001 79

BIJLAGE E. JAARCIJFERS PROGNOSES AANBODOVERSCHOTTEN EN -TEKORTEN, 1993-2001 80

BIJLAGE F. JAARCIJFERS PROGNOSES GEDIPLOMEERDE UITSTROOM, 1993-2001 81 



\section{INLEIDING}

\subsection{Aanleiding tot het onderzoek}

Binnen het Nederlandse onderwijsstelsel neemt het leerlingwezen een speciale positie in. Karakteristiek voor het leerlingwezen ten opzichte van de andere vormen van beroepsonderwijs is de duale opleidingsstructuur. De opleidingen bestaan uit een theoriegedeelte en een praktijkcomponent. Voor het theoretische deel van de opleiding - het algemene en het op het beroep gerichte onderwijs - bezoeken de leerlingen doorgaans één of twee dagen per week een school voor beroepsbegeleidend onderwijs. Gedurende de rest van de werkweek zijn zij werkzaam in de praktijk van het beroep. Op dit praktijkgedeelte van de opleiding ligt het accent. In het algemeen berust de verantwoordelijkheid voor de verzorging van de praktijkopleiding bij de werkgever waarmee de leerling een leerovereenkomst heeft afgesloten. Vaak wordt bij het afsluiten van een leerovereenkomst tevens een arbeidsovereenkomst aangegaan. Door deze koppeling, die meestal in een Collectieve Arbeidsovereenkomst is vastgelegd, wordt de leerling tegelijkertijd werknemer. In dit verband wordt de praktijkopleidingsplaats ook vaak aangeduid als leer-arbeidsplaats (vgl. Hövels, 1985; Van Imhoff, 1986; Diederen, 1987; Frietman, 1990; Ganga, 1992).

Het leerlingwezen verzorgt beroepsopleidingen op primair en voortgezet niveau. Het primaire leerlingwezen leidt op tot het niveau van beginnend beroepsbeoefenaar. De voortgezette opleidingen vergroten de vakbekwaamheid tot het niveau van zelfstandig beroepsbeoefenaar. De formele opleidingsduur van de primaire opleidingen bedraagt twee of drie jaar. De voortgezette opleidingen duren nominaal één of twee jaar.

Het leerlingwezen vormt een belangrijke schakel in de directe aansluiting tussen onderwijs en arbeidsmarkt. Enkele jaren geleden benadrukte de Commissie Rauwenhoff nog eens dat het duale leer-werktraject in een vloeiende overgang tussen beroepsopleiding en beroepsuitoefening voorziet. Op grond hiervan pleit de commissie voor de invoering van een duale opleidingsstructuur in alle vormen van beroepsonderwijs (zie Tijdelijke Adviescommissie Onderwijs en Arbeidsmarkt, 1990).

Cruciaal voor de positie van het leerlingwezen in de verzorging van de initiële opleiding van vaklieden zijn het aanbod van praktijkopleidingsplaatsen door arbeidsorganisaties en de vraag naar praktijkopleidingsplaatsen door leerlingen. Enige verwarring kan optreden doordat de termen vraag en aanbod in het leerlingwezen verschillend kunnen worden gebruikt. Het aanbod van leer-arbeidsplaatsen is tegelijkertijd op te vatten als vraag naar leerlingen, terwijl de vraag naar leer-arbeidsplaatsen tevens als aanbod van leerlingen kan worden geïnterpreteerd. De vraag naar leerlingen wordt in belangrijke mate beïnvloed door de conjuncturele ontwikkeling (zie Geurts, 1989; Frietman, 1990). Het aanbod van leerlingen is vooral afhankelijk van demografische factoren en van ontwikkelingen in het studie- en beroepskeuzegedrag van jongeren. 
In het leerlingwezen kunnen er in twee opzichten discrepanties tussen vraag en aanbod ontstaan. Enerzijds kan de vraag naar leerlingen achterblijven bij het aanbod. Anderzijds kan het aanbod van leerlingen tekortschieten ten opzichte van de vraag. Het eerste geval deed zich voor in het begin van de jaren tachtig. Het aanbodoverschot van leerlingen in combinatie met het dreigende toekomstige tekort aan geschoolde arbeidskrachten leidde er toe dat door de sociale partners, het onderwijsveld en de overheid als resultaat van het zogenaamde Open Overleg over de voorstellen van de Commissie Wagner gezamenlijke afspraken zijn gemaakt over de versterking van het leerlingwezen (zie Adviescommissie inzake de Voortgang van het Industriebeleid, 1983 en Ministerie van Onderwijs en Wetenschappen, 1984). Daarbij werd gestreefd naar een verdubbeling van het aantal afgesloten leerovereenkomsten ten opzichte van het ijkjaar 1982.

Doordat deze zogenaamde verdubbelingsoperatie in haar opzet is geslaagd, is het probleem van het tekort aan leer-arbeidsplaatsen verdwenen. Aan het einde van de jaren tachtig begint zich echter langzamerhand een omgekeerde situatie af te tekenen (zie Hövels en Verijdt, 1987; Ministerie van Sociale Zaken en Werkgelegenheid, 1988; Frietman, 1990; Frietman en Hövels, 1990). Het aanbod van leerlingen dreigt geringer te worden dan de vraag, een tendens die mede door de verwachte ontgroening van de beroepsbevolking in de nabije toekomst waarschijnlijk nog wordt versterkt.

De vrees voor een tekortschietend aanbod van leerlingen in het leerlingwezen wordt gevoed door de afnemende uitstroom van schoolverlaters uit het initiële dagonderwijs. Zorgwekkend is in dit verband met name de daling van de uitstroom uit het Lager Beroepsonderwijs (LBO) ${ }^{1}$ en het Middelbaar Algemeen Voortgezet Onderwijs (MAVO). Als oorzaken van de geringere uitstroom uit deze traditionele vooropleidingen van het leerlingwezen kunnen worden genoemd:

- de afnemende instroom in het LBO en het MAVO als gevolg van demografische ontwikkelingen;

- de grotere doorstroom naar vervolgopleidingen binnen het dagonderwijs;

- de negatieve beeldvorming met betrekking tot het LBO, waardoor dit onderwijs steeds meer het karakter is gaan krijgen van 'restonderwijs'.

Lang niet alle leerlingen ronden een opleiding in het leerlingwezen met succes af. Gezien de verwachte toekomstige behoefte aan geschoolde arbeidskrachten is derhalve niet alleen de ontwikkeling van de instroom van belang, maar ook het longitudinale interne rendement van de opleidingen in het leerlingwezen. Wat dit laatste betreft, geven indicatieve berekeningen van het Ministerie van Onderwijs en Wetenschappen aanleiding tot ongerustheid. Deze ongerustheid wordt ingegeven door de constatering dat het rendement in het leerlingwezen zeer laag ligt in

1. Per 1 augustus 1992 is het Lager Beroepsonderwijs geherstructureerd. Sindsdien wordt gesproken van Voorbereidend Beroepsonderwijs (VBO). De schoolsoorten Lager Technisch Onderwijs (LTO), Lager Huishoud- en Nijverheidsonderwijs (LHNO), Lager Middenstandsonderwijs (LMO), Lager Economisch en Administratief Onderwijs (LEAO), en Lager Agrarisch Onderwijs (LAO) zijn verdwenen en vervangen door afdelingen. In deze studie zullen echter nog de oude benamingen worden gehanteerd, omdat het beschikbare datamateriaal hierop is gebaseerd. 
vergelijking tot het dagonderwijs (zie Ganga, 1992). Ook uit andere studies blijkt dat er in het leerlingwezen sprake is van een hoog percentage (voortijdige) uitvallers (zie De Bont-Hoek, De Haas en Kraft, 1989; De Kleine en Stevens, 1989; Merkus, 1990; Beereboom, 1991; Gelderblom en Hammink, 1991; Neve, 1991).

Over de toekomstige ontwikkeling van het leerlingwezen is slechts in zeer beperkte mate informatie beschikbaar. Sinds 1992 is het leerlingwezen opgenomen in het hoofdmodel van de zogenaamde Referentieraming van het Ministerie van Onderwijs en Wetenschappen (1992). Daarmee is het mogelijk geworden om binnen deze Referentieraming prognoses op te stellen van de toekomstige deelname aan het leerlingwezen. Het aggregatieniveau van deze prognoses is echter te hoog om aan te kunnen geven welke bedrijfssectoren in de toekomst problemen bij de werving van leerlingen zouden kunnen ondervinden. Derhalve is het wenselijk prognoses op te stellen op een lager aggregatieniveau. In deze studie is het mogelijk de schatting van de coëfficiënten van de prognosemodellen te baseren op gegevens over een langere historische waarnemingsperiode, hetgeen de betrouwbaarheid van de schattingen ten goede komt. Bovendien bieden de geschatte modellen meer mogelijkheden voor scenariovorming.

\subsection{Probleemstelling}

Vanwege de belangrijke positie van het leerlingwezen als schakel in de directe aansluiting tussen onderwijs en arbeidsmarkt is het van groot belang de mogelijke toekomstige knelpunten voor de handhaving en de verdere uitbouw van deze positie in kaart te brengen. In het licht van de in de vorige paragraaf geschetste ontwikkelingen gaat het daarbij met name om de vraag in hoeverre het aanbod van leerlingen voor de primaire opleidingen van het leerlingwezen in de (nabije) toekomst tekort zou kunnen schieten ten opzichte van de vraag naar leerlingen door arbeidsorganisaties in de verschillende bedrijfssectoren. Daarnaast is het van belang een antwoord te geven op de vraag hoe de toekomstige uitstroom uit de primaire opleidingen van het leerlingwezen zich zal ontwikkelen. Hiertoe dient de ontwikkeling van het longitudinale interne rendement van de opleidingen in beeld te worden gebracht. Het rendement van de diverse opleidingen in het leerlingwezen is immers medebepalend voor de toekomstige gediplomeerde uitstroom, welke op zijn beurt weer van groot belang is voor het toekomstige aanbod van geschoolde arbeidskrachten.

De toekomstverkenning heeft betrekking op de te verwachten in- en uitstroom van leerlingen in het primaire leerlingwezen in de periode 1993-2001. Daarbij gaat het om leerlingen die zowel de theorie- als de praktijkcomponent van een leerlingwezenopleiding volgen. Leerlingen zonder leerovereenkomst blijven derhalve buiten beschouwing. Alleen bij de beschrijving van de historische ontwikkeling van de instroom worden hierop enkele uitzonderingen gemaakt.

Het longitudinale interne rendement wordt gedefinieerd als het percentage leerlingen van een bepaald instroomjaar dat de primaire opleiding succesvol afsluit. Met succesvol afsluiten wordt bedoeld dat zowel het examen van het theoriegedeelte als het examen van het praktijkgedeelte met goed gevolg is afgelegd, i.c. het volledig diploma is behaald. Leerlingen die alleen voor het 
examen van de praktijkcomponent zijn geslaagd en op grond daarvan een praktijkgetuigschrift hebben ontvangen, worden derhalve niet tot de categorie 'succesvol' gerekend. Dit geldt eveneens voor leerlingen die niet alle certificaten van een gemoduleerde opleiding hebben behaald.

Het complement van het longitudinale interne rendement is het uitvalpercentage. Dit is dus het percentage leerlingen van een bepaald instroomjaar dat de primaire opleiding zonder volledig diploma verlaat. Zowel leerlingen die de opleiding reeds voor het examen vaarwel zeggen als leerlingen die uiteindelijk niet voor het examen weten te slagen, worden daarbij tot de uitval gerekend.

\subsection{Onderzoeksopzet}

In het leerlingwezen zijn er 31 landelijke opleidingsorganen die verantwoordelijk zijn voor de vakinhoudelijke kant van de opleidingen. Deze landelijke organen zijn min of meer bedrijfstaksgewijs georganiseerd. Zij zijn belast met het opstellen van de opleidingsprogramma's, de zogenaamde totaalprogramma's, en het afnemen van de examens. Daarnaast zijn zij betrokken bij het afsluiten van leerovereenkomsten en begeleiden zij de leerling bij het praktijkgedeelte van de opleiding. Tot voor kort waren er naast de landelijke organen 15 regionale organen. Deze regionale organen zijn per 1 januari 1993 opgegaan in de zogenaamde Regionale Dienstverlenende Centra (RDC's), inmiddels ook wel aangeduid als de Adviescentra voor Opleiding en Beroep (AOB's). Naast hun algemene taak op het gebied van studie- en beroepskeuzevoorlichting, dragen deze RDC's/AOB's zorg voor de sociaal-pedagogische begeleiding van de leerlingen in het leerlingwezen.

In dit onderzoek is gekozen voor een analyse op het niveau van de landelijke opleidingsorganen. Daarbij worden de drie organen die onder de verantwoordelijkheid van het Ministerie van Landbouw, Natuurbeheer en Visserij vallen, buiten beschouwing gelaten. Vanwege de geringe aantallen leerlingen en/of twijfels over de betrouwbaarheid van het datamateriaal zijn ook vier van de resterende 28 organen die onder het Ministerie van Onderwijs en Wetenschappen ressorteren, buiten het onderzoek gebleven.

Bij de schatting van het longitudinale interne rendement van de opleidingen in het leerlingwezen en het opstellen van prognoses van de toekomstige in- en uitstroom is voortgebouwd op een door Lodder, De Grip en Heijke (1992) ontwikkelde methodiek. In deze methodiek werd uitgegaan van een indeling in sectoren. Zoals gezegd, is hier echter gekozen voor een analyse op het niveau van de landelijke opleidingsorganen. Allereerst is op basis van historische data over de periode 1978-1991 een schatting gemaakt van de coëfficiënten van een model waarmee de jaarlijkse instroom in de primaire opleidingen kan worden verklaard. In dat model wordt de instroom afhankelijk gesteld van de uitstroom uit de relevante vooropleidingen in het initiële dagonderwijs. Door gebruik te maken van het geschatte instroommodel is met behulp van prognoses van de verwachte uitstroom uit de relevante vooropleidingen een berekening gemaakt van de op middellange en lange termijn te verwachten instroom in de primaire 
opleidingen. Vervolgens is becijferd hoe de te verwachten instroom zich zal verdelen over de landelijke opleidingsorganen.

Om na te gaan of het aanbod van leerlingen al dan niet toereikend zal zijn om gedurende de prognoseperiode aan de door arbeidsorganisaties uitgeoefende vraag te voldoen, wordt de instroomprognose geconfronteerd met de vraag zoals deze gekwantificeerd kan worden met behulp van de streefcijfers die de landelijke opleidingsorganen jaarlijks opstellen in het kader van de Bijdrageregeling Vakopleiding Leerlingwezen (BVL). Deze BVL is de voortzetting van de Bijdrageregeling Vakopleiding Jeugdigen (BVJ) die in een aantal sectoren een positieve bijdrage heeft geleverd aan de vergroting van de instroom in het leerlingwezen (zie De Grip, Heijke en Lodder, 1992).

Aansluitend op de analyse van de instroom in de primaire opleidingen is voor elk van de in het onderzoek betrokken landelijke opleidingsorganen een schatting gemaakt van de coëfficiënten van een 'rendements'model waarin de uitstroom uit de primaire opleidingen in een bepaald jaar wordt verklaard uit de instroom in eerdere jaren. Doordat de jaarlijkse uitstroom wordt gerelateerd aan de instroom in voorafgaande jaren, wordt op basis van dit model inzicht verkregen in het longitudinale interne rendement van de primaire opleidingen. Om na te gaan of er in de loop der tijd eventuele verschuivingen in het interne rendement zijn opgetreden, is het uitstroommodel ook voor twee deelperiodes (1980-1985 en 1986-1991) geschat. Vervolgens is met behulp van het geschatte uitstroommodel en de verwachtingen ten aanzien van de toekomstige instroom een prognose opgesteld van de toekomstige jaarlijkse uitstroom van de primaire opleidingen.

In aanvulling op het basisscenario van de te verwachten in- en uitstroom van leerlingen in de jaren 1993-2001, zijn enkele alternatieve scenario's opgesteld. Deze beleidsscenario's geven een beeld van de beleidsdoelen die gesteld moeten worden, wanneer langs een bepaald traject getracht wordt om de verwachte tekorten aan leerlingen te voorkomen. Daarbij wordt achtereenvolgens ingegaan op de vereiste beleidsdoelstellingen op een viertal terreinen:

- het verhogen van de instroom van vrouwen;

- het verhogen van de instroom van voortijdig schoolverlaters;

- het verhogen van de instroom door dualisering van het Kort Midddelbaar Beroepsonderwijs (KMBO);

- het verhogen van het (interne) rendement van de primaire opleidingen.

Bij de bespreking van deze scenario's zal telkens worden aangegeven in hoeverre het in principe mogelijk is om langs de desbetreffende weg de verwachte tekorten aan leerlingen te voorkomen.

\subsection{Databronnen}

Voor het schatten van de coëfficiënten van de modellen zijn historische in- en uitstroomcijfers per landelijk orgaan vereist. Daarbij gaat het met name om het jaarlijkse aantal nieuwe leerlingen naar vooropleiding, het jaarlijkse aantal geslaagden en het jaarlijkse aantal uitvallers. De 
belangrijkste databronnen waaraan deze gegevens zijn ontleend, zijn de Statistiek van het beroepsonderwijs en de Statistiek volwasseneneducatie: beroepsbegeleidend onderwijs en vormingswerk, cursorisch ondernemersonderwijs van het Centraal Bureau voor de Statistiek (CBS), de Leerovereenkomst (LOK)-tellingen van het Ministerie van Onderwijs en Wetenschappen (O\&W) en de Statistische jaargegevens van de regionale organen voor het leerlingwezen van de Stichting Centraal Orgaan Regionale Organen leerlingwezen (CORO).

Enerzijds vullen de drie genoemde databronnen elkaar aan, anderzijds is er sprake van overlappingen, waarbij er overigens wel verschillen optreden in de gehanteerde indelingen en de lengte van de beschikbare tijdreeksen. Zo hebben de data van het CBS betrekking op het totale aantal leerlingen en het jaarlijkse aantal geslaagden. Tot 1983 zijn deze cijfers uitgesplitst naar niveau (primair, voortgezet) en cursussoort. Vanaf 1983 vindt een uitsplitsing naar niveau en vakrichting plaats. Door koppeling van de LOK-tellingen aan het Cursusaanvraagregistratiesysteem (CARS) en de Basisregistratie Instellingen (BRIN) zijn voor de jaren 19881991 gegevens gegenereerd over het jaarlijkse aantal nieuwe leerlingen, het jaarlijkse aantal geslaagden en het jaarlijkse aantal uitvallers per landelijk orgaan bij zowel de primaire als de voortgezette opleidingen. Aan de CORO-statistieken zijn voor de jaren 1978-1991 cijfers ontleend over het totale aantal primaire leerovereenkomsten naar vooropleiding per landelijk orgaan $^{2}$. Naast de traditionele instroom uit het LBO en het MAVO kan voor de jaren 1989-1991 ook de instroom uit het Hoger Algemeen Voortgezet Onderwijs (HAVO) en het Middelbaar Beroepsonderwijs (MBO) worden getraceerd ${ }^{3}$. Verder geven de gegevens van het CORO inzicht in het jaarlijkse aantal geslaagden en het jaarlijkse aantal uitvallers per landelijk orgaan, waarbij de primaire en de voortgezette opleidingen afzonderlijk worden beschouwd.

Bij het samenstellen van de dataset voor de schattingen zijn de CBS-gegevens als uitgangspunt genomen. Deze gegevens vormen vanaf 1976 een aaneengesloten reeks. Derhalve is er voor gekozen om de datareeksen die voor de schattingen zijn gebruikt in dit jaar te laten beginnen ${ }^{4}$. Om de data van het CBS te transformeren naar cijfers per landelijk orgaan is gebruik gemaakt van de reeds genoemde CARS- en BRIN-bestanden. Met behulp van deze bestanden kan elke afzonderlijke cursus zowel onder een vakrichting als onder een landelijk orgaan worden gerangschikt.

De verdere opbouw van de datareeksen heeft plaatsgevonden op een wijze die in belangrijke mate overeenkomt met de door Lodder, De Grip en Heijke (1992) ontwikkelde aanpak. De CORO-statistieken zijn gebruikt om voor de jaren 1976-1987 uitval- en slagingspercentages te berekenen. Deze percentages zijn vervolgens op de CBS-gegevens geprojecteerd. Hierdoor

2. Over de vooropleiding van de leerlingen in de voortgezette opleidingen bevatten de COROstatistieken slechts gegevens voor de jaren 1989-1991.

3. Voor het HAVO was dit overigens ook al mogelijk voor de jaren 1978-1980.

4. De reeks voor de schatting van het instroommodel voor de primaire opleidingen begint in 1978, omdat de CORO-gegevens over de vooropleiding van de leerlingen per landelijk orgaan pas vanaf dat jaar beschikbaar waren. 
wordt een schatting verkregen van het jaarlijkse aantal nieuwe leerlingen en het jaarlijkse aantal uitvallers per landelijk orgaan. Deze geschatte gegevens voor de jaren 1976-1987 zijn aangevuld met de feitelijke gegevens voor de jaren 1988-1991, zodat een reeks voor de hele periode 1976-1991 resulteert.

Om voor elk van de landelijke organen een reeks te verkrijgen van het jaarlijkse aantal nieuw afgesloten primaire leerovereenkomsten naar vooropleiding, is gebruik gemaakt van de verdeling van het totale aantal primaire leerovereenkomsten naar vooropleiding die uit de COROstatistieken kan worden berekend. Naast deze historische instroomcijfers zijn voor het schatten van de parameterwaarden van het instroommodel voor de primaire opleidingen gegevens noodzakelijk over de uitstroom uit de relevante vooropleidingen in het initiële dagonderwijs. Deze zijn onttrokken aan de onderwijsmatrices van het CBS.

Voor het opstellen van de instroomprognoses voor de primaire opleidingen in de jaren 19932001 zijn prognoses vereist van de toekomstige uitstroom uit het initiële dagonderwijs. Hiervoor is gebruik gemaakt van de Referentieraming van het Ministerie van Onderwijs en Wetenschappen (1992). Daarin zijn prognoses opgenomen van de toekomstige uitstroom uit de diverse schoolsoorten. De prognoseperiode loopt van 1991/'92 tot en met 2009/'10.

Ten behoeve van de kwantificering van de toekomstige vraag naar leerlingen zijn door de sector Scholing en Intermediaire Voorzieningen van het Centraal Bureau voor de Arbeidsvoorziening gegevens verstrekt over de instroomdoelstellingen die de landelijke opleidingsorganen in de jaren 1990-1992 hebben ingediend voor het verkrijgen van een tegemoetkoming in het kader van de BVL. Daarnaast is van een aantal landelijke opleidingsorganen aanvullende informatie verkregen over de doelstellingen ten aanzien van de toekomstige instroom.

Voor de berekening van de indicatoren met betrekking tot de ontwikkeling van de instroom naar geslacht en naar leeftijd is gebruik gemaakt van de Opgave Van Leerlingwezen (OVL)-bestanden van het Ministerie van Onderwijs en Wetenschappen. Weliswaar hebben deze bestanden betrekking op de theoriecomponent van het leerlingwezen en kan niet worden vastgesteld of een leerling al dan niet een leerovereenkomst heeft afgesloten, maar aangezien het verschil tussen het aantal leerlingen in de theoriecomponent en de praktijkcomponent steeds kleiner wordt en in 1990 nog maar 1,5\% bedraagt (zie Ganga, 1992), kan toch een redelijke indicatie worden verkregen van verschuivingen in de verdeling van het aantal nieuw afgesloten leerovereenkomsten naar geslacht en naar leeftijd. Voor het vaststellen van eventuele verschuivingen is gebruik gemaakt van de bestanden voor de jaren 1988/'89 en 1991/'92.

\subsection{Opzet van het rapport}

De verdere opzet van dit rapport is als volgt. In hoofdstuk 2 wordt ingegaan op de ontwikkeling van de instroom in de primaire opleidingen. Daarbij wordt aandacht besteed aan zowel de historische als de toekomstige ontwikkelingen. In dit hoofdstuk wordt eerst een beeld gegeven van de ontwikkelingen van de instroom naar vooropleiding, geslacht en leeftijd. Daarna wordt 
ingegaan op de beleidsdoelstellingen van de verschillende landelijke organen, met name ten aanzien van de toekomstige leerlingeninstroom. Vervolgens wordt een beschrijving gegeven van het 'instroommodel' dat als basis dient voor de prognoses van de leerlingeninstroom, waarna een overzicht wordt gegeven van de verwachte instroom in de primaire opleidingen. Tenslotte worden deze instroomprognoses per landelijk orgaan geconfronteerd met de geplande leerlingeninstroom, waardoor inzicht wordt verkregen in de verwachte aanbodoverschotten en tekorten. Hoofdstuk 3 concentreert zich op de uitstroom uit de primaire opleidingen. In dit hoofdstuk wordt eerst de ontwikkeling van de uitstroom in het verleden in beeld gebracht. Daarna wordt ingegaan op het 'uitstroommodel' op basis waarvan prognoses zijn opgesteld van de verwachte gediplomeerde uitstroom. Daarbij wordt ook uitvoerig aandacht besteed aan de informatie over het interne rendement van de primaire opleidingen, die door de schattingen van het uitstroommodel wordt verkregen. Vervolgens wordt een overzicht gegeven van de verwachte gediplomeerde uitstroom per landelijk orgaan. In aanvulling op het in de hoofdstukken 2 en 3 beschreven basisscenario van de toekomstige in- en uitstroom van leerlingen, wordt in hoofdstuk 4 een viertal alternatieve beleidsscenario's in beeld gebracht, op basis waarvan toekomstige tekorten aan leerlingen voor de primaire opleidingen mogelijk zouden kunnen worden voorkomen. Tenslotte worden in hoofdstuk 5 de belangrijkste conclusies van deze studie kort samengevat. 


\section{DE INSTROOM IN DE PRIMAIRE OPLEIDINGEN}

\subsection{Inleiding}

In dit hoofdstuk zal een beeld worden geschetst van de ontwikkeling van de instroom in de primaire opleidingen. Daarbij gaat het zowel om de ontwikkeling van de instroom in het verleden als om prognoses van de voor de toekomst te verwachten instroom. De ontwikkeling van de instroom in het verleden wordt geanalyseerd vanuit drie verschillende invalshoeken: de vooropleiding, het geslacht en de leeftijd van de nieuwe leerlingen. Voor het prognosticeren van de toekomstige instroom in de primaire opleidingen zal een model worden geschat waarin de instroom wordt gerelateerd aan de 'beschikbare' uitstroom van leerlingen uit de relevante vooropleidingen in het initiële dagonderwijs. De met het geschatte model gegenereerde prognoses zullen worden gebruikt om na te gaan of het aanbod van leerlingen voor de opleidingen op het niveau van beginnend beroepsbeoefenaar al dan niet voldoende zal zijn om gedurende de prognoseperiode aan de vraag naar leerlingen op basis van het geplande aantal leer-arbeidsplaatsen te kunnen voldoen. Deze vraag-aanbod confrontatie zal voor alle 24 in deze studie onderscheiden landelijke organen voor het leerlingwezen worden uitgevoerd.

De opzet van dit hoofdstuk is als volgt. Eerst zal in paragraaf 2.2. worden ingegaan op de wijze waarop de instroom in de primaire opleidingen zich in het verleden heeft ontwikkeld. Daarbij wordt niet alleen de ontwikkeling van de totale omvang van de instroom besproken, maar ook de samenstelling van de instroom naar vooropleiding, geslacht en leeftijd. In paragraaf 2.3. wordt aangegeven in hoeverre de diverse landelijke organen doelstellingen ten aanzien van de toekomstige in- en uitstroom hebben geformuleerd. Paragraaf 2.4. beschrijft het te schatten instroommodel. Paragraaf 2.5. geeft een overzicht van de prognoseresultaten. In paragraaf 2.6. worden de verwachte instroom en het geplande aantal leer-arbeidsplaatsen met elkaar geconfronteerd, waardoor een indicatie van de te verwachten aanbodoverschotten of -tekorten wordt verkregen.

\subsection{De ontwikkeling van de instroom in het verleden}

In deze paragraaf zullen enkele historische trends in de ontwikkeling van de instroom in de primaire opleidingen van het leerlingwezen worden weergegeven. Daarbij wordt een achttal vooropleidingscategorieën onderscheiden:

- Lager Technisch Onderwijs met diploma (LTOMD);

- Lager Huishoud- en Nijverheidsonderwijs met diploma (LHNOMD);

- Lager Middenstandsonderwijs met diploma (LMOMD);

- Lager Economisch en Administratief Onderwijs met diploma (LEAOMD);

- Middelbaar Algemeen Voortgezet Onderwijs met diploma (MAVOMD);

- Lager Technisch Onderwijs zonder diploma (LTOZD);

- overige traditionele vooropleidingen (LHNO, LMO, LEAO en MAVO) zonder diploma (OVTRADZD);

- overig onderwijs (OVO). 
De figuren 2.1. tot en met 2.7. laten zien dat de vrees voor een in de toekomst tekort schietend aanbod van leerlingen in het primaire leerlingwezen niet ongegrond is. Gezien de forse daling van de uitstroom uit de traditionele vooropleidingen in het initiële dagonderwijs ${ }^{5}$ in de periode 1978-1990, is het al enigszins verbazingwekkend dat men er in geslaagd is het aantal leerlingen dat met één van deze vooropleidingen is ingestroomd in de primaire opleidingen van het leerlingwezen vanaf het inzetten van de 'verdubbelingsoperatie' in 1982 sterk te doen stijgen. Als gevolg hiervan nadert bij alle traditionele vooropleidingen de jaarlijkse instroom in de primaire opleidingen van het leerlingwezen steeds dichter het totale aantal schoolverlaters in het desbetreffende jaar. In de jaren 1988-1990 is de instroom van leerlingen met een LTO-diploma zelfs groter dan het aantal gediplomeerde schoolverlaters van het LTO. Ditzelfde heeft zich bij het MAVO in 1989 voorgedaan. Het spreekt voor zich dat een dergelijke situatie niet structureel kan blijven voortbestaan. Het is weliswaar mogelijk om gedurende een bepaalde tijd leerlingen aan te trekken die reeds één of meerdere jaren geleden het dagonderwijs hebben verlaten, maar ook uit dit reservoir kan niet eindeloos worden geput. Dit maakt het van groot belang om na te gaan of het te verwachten toekomstige aanbod van leerlingen voor het leerlingwezen toereikend zal zijn om in de vraag naar leerlingen te kunnen voorzien en op welke wijze de eventuele tekorten zouden kunnen worden aangevuld.

Figuur 2.1. Ontwikkeling gediplomeerde uitstroom LTO versus ontwikkeling instroom gediplomeerden LTO in het primair leerlingwezen

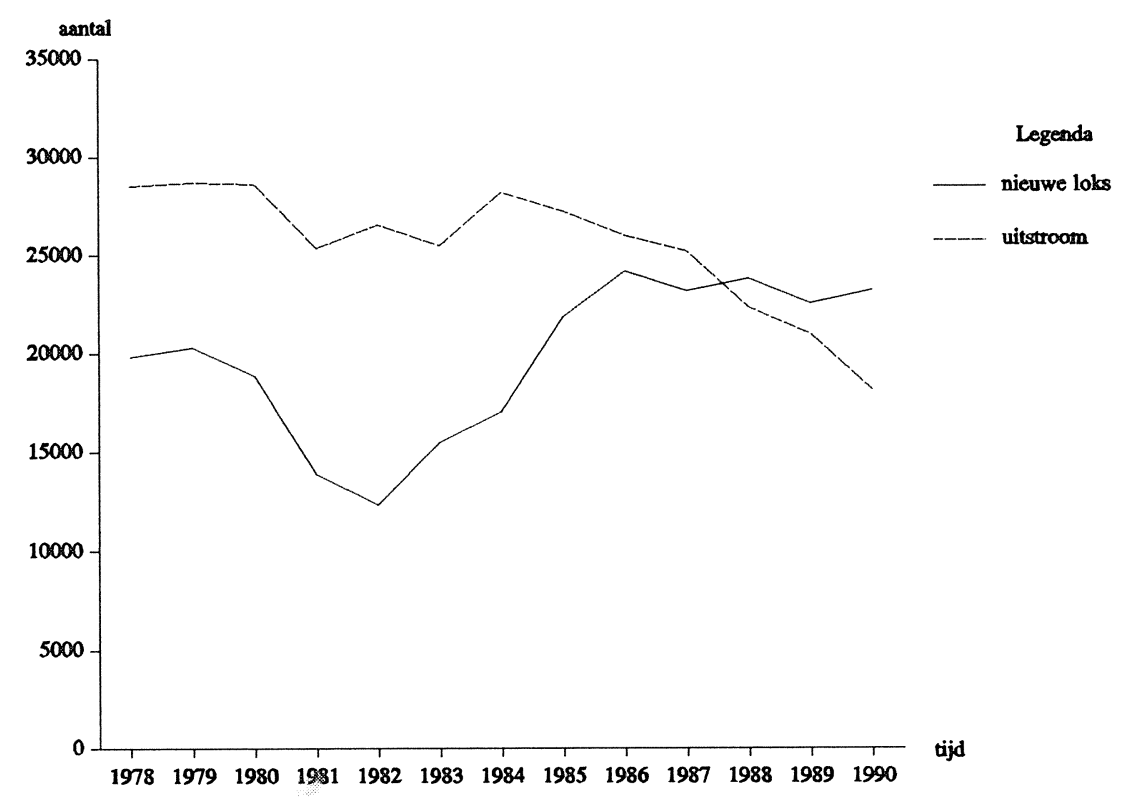

Bron: CBS/O\&W/CORO/ROA

5. Het gaat hier om de leerlingen die met de desbetreffende vooropleiding het initiële dagonderwijs verlaten. 
Figuur 2.2. Ontwikkeling gediplomeerde uitstroom LHNO versus ontwikkeling instroom gediplomeerden LHNO in het primair leerlingwezen

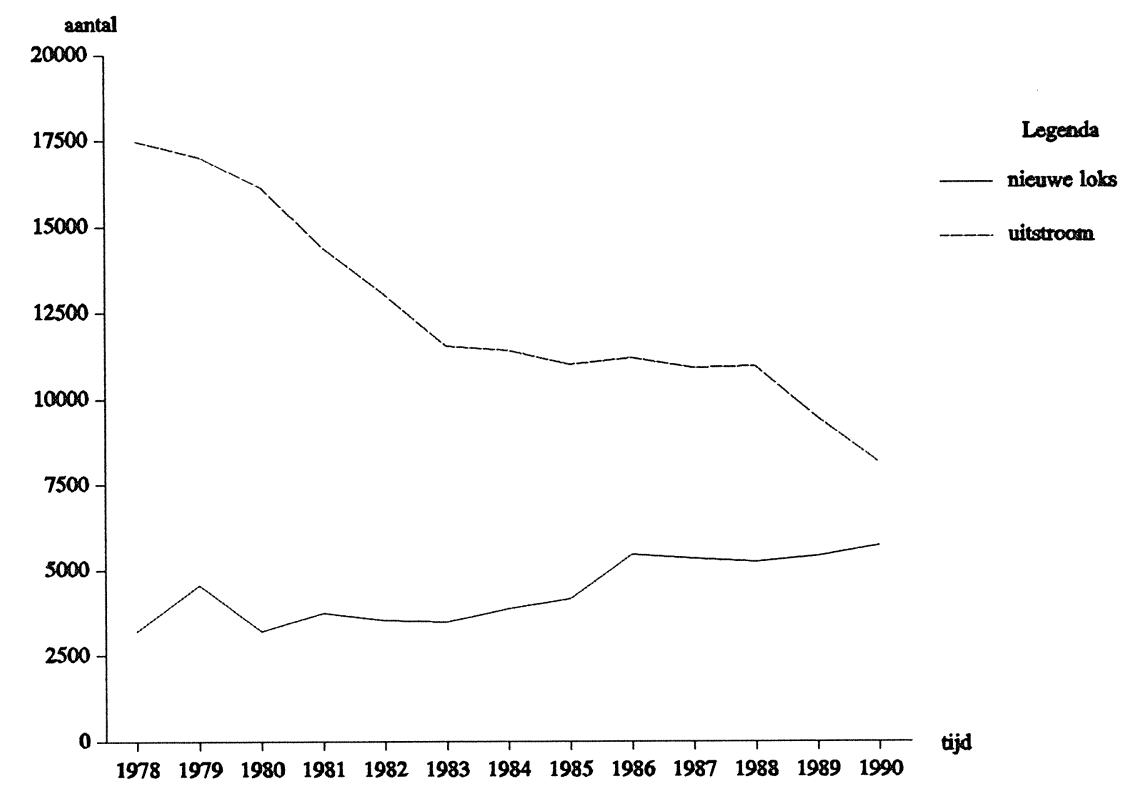

Bron: CBS/O\&W/CORO/ROA

Figuur 2.3. Ontwikkeling gediplomeerde uitstroom LMO versus ontwikkeling instroom gediplomeerden LMO in het primair leerlingwezen

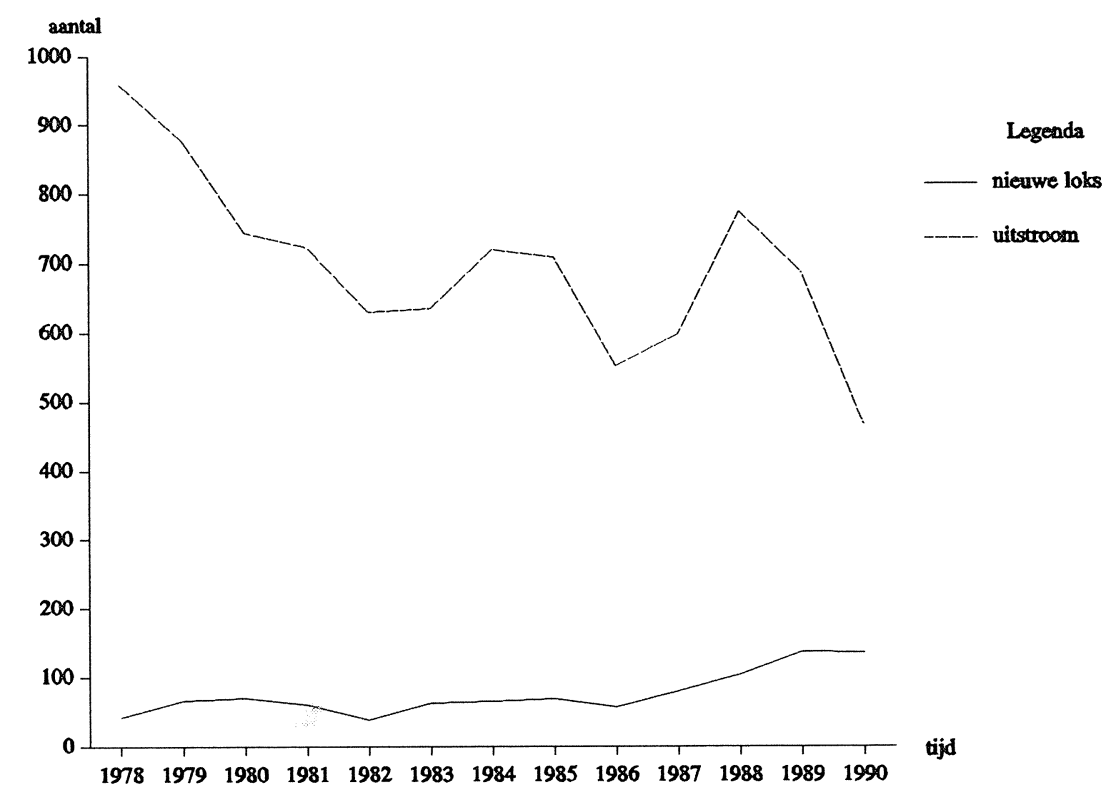

Bron: CBS/O\&W/CORO/ROA 
Figuur 2.4. Ontwikkeling gediplomeerde uitstroom LEAO versus ontwikkeling instroom gediplomeerden LEAO in het primair leerlingwezen

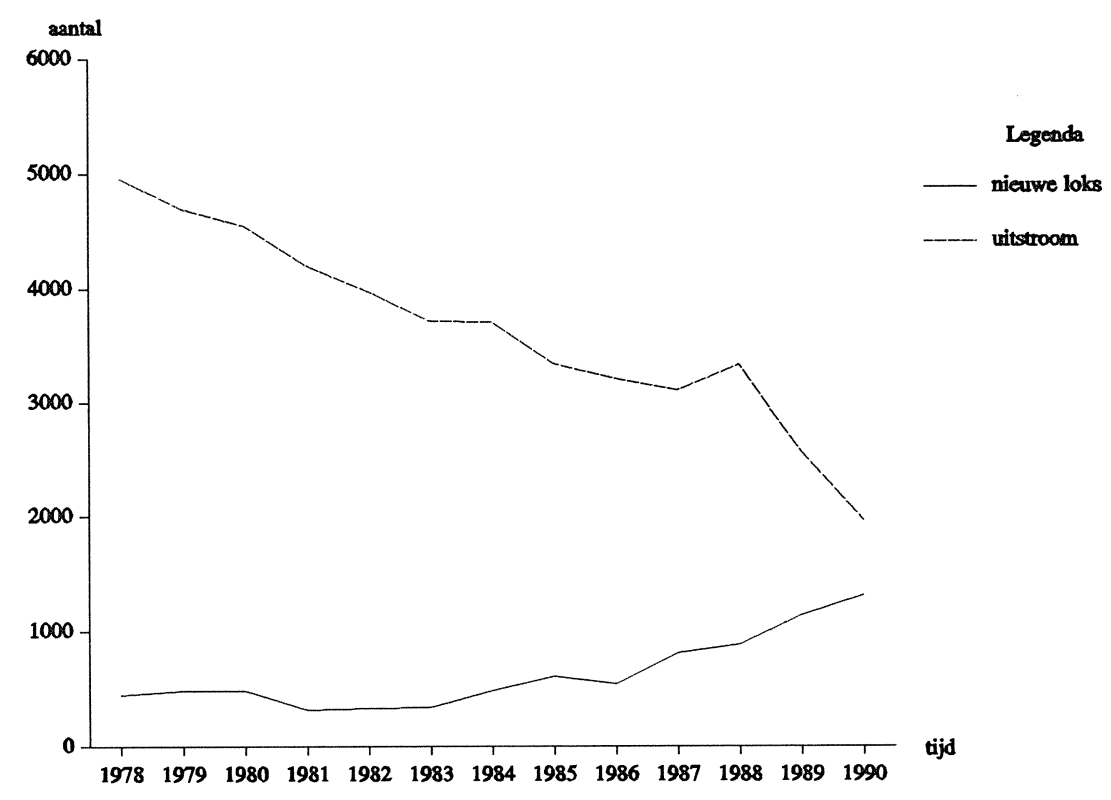

Bron: CBS/O\&W/CORO/ROA

Figuur 2.5. Ontwikkeling gediplomeerde uitstroom MAVO versus ontwikkeling instroom gediplomeerden MAVO in het primair leerlingwezen

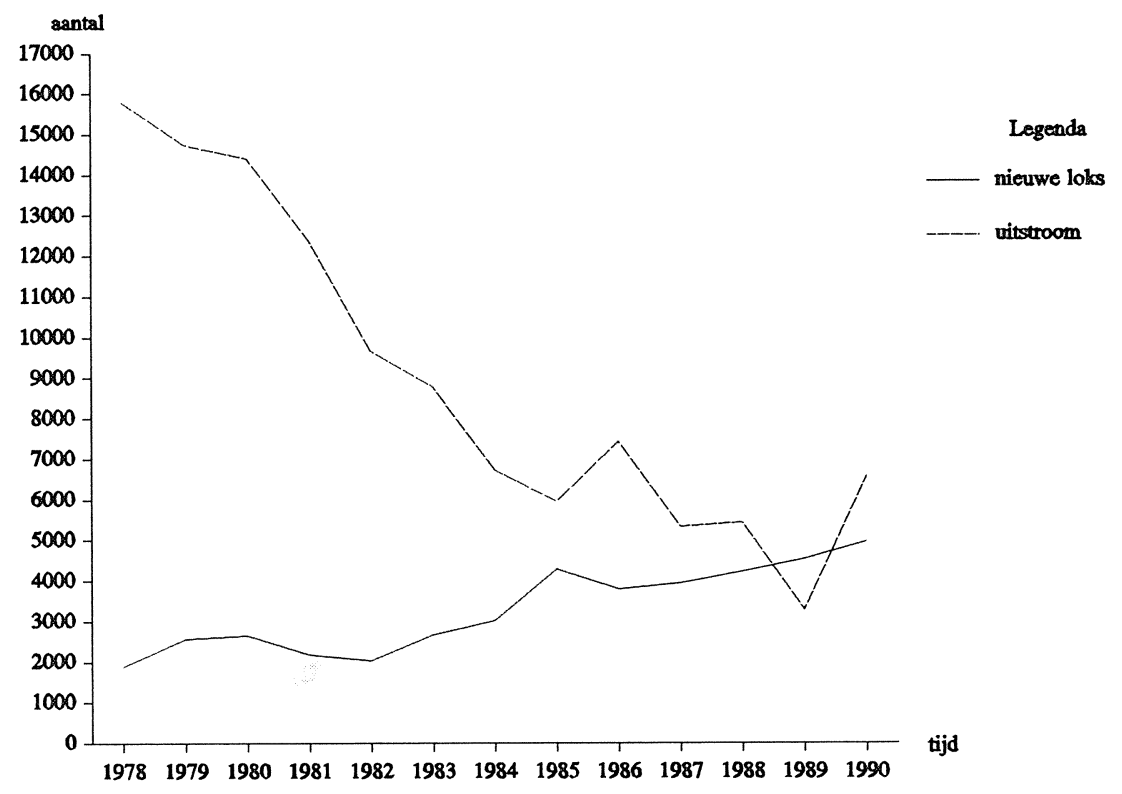

Bron: CBS/O\&W/CORO/ROA 
Figuur 2.6. Ontwikkeling ongediplomeerde uitstroom LTO versus ontwikkelng instroom ongediplomeerden LTO in het primair leerlingwezen

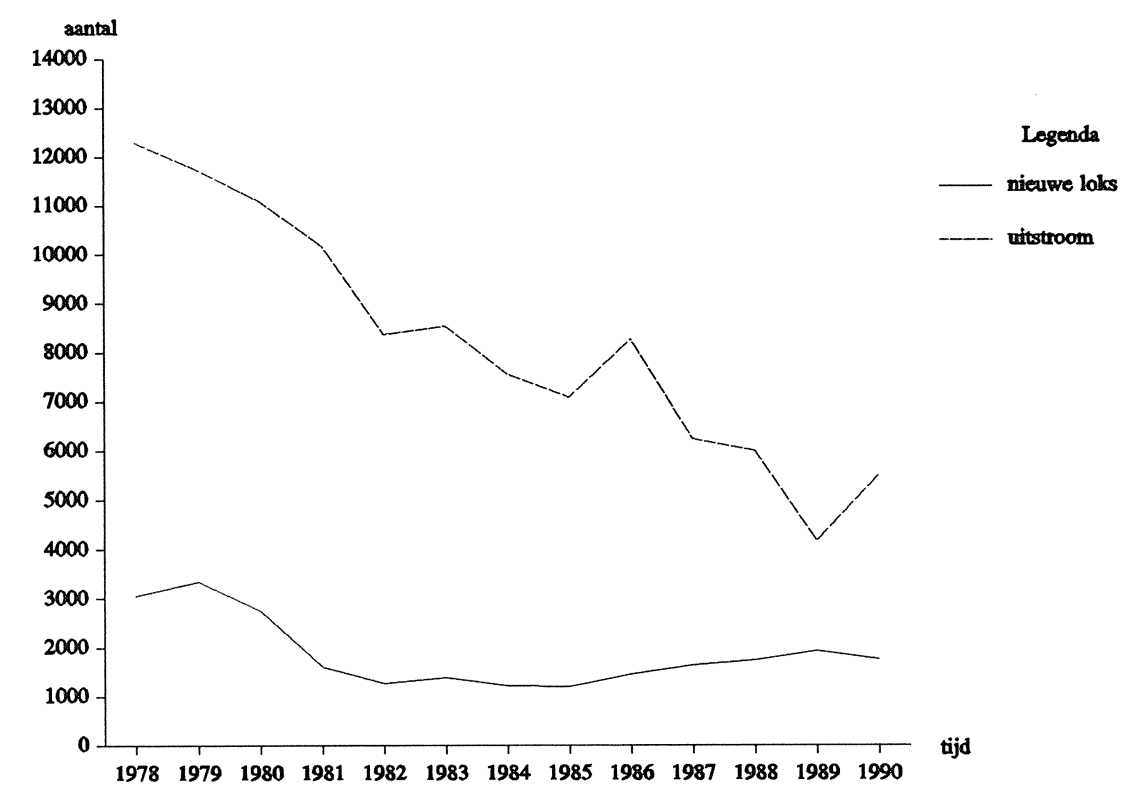

Bron: CBS/O\&W/CORO/ROA

Figuur 2.7. Ontwikkeling ongediplomeerde uitstroom overige traditionele vooropleidingen versus ontwikkeling instroom ongediplomeerden overige traditionele vooropleidingen in het primair leerlingwezen

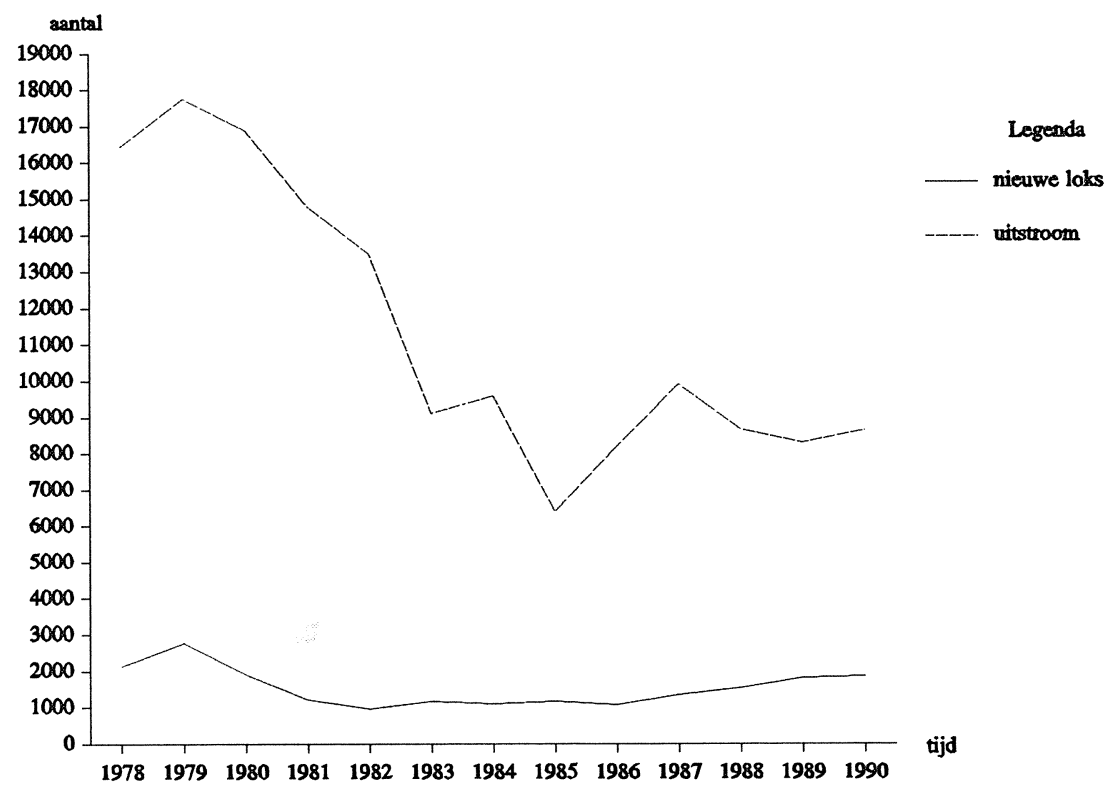

Bron: CBS/O\&W/CORO/ROA 
De in de loop van de jaren tachtig sterk gestegen instroom van leerlingen met een (voor)opleiding die tot de restcategorie 'overig onderwijs' behoort, wijst op een mogelijk nieuw recruteringspotentieel voor de primaire opleidingen. Al moet daarbij de kanttekening worden gemaakt dat de groei van de instroom met een niet-traditionele vooropleiding ${ }^{6}$ aan het eind van de jaren tachtig stagneert (zie figuur 2.8.).

Figuur 2.8. Ontwikkeling instroom overig onderwijs in het primair leerlingwezen

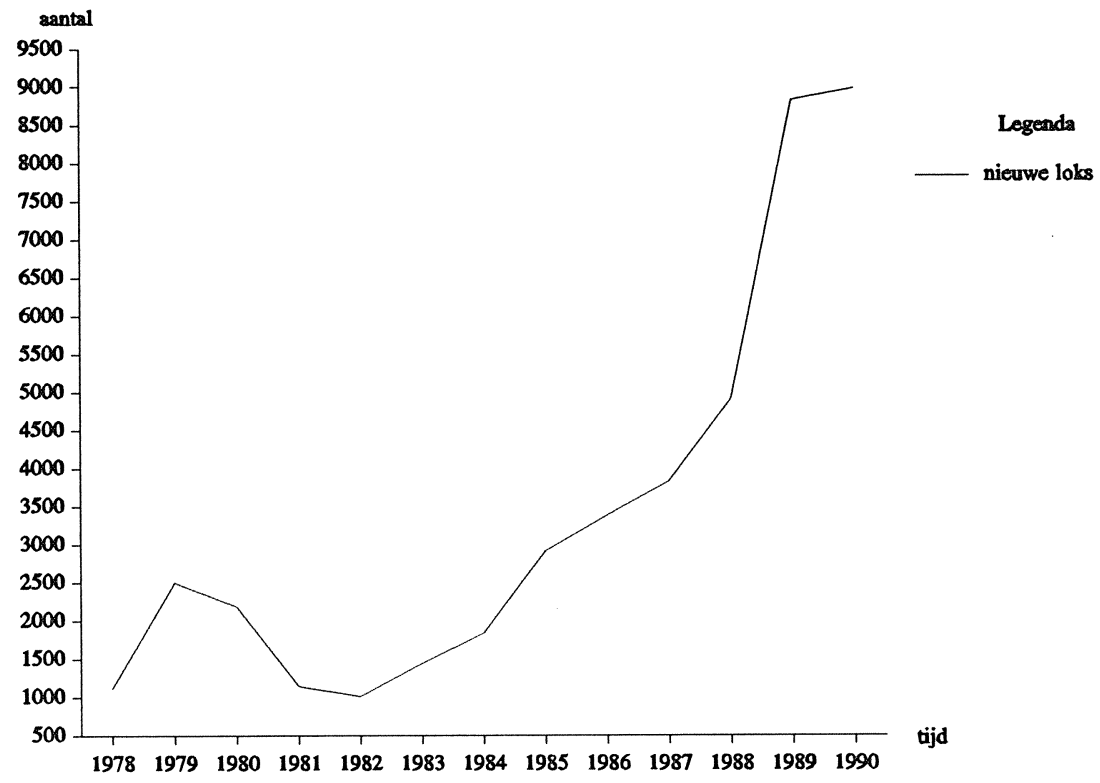

Bron: CBS/O\&W/CORO/ROA

Uit figuur 2.9. blijkt dat LTO-gediplomeerden in de periode 1978-1991 verreweg het grootste deel van de instroom in het primaire leerlingwezen vormen. Tabel B1 geeft op dit punt een cijfermatig overzicht (zie bijlage B). In 1991 ligt het aandeel van de LTO-gediplomeerden in de totale instroom van het primaire leerlingwezen echter maar liefst $15 \%$-punten lager dan in 1978. Met name na 1986 heeft zich een sterke daling ingezet die in hoge mate is gecompenseerd door de stijging van het instroomaandeel van de niet-traditionele vooropleidingen. Het instroomaandeel van leerlingen met een LHNO-diploma bereikt in 1982 een hoogtepunt met $16,4 \%$. Sindsdien beweegt het aandeel zich tussen de $11 \%$ en $14 \%$, waarbij

6. Strikt genomen wordt ook het Lager Agrarisch Onderwijs (LAO) tot het 'overig onderwijs' gerekend. Het LAO-aandeel is echter zo gering dat de termen 'overig onderwijs' en 'niet-traditionele vooropleidingen' door elkaar zullen worden gebruikt. Omdat het bij de niet-traditionele vooropleidingen vooral om het Hoger Algemeen Voortgezet Onderwijs (HAVO) en het Middelbaar Beroepsonderwijs (MBO) gaat, zullen ook deze laatste benamingen als synoniemen voor overig onderwijs worden gebruikt. Daarnaast moet worden opgemerkt dat de categorie 'overig onderwijs' zowel uit gediplomeerden als uit ongediplomeerden bestaat. 
zich overigens na 1986 een dalende tendens lijkt af te tekenen. De gediplomeerden van de economisch-administratieve opleidingen op LBO-niveau (LMO en LEAO) vormen een relatief klein deel van de instroom in de primaire opleidingen. Hun aandeel kent een maximum van $3 \%$ in 1990. Van 1978 tot 1985 vertoont het instroomaandeel van diplomabezitters van het MAVO een voortdurende stijging (van 5,9\% naar 11,8\%). Daarna schommelt het aandeel rond de $10 \%$. Het instroomaandeel van ongediplomeerde LBO- en MAVO-leerlingen daalt in de periode 1979-1986 van bijna $17 \%$ naar circa $6 \%$. Na 1986 loopt het aandeel van deze ongeschoolde LBO- en MAVO-ers in de totale instroom van het primaire leerlingwezen weer langzaam op. Dit langzame herstel staat echter in schril contrast met de groei van het instroomaandeel van de niet-traditionele vooropleidingen, waarvan het aandeel sinds 1986 ruimschoots is verdubbeld.

Figuur 2.9. Verdeling van de instroom in het primaire leerlingwezen naar vooropleiding, $1978-1991^{*}$

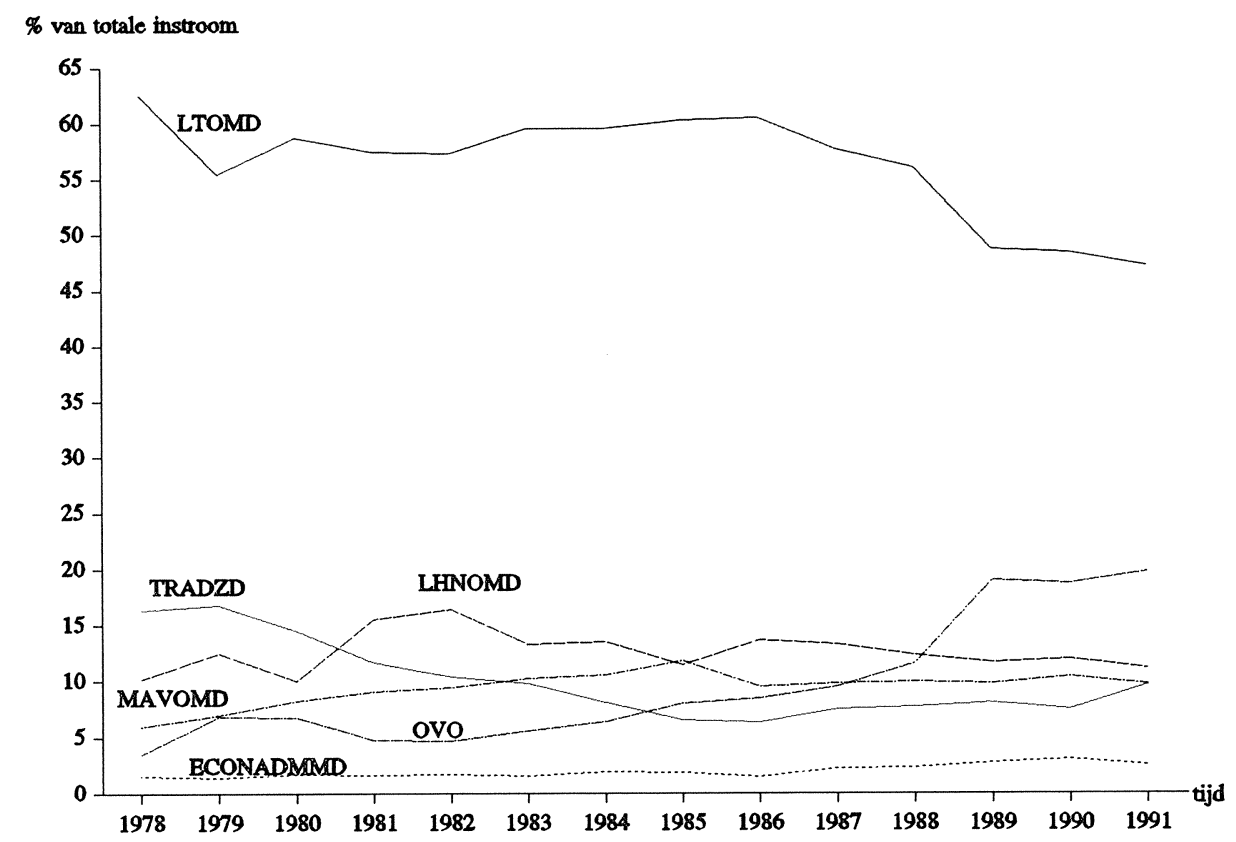

\section{Bron: CBS/O\&W/CORO/ROA}

* In de figuur zijn de categorieën 'LMO met diploma' en 'LEAO met diploma' samengevoegd tot de categorie 'economisch-administratief met diploma (ECONADMMD)'. De categorieën 'LTO zonder diploma' en 'overige traditionele vooropleidingen zonder diploma' zijn samengevoegd tot de categorie 'traditionele vooropleidingen zonder diploma (TRADZD)'.

\section{De ontwikkeling van de instroom naar vooropleiding en orgaan}

In de tabellen 2.1., 2.2. en 2.3. wordt voor elk van de acht onderscheiden vooropleidingen weergegeven hoe in de jaren 1978, 1985 en 1991 de instroom in de primaire opleidingen van het leerlingwezen over de landelijke opleidingsorganen is verdeeld. Op deze wijze kan een indicatie worden verkregen van de marktpositie van de diverse organen met betrekking tot de 
verschillende instroomcategorieën van het leerlingwezen. Uit de tabellen blijkt dat er in de loop van de jaren tachtig belangrijke verschuivingen zijn opgetreden in het aandeel van de verschillende organen in de instroom vanuit de diverse vooropleidingen. Zo weet de SVB (bouwbedrijf) in 1978 nog het grootste aantal LTO-gediplomeerden te trekken. In 1985 heeft daarentegen de VEV (elektrotechniek) het grootste aandeel in de relatief omvangrijke instroom van leerlingen met een LTO diploma. In 1991 neemt de SOM (metaal) deze positie over.

Tabel 2.1. Instroom in het primaire leerlingwezen per vooropleiding naar landelijk orgaan, 1978

\begin{tabular}{|c|c|c|c|c|c|c|c|c|}
\hline $\begin{array}{l}\text { Landelijk } \\
\text { orgaan }\end{array}$ & $\begin{array}{c}\text { LTOMD } \\
\%\end{array}$ & $\begin{array}{c}\text { LHNOMD } \\
\%\end{array}$ & $\begin{array}{c}\text { LMOMD } \\
\%\end{array}$ & $\begin{array}{c}\text { LEAOMD } \\
\%\end{array}$ & $\begin{array}{c}\text { MAVOMD } \\
\%\end{array}$ & $\begin{array}{r}\text { LTOZD } \\
\%\end{array}$ & $\begin{array}{c}\text { OVTRADZD } \\
\%\end{array}$ & $\begin{array}{c}\text { OVo } \\
\%\end{array}$ \\
\hline OVD & 0,6 & 31,9 & 3,6 & 19,8 & 4,8 & 2,6 & 20,0 & 4,0 \\
\hline ECABO & 0,1 & 6,3 & 2,8 & 16,4 & 14,0 & 0,1 & 2,6 & 1,5 \\
\hline SLW & 0,8 & 0,2 & 0,0 & 1,2 & 0,9 & 0,8 & 0,7 & 0,6 \\
\hline SOM & 15,9 & 0,0 & 2,4 & 4,0 & 5,9 & 6,0 & 2,0 & 7,4 \\
\hline SVB & 17,5 & 0,0 & 0,0 & 1,8 & 4,4 & 13,0 & 3,0 & 5,2 \\
\hline SVS & 4,0 & 0,0 & 1,4 & 0,8 & 1,7 & 5,2 & 1,6 & 2,1 \\
\hline INNOVAM & 14,9 & 0,0 & 9,5 & 7,9 & 7,8 & 12,0 & 4,9 & 8,4 \\
\hline VBOB & 1,1 & 0,0 & 1,1 & 0,0 & 0,0 & 3,0 & 0,1 & 3,2 \\
\hline VEV & 14,6 & 0,0 & 2,9 & 3,0 & 3,8 & 3,5 & 1,5 & 6,9 \\
\hline SVGB & 0,3 & 0,0 & 2,2 & 0,9 & 1,3 & 0,1 & 0,4 & 1,8 \\
\hline GOC & 2,6 & 0,1 & 10,5 & 7,6 & 7,8 & 3,7 & 3,3 & 7,6 \\
\hline VOC (conf) & 0,0 & 3,5 & 0,0 & 0,2 & 0,2 & 0,0 & 4,3 & 0,5 \\
\hline SVH & 8,0 & 3,2 & 4,1 & 11,2 & 11,9 & 12,4 & 6,4 & 7,3 \\
\hline VAS & 0,0 & 0,3 & 0,0 & 0,5 & 0,3 & 0,1 & 0,8 & 0,5 \\
\hline VAPRO & 1,0 & 0,0 & 3,9 & 1,1 & 3,6 & 1,1 & 1,2 & 7,9 \\
\hline OVDB & 0,0 & 37,1 & 8,2 & 0,3 & 0,5 & 0,1 & 7,1 & 11,1 \\
\hline SBW & 1,4 & 0,0 & 0,0 & 2,8 & 2,7 & 5,2 & 2,3 & 1,9 \\
\hline VOC (car) & 2,0 & 0,0 & 0,0 & 0,8 & 1,1 & 2,5 & 0,4 & 0,5 \\
\hline BETEX & 0,1 & 0,0 & 0,0 & 1,2 & 0,5 & 0,4 & 0,3 & 0,4 \\
\hline SH\&M & 3,5 & 0,1 & 3,0 & 1,5 & 2,2 & 5,5 & 1,3 & 2,5 \\
\hline SVEB & 2,3 & 0,1 & 7,1 & 2,5 & 2,1 & 3,8 & 0,7 & 2,1 \\
\hline SVK & 0,0 & 16,0 & 1,0 & 0,4 & 9,1 & 0,1 & 23,7 & 4,9 \\
\hline SVO & 1,7 & 1,2 & 35,0 & 13,0 & 10,1 & 10,6 & 9,7 & 8,9 \\
\hline SOI & 7,6 & 0,0 & 1,4 & 1,0 & 3,5 & 8,1 & 1,6 & 2,7 \\
\hline Totaal & 100 & 100 & 100 & 100 & 100 & 100 & 100 & 100 \\
\hline
\end{tabular}

Bron: $\mathrm{CBS} / \mathrm{O} \&$ W/CORO/ROA

Zowel in 1978 als in 1985 en 1991 gaat het grootste deel van de instroom van LHNOgediplomeerden naar de OVDB (verzorgende en dienstverlenende beroepen). De SVO (vleessector) is in de jaren 1978 en 1985 het belangrijkste orgaan voor de overigens kleine groep instromers met een LMO-diploma. In 1991 is deze rol echter overgenomen door de OVD (distributie). Ten opzichte van 1978 is het aandeel van dit orgaan in de instroom van LMOgediplomeerden bijna vertienvoudigd. Ook de ECABO (economische en administratieve 
beroepen) en de SVK (kappersbedrijf) hebben hun aandeel in de instroom van leerlingen met een LMO-diploma fors zien toenemen, waarbij de stijging van het ECABO-aandeel zich met name in de periode 1978-1985 heeft voorgedaan, terwijl het SVK-aandeel juist in de periode 1985-1991 sterk is gestegen. In 1991 ziet de OVD ook het grootste aantal LEAO-gediplomeerden binnen komen, een positie die het reeds in 1978 innam, maar in 1985 af moest staan aan de ECABO. Evenals bij de LMO-gediplomeerden is ook het SVK-aandeel in de instroom van LEAOgediplomeerden sterk gestegen.

Tabel 2.2. Instroom in het primaire leerlingwezen per vooropleiding naar landelijk orgaan, 1985

\begin{tabular}{|c|c|c|c|c|c|c|c|c|}
\hline $\begin{array}{l}\text { Landelijk } \\
\text { orgaan }\end{array}$ & $\begin{array}{c}\text { LTOMD } \\
\%\end{array}$ & $\begin{array}{c}\text { LHNOMD } \\
\%\end{array}$ & $\begin{array}{c}\text { LMOMD } \\
\%\end{array}$ & $\begin{array}{c}\text { LEAOMD } \\
\%\end{array}$ & $\begin{array}{c}\text { MAVOMD } \\
\%\end{array}$ & $\begin{array}{c}\text { LTOZD } \\
\%\end{array}$ & $\begin{array}{c}\text { OVTRADZD } \\
\%\end{array}$ & $\begin{array}{c}\text { Ovo } \\
\%\end{array}$ \\
\hline OVD & 0,6 & 18,2 & 15,0 & 23,1 & 5,2 & 2,7 & 12,8 & 3,6 \\
\hline ECABO & 0,7 & 3,6 & 12,2 & 33,9 & 15,3 & 1,2 & 8,8 & 19,3 \\
\hline SLW & 2,2 & 0,0 & 0,0 & 0,3 & 0,8 & 0,1 & 0,0 & 0,1 \\
\hline SOM & 15,5 & 0,1 & 5,5 & 3,2 & 8,6 & 9,4 & 4,0 & 11,5 \\
\hline SVB & 12,3 & 0,0 & 0,0 & 0,1 & 0,5 & 4,9 & 0,9 & 2,3 \\
\hline SVS & 3,5 & 0,0 & 2,8 & 0,6 & 1,1 & 8,2 & 1,8 & 1,3 \\
\hline INNOVAM & 9,8 & 0,1 & 7,0 & 2,6 & 5,8 & 10,3 & 3,5 & 5,1 \\
\hline VBOB & 1,2 & 0,3 & 0,0 & 0,0 & 0,1 & 3,2 & 0,1 & 0,5 \\
\hline VEV & 23,8 & 0,5 & 7,4 & 2,5 & 11,2 & 11,8 & 4,8 & 23,1 \\
\hline SVGB & 0,1 & 0,2 & 2,1 & 0,8 & 1,1 & 0,1 & 0,6 & 1,2 \\
\hline GOC & 2,2 & 0,3 & 5,1 & 4,3 & 5,2 & 3,1 & 3,6 & 5,5 \\
\hline VOC (conf) & 0,0 & 5,3 & 0,0 & 1,3 & 0,4 & 0,1 & 4,7 & 1,2 \\
\hline SVH & 6,2 & 2,8 & 7,7 & 5,2 & 5,9 & 10,2 & 5,4 & 5,4 \\
\hline VAS & 0,1 & 0,5 & 0,0 & 1,0 & 0,3 & 0,3 & 1,0 & 0,2 \\
\hline VAPRO & 2,4 & 0,0 & 0,0 & 1,3 & 4,5 & 1,9 & 1,8 & 3,9 \\
\hline OVDB & 0,1 & 35,5 & 0,0 & 0,9 & 0,6 & 0,1 & 5,0 & 0,9 \\
\hline SBW & 2,6 & 0,0 & 0,0 & 1,2 & 2,1 & 6,0 & 1,3 & 1,7 \\
\hline VOC (car) & 2,8 & 0,0 & 5,4 & 1,2 & 1,5 & 5,1 & 1,8 & 1,4 \\
\hline BETEX & 0,3 & 0,2 & 0,0 & 0,5 & 0,4 & 0,3 & 0,4 & 0,5 \\
\hline SH\&M & 2,7 & 0,2 & 2,5 & 1,2 & 0,8 & 3,0 & 1,0 & 2,0 \\
\hline SVEB & 2,4 & 0,1 & 3,7 & 1,1 & 1,0 & 3,6 & 1,4 & 1,1 \\
\hline SVK & 0,4 & 27,9 & 1,7 & 4,8 & 21,1 & 1,0 & 29,3 & 2,0 \\
\hline Svo & 1,8 & 4,1 & 21,0 & 7,1 & 4,1 & 5,8 & 4,2 & 3,3 \\
\hline SOI & 6,2 & 0,0 & 1,0 & 1,7 & 2,5 & 7,6 & 1,7 & 2,8 \\
\hline Totaal & 100 & 100 & 100 & 100 & 100 & 100 & 100 & 100 \\
\hline
\end{tabular}

Bron: $\mathrm{CBS} / \mathrm{O} \& \mathrm{~W} / \mathrm{CORO} / \mathrm{ROA}$

De ECABO neemt in 1978 het grootste deel van de instroom van MAVO-gediplomeerden voor haar rekening. In 1985 en 1991 gaan de meeste nieuwe leerlingen met een MAVO-diploma echter naar de SVK. Daarnaast heeft de OVD zijn instroomaandeel in de MAVO-gediplomeerden sterk vergroot. Deze toename is vooral in de periode 1985-1991 gerealiseerd. De ongediplomeerde LTO-instromers volgen het beeld van de gediplomeerde LTO-ers met dien 
verstande dat in 1991 niet het grootste deel naar de SOM gaat, maar naar de SVB. De SVK is erg in trek bij de ongediplomeerde instroom van het LHNO, LMO, LEAO en MAVO. Verder valt op dat het instroomaandeel van de ECABO in deze groep fors is gestegen, waarbij de stijging geconcenteerd is in de periode 1978-1985. In 1978 trekt de OVDB het grootste aantal nieuwe leerlingen met een niet-traditionele vooropleiding. Door een forse toename van haar instroomaandeel tussen 1978 en 1985 neemt de VEV deze positie over en is zij ook in 1991 het belangrijkste orgaan voor de niet-traditionele vooropleidingen. Daarnaast vertoont het ECABOaandeel in de niet-traditionele vooropleidingen een flinke stijging ten opzichte van 1978 . Ten opzichte van 1985 is het ECABO-belang echter al weer sterk gedaald.

Tabel 2.3. Instroom in het primaire leerlingwezen per vooropleiding naar landelijk orgaan, 1991

\begin{tabular}{|c|c|c|c|c|c|c|c|c|}
\hline $\begin{array}{l}\text { Landelijk } \\
\text { orgaan }\end{array}$ & $\begin{array}{c}\text { LTOMD } \\
\%\end{array}$ & $\begin{array}{c}\text { LHNOMD } \\
\%\end{array}$ & $\begin{array}{c}\text { LMOMD } \\
\%\end{array}$ & $\begin{array}{r}\text { LEAOMD } \\
\%\end{array}$ & $\begin{array}{c}\text { MAVOMD } \\
\%\end{array}$ & $\begin{array}{c}\text { LTOZD } \\
\%\end{array}$ & $\begin{array}{c}\text { OVTRADZD } \\
\%\end{array}$ & $\begin{array}{c}\text { OVo } \\
\%\end{array}$ \\
\hline OVD & 2,2 & 25,3 & 33,7 & 29,5 & 11,5 & 4,8 & 17,9 & 8,2 \\
\hline ECABO & 0,7 & 4,9 & 10,2 & 25,7 & 9,2 & 1,3 & 9,9 & 9,4 \\
\hline SLW & 4,7 & 0,2 & 0,0 & 0,9 & 1,1 & 0,8 & 0,3 & 0,7 \\
\hline SOM & 15,0 & 0,3 & 2,4 & 1,3 & 7,2 & 7,2 & 1,5 & 9,5 \\
\hline SVB & 11,6 & 0,1 & 2,9 & 2,5 & 3,1 & 10,7 & 2,5 & 5,3 \\
\hline SVS & 4,2 & 0,1 & 1,5 & 2,1 & 1,7 & 9,7 & 2,6 & 2,3 \\
\hline INNOVAM & 10,8 & 0,1 & 4,8 & 1,7 & 6,2 & 7,3 & 2,5 & 6,2 \\
\hline VBOB & 0,9 & 0,2 & 1,5 & 0,3 & 0,9 & 3,9 & 0,2 & 0,5 \\
\hline VEV & 13,8 & 0,2 & 1,0 & 1,6 & 8,1 & 7,9 & 3,4 & 19,5 \\
\hline SVGB & 0,3 & 0,2 & 0,5 & 0,7 & 2,1 & 0,2 & 0,4 & 2,1 \\
\hline GOC & 2,2 & 0,6 & 3,8 & 3,9 & 6,6 & 2,3 & 2,2 & 4,1 \\
\hline VOC (conf) & 0,1 & 3,6 & 0,0 & 0,3 & 0,4 & 0,6 & 3,4 & 1,1 \\
\hline SVH & 6,4 & 3,3 & 6,4 & 5,3 & 7,8 & 7,0 & 5,2 & 6,3 \\
\hline VAS & 0,0 & 0,2 & 0,0 & 0,1 & 0,0 & 0,2 & 0,2 & 0,1 \\
\hline VAPRO & 5,9 & 0,7 & 0,5 & 0,2 & 1,3 & 3,0 & 0,4 & 1,2 \\
\hline OVDB & 0,3 & 36,7 & 2,7 & 0,4 & 2,0 & 0,0 & 12,6 & 2,4 \\
\hline SBW & 3,4 & 0,0 & 0,0 & 1,3 & 2,2 & 5,0 & 0,8 & 1,6 \\
\hline VOC (car) & 2,7 & 0,1 & 1,7 & 0,7 & 1,4 & 4,3 & 0,9 & 1,7 \\
\hline BETEX & 0,3 & 0,1 & 0,3 & 0,5 & 0,5 & 0,7 & 0,3 & 0,7 \\
\hline SH\&M & 3,7 & 0,2 & 0,6 & 0,7 & 1,2 & 3,8 & 0,7 & 2,0 \\
\hline SVEB & 2,3 & 0,1 & 0,0 & 0,3 & 1,4 & 2,2 & 0,4 & 0,8 \\
\hline SVK & 0,7 & 18,8 & 7,1 & 13,7 & 16,7 & 3,3 & 25,9 & 6,6 \\
\hline SVO & 1,8 & 3,9 & 15,4 & 4,9 & 4,3 & 5,9 & 3,3 & 2,5 \\
\hline SOI & 5,8 & 0,2 & 3,0 & 1,4 & 3,2 & 7,7 & 2,3 & 5,1 \\
\hline Totaal & 100 & 100 & 100 & 100 & 100 & 100 & 100 & 100 \\
\hline
\end{tabular}

Bron: CBS/O\&W/CORO/ROA

Wanneer we de instroomcijfers vanuit een andere invalshoek bekijken, kan een indruk worden verkregen van de verschuivingen die zijn opgetreden in de samenstelling van de instroom van leerlingen bij een bepaald orgaan. Uit de tabellen B.2. tot en met B.4. (zie bijlage B) blijkt dat 
vrijwel alle organen in de loop der tijd een steeds groter deel van de instroom in de primaire opleidingen putten uit de niet-traditionele vooropleidingen, met name het HAVO en het MBO. De enige uitzondering hierop vormt de VAPRO (procesindustrie) die in 1991 nog slechts $7 \%$ van de nieuwe leerlingen uit het overig onderwijs aantrekt, terwijl dat in 1978 nog ruim $20 \%$ was. Buiten de VAPRO zijn er slechts 5 organen waarbij de stijging van het instroomaandeel van de niet-traditionele vooropleidingen tussen 1978 en 1991 minder dan 10\%-punten bedraagt. Dit zijn de SLW (wegvervoer), de VBOB (banketbakkersbranche), de OVDB, de SBW (weg- en waterbouw) en de SVEB (bakkersbedrijf), al is er bij de SBW en de SVEB wel een verdubbeling van het instroomaandeel van leerlingen met een HAVO- of een MBO-opleiding opgetreden.

Bij de ECABO, de SVGB (gezondheidstechnische beroepen), de VAS (schoen- en lederwarenindustrie) en de BETEX (textielindustrie) is de stijging van het instroomaandeel van de niet-traditionele vooropleidingen dusdanig groot, dat deze opleidingen in 1991 de belangrijkste categorie vormen waaruit de nieuwe leerlingen in de primaire opleidingen van deze organen afkomstig zijn? ${ }^{7}$. Koploper is wat dit betreft de SVGB, die in 1991 meer dan de helft van de totale instroom van leerlingen uit deze niet-traditionele vooropleidingen recruteert.

Bij het merendeel van de organen maken de LTO-gediplomeerden echter nog steeds het grootste deel van de instroom uit. Wel richten ook deze organen zich, met uitzondering van de VAPRO die een steeds groter deel van de instroom uit het LTO recruteert, in toenemende mate op de niet-traditionele vooropleidingen. Zoals gezegd, hebben ook de SLW en de VBOB tussen 1978 en 1991 geen grote vooruitgang geboekt in het aantrekken van leerlingen uit deze niettraditionele opleidingen. De $V B O B$ noteert daarentegen wel een forse stijging van het instroomaandeel van MAVO-gediplomeerden. Verder valt op dat van de organen die traditioneel onder LTO-gediplomeerden werven, de SVO ten opzichte van 1978 niet alleen een relatief groter deel van de instroom uit het overig onderwijs heeft gehaald, maar ook een sterke toename van het instroomaandeel van LHNO-gediplomeerden heeft gerealiseerd.

Voor de OVD, de VOC (confectietechniek), de OVDB en de SVK zijn de diplomabezitters van het LHNO van oudsher de belangrijkste groep waaruit nieuwe leerlingen voor de primaire opleidingen worden aangetrokken. Met uitzondering van de OVDB is echter ook bij deze organen het instroomaandeel van de niet-traditionele vooropleidingen in 1991 aanzienlijk groter dan in 1978 . Opvallend is dat de OVD en de VOC daarnaast het instroomaandeel van LTO-gediplomeerden hebben vergroot. Bovendien is bij de OVD ook nog eens een groter deel van de instroom in het bezit van een MAVO-diploma.

De ontwikkeling van de instroom naar geslacht en orgaan

Met behulp van de Opgave Van Leerlingwezen (OVL)-bestanden van het Ministerie van Onderwijs en Wetenschappen (zie ook paragraaf 1.4.) kan de samenstelling van de instroom in

7. Bij de ECABO werd de basis hiervoor reeds grotendeels gelegd in de periode 1978-1985. Bij de andere drie gebeurde dit tussen 1985 en 1991. 
de primaire opleidingen naar geslacht in beeld worden gebracht. Tabel 2.4. geeft hiervan een overzicht voor de verschillende landelijke organen in de jaren 1988 en 1991. Uit de tabel blijkt dat er in de periode 1988-1991 slechts geringe verschuivingen zijn opgetreden in de aandelen van mannen en vrouwen in de totale instroom van leerlingen in de primaire opleidingen. Opvallend genoeg is er daarbij per saldo zelfs sprake van een daling van het percentage vrouwen van $31 \%$ naar $29 \%$. Wel kan er in 1991 voor het eerst worden geconstateerd dat er bij alle organen vrouwelijke leerlingen voorkomen. In 1988 was dit nog niet het geval bij de SBW.

Tabel 2.4. Verdeling van de instroom per landelijk orgaan naar geslacht, 1988 en 1991

\begin{tabular}{|c|c|c|c|c|}
\hline \multirow{2}{*}{$\begin{array}{l}\text { Landelijk } \\
\text { orgaan }\end{array}$} & \multicolumn{2}{|c|}{1988} & \multicolumn{2}{|c|}{1991} \\
\hline & $\begin{array}{r}\operatorname{man} \\
\%\end{array}$ & $\begin{array}{r}\text { vrouw } \\
\%\end{array}$ & $\begin{array}{c}\operatorname{man} \\
\%\end{array}$ & $\begin{array}{r}\text { vrouw } \\
\%\end{array}$ \\
\hline OVD & 31 & 69 & 41 & 59 \\
\hline ECABO & 38 & 62 & 25 & 75 \\
\hline SLW & 94 & 6 & 93 & 7 \\
\hline SOM & 96 & 4 & 97 & 3 \\
\hline SVB & 98 & 2 & 98 & 2 \\
\hline SVS & 97 & 3 & 97 & 3 \\
\hline INNOVAM & 98 & 2 & 97 & 3 \\
\hline VBOB & 82 & 18 & 79 & 21 \\
\hline VEV & 98 & 2 & 97 & 3 \\
\hline SVGB & 63 & 37 & 49 & 51 \\
\hline GOC & 75 & 25 & 78 & 22 \\
\hline VOC (conf) & 7 & 93 & 12 & 88 \\
\hline SVH & 71 & 29 & 65 & 35 \\
\hline VAS & 33 & 67 & 27 & 73 \\
\hline VAPRO & 97 & 3 & 97 & 3 \\
\hline OVDB & 5 & 95 & 7 & 93 \\
\hline SBW & 100 & 0 & 99 & 1 \\
\hline VOC (car) & 99 & 1 & 96 & 4 \\
\hline BETEX & 95 & 5 & 86 & 14 \\
\hline SH\&M & 92 & 8 & 94 & 6 \\
\hline SVEB & 92 & 8 & 89 & 11 \\
\hline SVK & 8 & 92 & 7 & 93 \\
\hline SVO & 51 & 49 & 54 & 46 \\
\hline SOI & 98 & 2 & 98 & 2 \\
\hline Totaal & 69 & 31 & 71 & 29 \\
\hline
\end{tabular}

Bron: O\&W/ROA

In het algemeen is er duidelijk sprake van een tweedeling tussen enerzijds een groot aantal landelijke organen dat voor het overgrote deel mannen recruteert en anderzijds enkele organen die met name vrouwelijke leerlingen kennen. In het laatste geval gaat het om de OVDB en de SVK (93\% vrouwen), de VOC (confectietechniek, 88\% vrouwen), de ECABO (75\% vrouwen) 
en de VAS $(73 \% \text { vrouwen })^{8}$.

Een opvallende verschuiving, in de zin van een toename van het percentage mannen, doet zich voor bij de OVD (van $31 \%$ naar $41 \%$ ) en de VOC (confectietechniek, van $7 \%$ naar $12 \%$ ). In beide gevallen gaat het om landelijke organen die voor het merendeel vrouwen recruteren. Daarentegen is er sprake van een opvallende toename van het percentage vrouwen bij de SVGB (van $37 \%$ naar $51 \%$ ), de ECABO (van $62 \%$ naar $75 \%$ ), de BETEX (van $5 \%$ naar $14 \%$ ), de VAS (van $67 \%$ naar $73 \%$ ) en de SVH (horeca, van $29 \%$ naar $35 \%$ ). Bij de meeste op technische opleidingen gerichte organen, waarbij vrouwen slechts een miniem deel van de instroom uitmaken, valt er echter vrijwel geen verandering te constateren in het percentage vrouwen dat instroomt bij de primaire opleidingen.

\section{De ontwikkeling van de instroom naar leeftijd en orgaan}

Op basis van de OVL-bestanden kan ook een beeld worden geschetst van de leeftijdsverdeling van de instroom in de primaire opleidingen. Op deze wijze kan worden getraceerd in welke mate de verschillende landelijke organen er in slagen leerlingen te recruteren uit de oudere leeftijdsgroepen. Tabel 2.5. geeft hiervan een overzicht voor de jaren 1988 en 1991.

Uit de tabel blijkt dat het overgrote deel van de instroom tot de jongste leeftijdscategorie 15-22 jaar behoort (74\% in 1991). In dit beeld is in de periode 1988-1991 vrijwel geen verandering opgetreden. Er bestaan op dit punt echter grote verschillen tussen de diverse landelijke organen. Zo blijkt een tweetal organen (de VAS en de VAPRO) in 1991 zelfs meer dan de helft van de leerlingen uit de oudste leeftijdscategorie (ouder dan 27 jaar) te recruteren. Bij deze beide organen is er samen met de OVDB ook sprake van de grootste toename van de instroom uit de oudste leeftijdsgroep.

Daarentegen blijkt een aantal andere landelijk organen vrijwel alleen jongeren (15-22 jaar) aan te trekken: SVK (97\%), VBOB (96\%), en SLW $(90 \%)^{9}$. Al met al is er bij 14 van de 24 onderscheiden landelijke organen sprake van een (doorgaans geringe) toename van het aantal instromers dat ouder is dan 27 jaar. Bij zes landelijke organen is er daarentegen sprake van een (geringe) daling van de instroom van ouderen.

8. Percentages voor 1991.

9. Percentages voor 1991. 
Tabel 2.5. Verdeling van de instroom per landelijk orgaan naar leeftijdsklasse, 1988 en 1991

\begin{tabular}{|c|c|c|c|c|c|c|}
\hline $\begin{array}{l}\text { Landelijk } \\
\text { orgaan }\end{array}$ & $\begin{array}{r}15-22 \\
\text { jaar } \\
\%\end{array}$ & $\begin{array}{r}1988 \\
23-27 \\
\text { jaar } \\
\%\end{array}$ & $\begin{array}{r}28+ \\
\text { jaar } \\
\%\end{array}$ & $\begin{array}{r}15-22 \\
\text { jaar } \\
\%\end{array}$ & $\begin{array}{r}1991 \\
23-27 \\
\text { jaar } \\
\%\end{array}$ & $\begin{array}{r}28+ \\
\text { jaar } \\
\%\end{array}$ \\
\hline OVD & 90 & 4 & 5 & 82 & 7 & 11 \\
\hline ECABO & 59 & 17 & 24 & 53 & 14 & 32 \\
\hline SLW & 94 & 4 & 3 & 90 & 5 & 5 \\
\hline SOM & 66 & 15 & 19 & 64 & 16 & 20 \\
\hline SVB & 86 & 7 & 7 & 84 & 9 & 7 \\
\hline SVS & 80 & 10 & 10 & 74 & 11 & 16 \\
\hline INNOVAM & 88 & 6 & 6 & 88 & 6 & 5 \\
\hline VBOB & 82 & 10 & 8 & 96 & 2 & 2 \\
\hline VEV & 68 & 18 & 15 & 68 & 18 & 15 \\
\hline SVGB & 70 & 21 & 9 & 56 & 32 & 11 \\
\hline GOC & 58 & 16 & 25 & 61 & 17 & 21 \\
\hline VOC (conf) & 69 & 11 & 20 & 72 & 11 & 18 \\
\hline SVH & 90 & 5 & 5 & 87 & 6 & 7 \\
\hline VAS & 53 & 16 & 31 & 39 & 7 & 54 \\
\hline VAPRO & 24 & 33 & 42 & 13 & 31 & 57 \\
\hline OVDB & 69 & 9 & 22 & 54 & 13 & 34 \\
\hline SBW & 92 & 5 & 3 & 83 & 11 & 6 \\
\hline VOC (car) & 90 & 4 & 6 & 88 & 5 & 7 \\
\hline BETEX & 32 & 35 & 33 & 25 & 46 & 29 \\
\hline SH\&M & 70 & 9 & 21 & 73 & 8 & 19 \\
\hline SVEB & 97 & 2 & 1 & 88 & 5 & 8 \\
\hline SVK & 96 & 3 & 1 & 97 & 2 & 1 \\
\hline svo & 96 & 4 & 1 & 89 & 8 & 2 \\
\hline sol & 76 & 12 & 13 & 73 & 13 & 13 \\
\hline Totaal & 75 & 11 & 14 & 74 & 11 & 15 \\
\hline
\end{tabular}

Bron: O\&W/ROA

\subsection{Beleidsdoelstellingen}

Om na te gaan in hoeverre de landelijke organen voor het leerlingwezen de toekomstige behoefte aan geschoolde arbeidskrachten hebben vertaald in beleidsdoelstellingen ten aanzien van de toekomstige instroom en het interne rendement, dan wel het jaarlijkse aantal geslaagden van de opleidingen in het leerlingwezen, is een korte schriftelijke enquête gehouden waarin naar de aanwezigheid van dergelijke streefcijfers werd gevraagd (zie bijlage C). Tevens werden in deze enquête enkele vragen gesteld over de beschikbaarheid van historische in- en uitstroomcijfers. Van de 24 in het onderzoek betrokken organen reageerden er in eerste instantie 16. Na een schriftelijk rappel werden nog eens 5 vragenlijsten ingevuld geretourneerd. Twee organen wensten niet mee te werken aan het onderzoek. Eén orgaan gaf geen enkele reactie. Uiteindelijk is derhalve van 21 van de 24 organen een ingevulde vragenlijst ontvangen. 
Tabel 2.6. Aanwezigheid van streefcijfers bij de landelijke organen voor het leerlingwezen

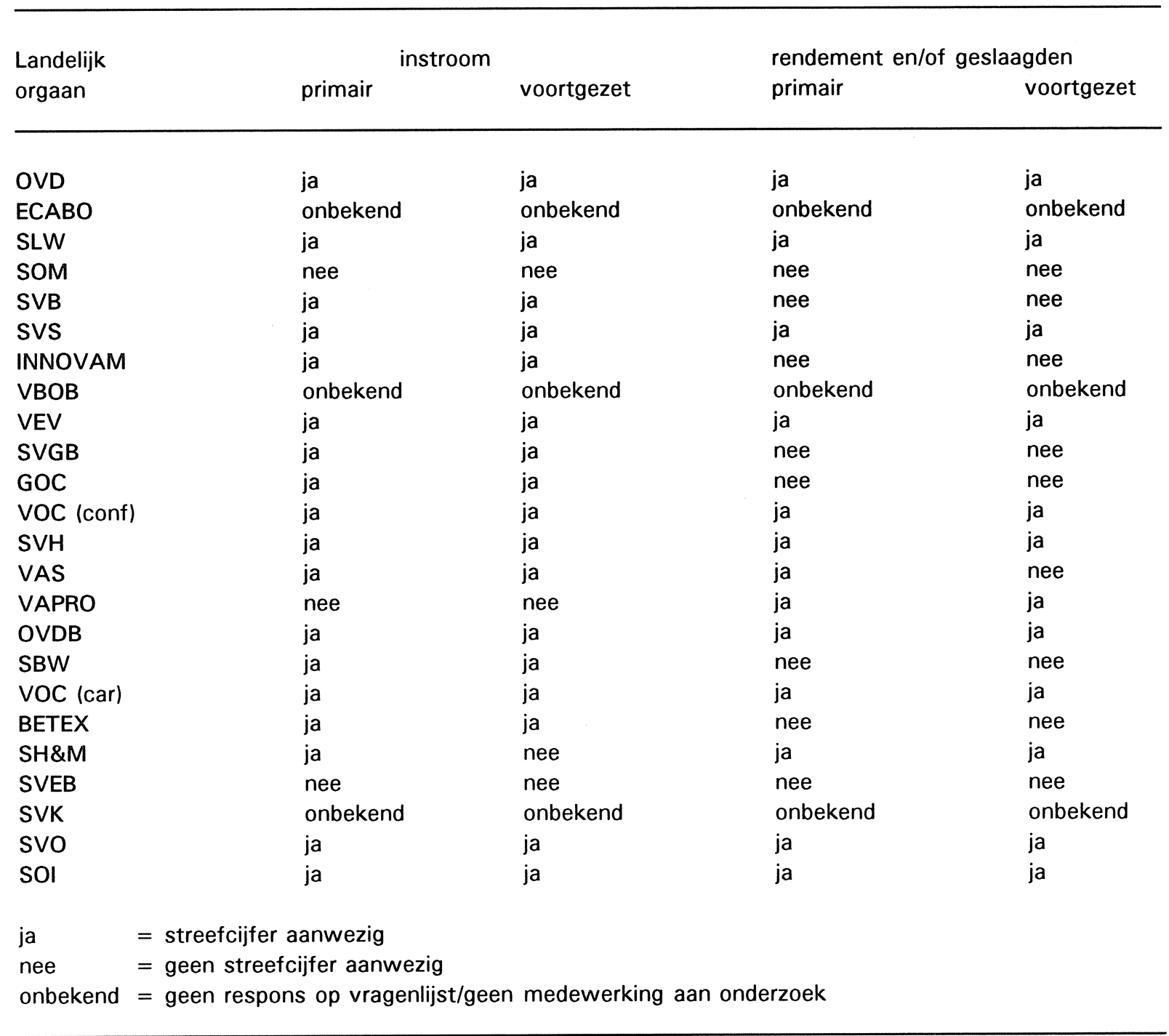

Bron: ROA

Tabel 2.6. geeft een overzicht van de enquête-resultaten. In de enquête hebben 18 van de 21 organen aangegeven dat ze over streefcijfers ten aanzien van de jaarlijkse instroom beschikken. Dit geldt zowel voor de primaire als voor de voortgezette opleidingen. Uitzondering hierop vormt de SH\&M (hout- en meubileringsbedrijf). Dit orgaan heeft alleen een streefcijfer ten aanzien van de instroom in de primaire opleidingen. Bij 13 van de 21 organen wordt een streefcijfer ten aanzien van het interne rendement gehanteerd. Van deze 13 organen heeft slechts de VAS (schoen- en lederwarenindustrie) geen streefcijfer ten aanzien van het interne rendement van de voortgezette opleidingen.

Aan de organen die een positief antwoord gaven op de vragen naar de aanwezigheid van streefcijfers ten aanzien van de instroom, is verzocht om deze cijfers voor het onderhavige onderzoek beschikbaar te stellen. Aan dit verzoek is door 10 van de 18 organen voldaan, 
waarbij twee organen de voorwaarde stelden dat de cijfers niet zouden worden gepubliceerd. Van slechts 2 van de 13 organen die zeiden over streefcijfers ten aanzien van het interne rendement te beschikken, werden die cijfers ook daadwerkelijk verkregen, waarbij één orgaan deze cijfers wel prijsgaf voor onderzoeksdoeleinden, maar niet voor publikatie.

Vanwege de beperkte mate waarin gebruik zou kunnen worden gemaakt van de bovengenoemde streefcijfers ten aanzien van de instroom en het interne rendement, is met name voor de kwantificering van de toekomstige vraag naar nieuwe leerlingen naar een alternatief gezocht. Voor de primaire opleidingen kunnen hierbij de streefcijfers die de landelijke opleidingsorganen jaarlijks indienen in het kader van de Bijdrageregeling Vakopleiding Leerlingwezen (BVL) als uitgangspunt dienen. Deze regeling is destijds door het Ministerie van Sociale Zaken en Werkgelegenheid onder de naam Bijdrageregeling Vakopleiding Jeugdigen (BVJ) in het leven geroepen om werkgevers te stimuleren leer-arbeidsplaatsen aan te bieden, zodat de instroom in het leerlingwezen op peil kan worden gehouden en zo mogelijk kan worden vergroot (zie CBA, 1992). Na de herinrichting van de arbeidsvoorzieningsorganisatie wordt de BVL uitgevoerd door het Centraal Bestuur voor de Arbeidsvoorziening. Formeel gezien worden de streefcijfers niet ingediend door de landelijke opleidingsorganen voor het leerlingwezen, maar door de paritair samengestelde opleidingsfondsen in de verschillende sectoren van het leerlingwezen. De organisaties van werkgevers en werknemers die de opleidingsfondsen beheren, zijn eveneens vertegenwoordigd in de besturen van de landelijke organen voor het leerlingwezen.

Door tussenkomst van een opleidingsfonds ontvangen werkgevers voor leerlingen die een aanvang maken met hun eerste jaar van een primaire opleiding of rechtstreeks instromen in hun eerste jaar van een voortgezette opleiding ${ }^{10}$ een financiële bijdrage in het kader van de BVL. Deze bijdrage wordt alleen verstrekt voor leerlingen die het volledige (totaal)programma van de opleiding zullen gaan volgen en die in de vijf jaar voorafgaand aan de aanvang van de leerovereenkomst in de door het desbetreffende opleidingsfonds bestreken sector niet eerder een opleiding in het kader van het leerlingwezen hebben gevolgd. Het opleidingsfonds moet bij de subsidie-aanvraag een beleidsplan overleggen waarin onder andere een onderbouwd streefcijfer is opgenomen ten aanzien van de instroom van leerlingen in het jaar waarvoor de tegemoetkoming wordt gevraagd. Dit impliceert dat de instroom én jaar vooruit wordt gepland. Tabel 2.7. geeft een overzicht van de streefcijfers die de landelijke opleidingsorganen in de afgelopen drie jaren hebben opgesteld in het kader van de BVL ${ }^{11}$.

Bij de in het kader van de BVL opgestelde streefcijfers moet worden bedacht dat deze lager uit kunnen vallen dan de totale geplande instroom, omdat niet alle nieuwe leerlingen subsidiabel zijn. Voor de primaire opleidingen kan uit de streefcijfers echter wel een trend in de totale geplande instroom worden afgeleid, omdat het overgrote deel van de nieuwe leerlingen naar alle

10. Het eerste jaar voor de leerling hoeft niet het eerste jaar van het opleidingsprogramma te zijn.

11. Deze streefcijfers zijn verkregen van de sector Scholing en Intermediaire Voorzieningen van het Centraal Bureau voor de Arbeidsvoorziening. 
waarschijnlijkheid subsidiabel is, omdat zij voor het eerst aan een opleiding in het leerlingwezen beginnen ${ }^{12}$.

Tabel 2.7. Streefcijfers in het kader van de BVL, 1990-1992

\begin{tabular}{|c|c|c|c|c|c|c|}
\hline \multirow{2}{*}{$\begin{array}{l}\text { Landelijk } \\
\text { orgaan }\end{array}$} & \multicolumn{2}{|c|}{1990} & \multicolumn{2}{|c|}{1991} & \multicolumn{2}{|c|}{1992} \\
\hline & primair & voortgezet & primair & voortgezet & primair & voortgezet \\
\hline $\mathrm{VVA}^{*}$ & 45 & 0 & 75 & 0 & 120 & 0 \\
\hline OVD & 3.168 & 1.693 & 3.400 & 1.665 & 4.300 & 1.250 \\
\hline ECABO & 2.472 & 5.113 & 2.281 & 4.690 & 2.205 & 4.965 \\
\hline SLW & 1.007 & 74 & 1.217 & 70 & 2.165 & 0 \\
\hline SOM & 4.300 & 0 & 5.339 & 281 & 4.560 & 240 \\
\hline SVB & 4.000 & 150 & 4.000 & 200 & 4.000 & 200 \\
\hline SVS & 1.680 & 40 & 1.515 & 30 & 1.480 & 50 \\
\hline INNOVAM & 3.200 & 0 & 3.250 & 0 & 2.800 & 300 \\
\hline VBOB & 412 & 18 & 425 & 25 & 425 & 25 \\
\hline VEV & 4.500 & 0 & 5.000 & 0 & 5.000 & 0 \\
\hline SVGB & 350 & 95 & 470 & 5 & 458 & 5 \\
\hline GOC & 1.435 & 24 & 2.000 & 30 & 1.500 & 30 \\
\hline VOC (conf) & 480 & 20 & 447 & 53 & 411 & 39 \\
\hline SVH & 2.795 & 150 & 2.560 & 150 & 2.965 & 50 \\
\hline VAS & 35 & 0 & 40 & 0 & 60 & 10 \\
\hline VAPRO & 1.250 & 750 & 1.450 & 1.000 & 1.450 & 1.000 \\
\hline OVDB & 3.195 & 2.270 & 2.505 & 3.195 & 2.230 & 3.640 \\
\hline SBW & 900 & 0 & 900 & 0 & 1.100 & 0 \\
\hline VOC (car) & 950 & 50 & 1.025 & 75 & 1.020 & 80 \\
\hline SLHV* & 215 & 70 & 375 & 120 & 339 & 73 \\
\hline BETEX & 250 & 35 & 275 & 50 & 303 & 47 \\
\hline SH\&M & 1.250 & 0 & 1.200 & 0 & 1.205 & 0 \\
\hline SVEB & 740 & 50 & 785 & 50 & 760 & 40 \\
\hline SVK & 2.500 & 300 & 2.250 & 250 & 2.300 & 200 \\
\hline SVO & 1.455 & 20 & 1.475 & 15 & 1.456 & 15 \\
\hline KOF* $^{*}$ & 435 & 0 & 435 & 0 & 438 & 0 \\
\hline sol & 2.210 & 370 & 2.355 & 395 & 2.395 & 383 \\
\hline IVOB* & 200 & 0 & 60 & 0 & 575 & 0 \\
\hline VOLLT" & 2.975 & 130 & 2.715 & 145 & 2.810 & 315 \\
\hline LSBC* & 270 & 75 & 373 & 141 & 315 & 155 \\
\hline LSBL $^{*}$ & 428 & 29 & 528 & 26 & 535 & 15 \\
\hline Totaal & 49.102 & 11.526 & 50.725 & 12.661 & 51.680 & 13.127 \\
\hline
\end{tabular}

Bron: CBA/ROA

12. Bij de voortgezette opleidingen is dit echter niet het geval, omdat een groot deel van de leerlingen reeds een primaire opleiding heeft gevolgd. 
In tabel 2.8. wordt voor ieder orgaan de verwachte ontwikkeling van de geplande vraag naar nieuwe leerlingen weergegeven. Deze ontwikkeling is bepaald op basis van de in tabel 2.7. vermelde streefcijfers ten aanzien van de instroom in de primaire opleidingen in de jaren 1990, 1991 en 1992. Daarbij zijn de volgende stelregels gehanteerd:

1. Indien de groei van de geplande instroom van BVL-gerechtigde leerlingen niet in zowel 1991 als 1992 tenminste $5 \%$ bedraagt, wordt verondersteld dat de totale geplande vraag naar nieuwe leerlingen constant blijft op het instroomniveau van 1992.

2. Indien de groei van de geplande instroom van BVL-gerechtigde leerlingen in zowel 1991 als 1992 tenminste $5 \%$ bedraagt en in éen van beide jaren tussen de 5 en $10 \%$ ligt, wordt verondersteld dat de totale geplande instroom tot 1997 met jaarlijks $5 \%$ groeit. Daarna blijft de totale geplande vraag constant.

3. Indien de groei van de geplande instroom van BVL-gerechtigde leerlingen zowel in 1991 als in 1992 tenminste $10 \%$ bedraagt, wordt verwacht dat de totale geplande instroom tot 1997 met jaarlijks $10 \%$ toeneemt. Daarna blijft de totale geplande vraag constant.

Tabel 2.8. Verwachte ontwikkeling van de geplande instroom in het leerlingwezen

Landelijk
orgaan

OVD
ECABO
SLW
SOM
SVB
SVS
INNOVAM
VBOB
VEV
SVGB
GOC
VOC (conf)
SVH
VAS
VAPRO
OVDB
SBW
VOC (car)
BETEX
SH\&M
SVEB
SVK
SVO
SOI

$+5 \%$ tot 1997 , daarna constant constant op het niveau van 1992 $+10 \%$ tot 1997 , daarna constant constant op het niveau van 1992 constant op het niveau van 1992 constant op het niveau van 1992 constant op het niveau van 1992 constant op het niveau van 1992 constant op het niveau van 1992 constant op het niveau van 1992 constant op het niveau van 1992 constant op het niveau van 1992 constant op het niveau van 1992 $+10 \%$ tot 1997 , daarna constant constant op het niveau van 1992 constant op het niveau van 1992 constant op het niveau van 1992 constant op het niveau van 1992 $+10 \%$ tot 1997 , daarna constant constant op het niveau van 1992 constant op het niveau van 1992 constant op het niveau van 1992 constant op het niveau van 1992 constant op het niveau van 1992

Bovenstaande stelregels leiden er toe dat voor het merendeel van de landelijke organen wordt uitgegaan van een constante instroombehoefte op het niveau van de geplande instroom van 
1992. Een uitzondering daarop vormen de OVD, de SLW, de VAS en de BETEX. Voor de OVD wordt verondersteld dat de instroombehoefte tot 1997 jaarlijks met $5 \%$ stijgt, om daarna constant te blijven op het niveau van 1997. Voor de drie andere organen wordt uitgegaan van een jaarlijkse toename van de instroombehoefte tot 1997 van $10 \%$, waarna naar verwachting een stabilisering van de instroombehoefte optreedt.

\subsection{Het instroommodel voor de primaire opleidingen}

Om een prognose op te kunnen stellen van de toekomstige instroom van leerlingen in de primaire opleidingen per landelijk orgaan, is eerst getracht een model te schatten waarin een verklaring wordt gegeven van de ontwikkeling van de totale instroom in het primaire leerlingwezen vanuit de diverse vooropleidingen. Vervolgens is op basis van een verdeelmodel deze totale instroom per vooropleiding verbijzonderd naar de 24 onderscheiden landelijke organen.

De modellering van de totale instroom per vooropleiding

In de eerste stap, waarin per vooropleiding de totale instroom in het leerlingwezen wordt gemodelleerd, is een tweetal modellen geschat:

- een 'directe doorstroom' model;

- een uitgebreid 'directe doorstroom + stuwmeer' model.

Het eerstgenoemde model veronderstelt dat alle leerlingen die instromen, dit zonder enige vertraging doen. In het tweede model wordt er rekening mee gehouden dat er naast de directe doorstroom van leerlingen uit het dagonderwijs, ook een stuwmeer bestaat van schoolverlaters die pas na enige tijd in het leerlingwezen instromen. In beide modellen is er overigens rekening mee gehouden dat er met het inzetten van de verdubbelingsoperatie in 1982 sprake zou kunnen zijn van een trendbreuk.

Het directe doorstroom model is als volgt gespecificeerd:

$$
\frac{N_{k}^{t}}{U_{k}^{t}}=a_{k}+b_{k}^{1} t^{\text {voor82 }}+b_{k}^{2} t^{n a 82}
$$

waarbij

$N_{k}^{t} \quad=$ het aantal leerlingen dat in jaar $\mathrm{t}$ instroomt in het primaire leerlingwezen met vooropleiding $\mathrm{k}$;

$U_{k}^{t} \quad=$ de uitstroom in jaar $\mathrm{t}$ uit vooropleiding $\mathrm{k}$;

$t^{\text {wor82 }}=$ trendvariabele met betrekking tot de ontwikkeling van de instroom in het primaire leerlingwezen vóór 1982 (1982=0);

$t^{n a 82}=$ trendvariabele met betrekking tot de ontwikkeling van de instroom in het primaire leerlingwezen na $1982(1982=0)$; 
$a_{k}, b_{k}^{1}$ en $b_{k}^{2}$ parameters;

$a_{k} \geq 0$.

Bij het uitgebreide model wordt verondersteld dat er naast de directe doorstroom, ook gerecruteerd kan worden uit een stuwmeer van mogelijke instromers, zoals dat zich de voorgaande vijf jaar heeft gevormd.

$S_{k}^{t}=U_{k}^{t}+U_{k}^{t-1}+U_{k}^{t-2}+U_{k}^{t-3}+U_{k}^{t-4}+U_{k}^{t-5}-N_{k}^{t-1}-N_{k}^{t-2}-N_{k}^{t-3}-N_{k}^{t-4}-N_{k}^{t-5}$

waarbij

$S_{k}^{t} \quad=$ het aantal personen met vooropleiding $\mathrm{k}$ dat in jaar $\mathrm{t}$ beschikbaar is om een opleiding in het primaire leerlingwezen te gaan volgen;

$U_{k}^{t} \quad=$ de uitstroom in jaar $\mathrm{t}$ uit vooropleiding $\mathrm{k}$;

$N_{k}^{t} \quad=$ het aantal leerlingen dat in jaar $\mathrm{t}$ instroomt in het primaire leerlingwezen met vooropleiding $\mathrm{k}$.

Het uitgebreide model wordt dan als volgt gespecificeerd:

$\frac{N_{k}^{t}}{S_{k}^{t}}=c_{k}+d_{k}^{1} t^{\text {voor82 }}+d_{k}^{2} t^{n a 82}$

waarbij

$t^{\text {voor82 }}=$ trendvariabele met betrekking tot de ontwikkeling van de instroom in het primaire leerlingwezen vóór het jaar $1982(1982=0)$;

$t^{\text {na82 }}=$ trendvariabele met betrekking tot de ontwikkeling van de instroom in het primaire leerlingwezen na het jaar $1982(1982=0)$;

$c_{k}$, $d_{k}^{1}$ en $d_{k}^{2}$ parameters;

$c_{k} \geq 0$.

Tabel 2.9. geeft een overzicht van de schattingsresultaten van zowel het directe doorstroommodel als het uitgebreide model. Beide modellen blijken, gezien de hoge gecorrigeerde $\mathrm{R}^{2}$, een goede verklaring te kunnen geven over de ontwikkeling van de totale instroom per vooropleiding. In beide modellen wordt bij alle vooropleidingen een significante trend voor de periode na 1982 waargenomen. 
Tabel 2.9. Schattingsresultaten totale instroom per vooropleiding, 1978-1990

\begin{tabular}{|c|c|c|c|c|c|c|c|c|}
\hline \multirow[b]{2}{*}{ Vooropleiding } & \multicolumn{4}{|c|}{ directe doorstroommodel } & \multicolumn{2}{|c|}{ uitgebreide model } & \multirow[b]{2}{*}{ trend } & \multirow[b]{2}{*}{$\bar{R}^{2}$} \\
\hline & constante & $\begin{array}{c}\text { trend } \\
\text { voor } \\
1982\end{array}$ & $\begin{array}{r}\text { trend } \\
\text { na } \\
1982\end{array}$ & $\bar{R}^{2}$ & $\begin{array}{r}\text { constante } \\
\text { voor } \\
1982\end{array}$ & $\begin{array}{r}\text { trend } \\
\text { na } \\
1982\end{array}$ & & \\
\hline LTOMD & $\begin{array}{r}0,49106 \\
(18,03)\end{array}$ & $\begin{array}{r}-0,06178 \\
(5,08)\end{array}$ & $\begin{array}{r}0,09298 \\
(13,85)\end{array}$ & 0,99 & $\begin{array}{r}0,13416 \\
(4,25)\end{array}$ & $\begin{array}{r}-0,05059 \\
(3,32)\end{array}$ & $\begin{array}{r}0,05156 \\
(5,64)\end{array}$ & 0,96 \\
\hline LHNOMD & $\begin{array}{r}0,23345 \\
(17,27)\end{array}$ & - & $\begin{array}{r}0,05107 \\
(11,46)\end{array}$ & 0,99 & $\begin{array}{r}0,04565 \\
(14,73)\end{array}$ & - & $\begin{array}{r}0,01218 \\
(10,98)\end{array}$ & 0,98 \\
\hline LMOMD & $\begin{array}{r}0,06472 \\
(6,47)\end{array}$ & - & $\begin{array}{r}0,01686 \\
(5,86)\end{array}$ & 0,94 & $\begin{array}{r}0,01056 \\
(8,85)\end{array}$ & $\begin{array}{l}- \\
-\end{array}$ & $\begin{array}{r}0,00315 \\
(8,75)\end{array}$ & 0,97 \\
\hline LEAOMD & $\begin{array}{r}0,07843 \\
(4,20)\end{array}$ & - & $\begin{array}{r}0,04201 \\
(6,59)\end{array}$ & 0,91 & $\begin{array}{r}0,01358 \\
(4,12)\end{array}$ & - & $\begin{array}{r}0,00688 \\
(6,59)\end{array}$ & 0,92 \\
\hline MAVOMD & $\begin{array}{r}0,17605 \\
(6,36)\end{array}$ & - & $\begin{array}{r}0,09871 \\
(8,17)\end{array}$ & 0,93 & $\begin{array}{r}0,02447 \\
(5,11)\end{array}$ & - & $\begin{array}{r}0,02586 \\
(8,57)\end{array}$ & 0,93 \\
\hline LTOZD & $\begin{array}{r}0,13694 \\
(5,69)\end{array}$ & $\begin{array}{r}-0,03721 \\
(3,87)\end{array}$ & $\begin{array}{r}0,02332 \\
(3,55)\end{array}$ & 0,97 & $\begin{array}{r}0,02113 \\
(6,65)\end{array}$ & $\begin{array}{r}-0,01403 \\
(9,08)\end{array}$ & $\begin{array}{r}0,00429 \\
(5,09)\end{array}$ & 0,98 \\
\hline OVTRADZD & $\begin{array}{r}0,08026 \\
(6,70)\end{array}$ & $\begin{array}{r}-0,01694 \\
(3,49)\end{array}$ & $\begin{array}{r}0,01678 \\
(5,63)\end{array}$ & 0,97 & $\begin{array}{r}0,01031 \\
(4,908)\end{array}$ & $\begin{array}{r}-0,00456 \\
(4,96)\end{array}$ & $\begin{array}{r}0,00359 \\
(5,85)\end{array}$ & 0,97 \\
\hline
\end{tabular}

- = insignificant

Bron: ROA

Zoals we in figuur 2.1. zagen, was in de jaren 1988-1990 de instroom van leerlingen met een LTO-diploma groter dan het aantal gediplomeerde schoolverlaters van het LTO in hetzelfde jaar. Hetzelfde geldt, zij het in iets mindere mate, voor het MAVO in 1989 (zie figuur 2.5.). Dit wijst er overduidelijk op dat met name bij een krappe arbeidsmarkt in grote mate uit het bestaande 'stuwmeer' van potentiële leerlingen wordt gerecruteerd, al is het evident dat een dergelijke uitputting van het stuwmeer niet structureel kan blijven voortbestaan.

Op basis van deze overwegingen, is het het meest realistisch om de prognose van de toekomstige instroom in de primaire opleidingen te baseren op het uitgebreide model. Temeer daar het model bedoeld is voor het opstellen van middellange- en lange-termijn prognoses. Daarbij is bij de LTO-gediplomeerden een tweetal correcties toegepast.

1. Daar als gevolg van de opgenomen trendterm het verwachte instroompercentage van LTOgediplomeerden in 1995 reeds op $80 \%$ komt te liggen, hetgeen in vergelijking tot de huidige $60 \%$ zeer hoog is, wordt verondersteld dat dit percentage na 1995 niet verder stijgt.

2. Om niet realistische extreme fluctuaties in het instroompercentage van de gediplomeerde LTO-ers tegen te gaan, wordt bovendien verondersteld dat er sprake is van een geleidelijke aanpassing aan de modelvoorspelling:

$\tilde{N}_{\text {LTOMD }}^{t}=0,5 \tilde{N}_{\text {LTOMD }}^{t-1}+0,5 \hat{N}_{\text {LTOMD }}^{t}$ 
waarbij:

$\tilde{N}_{L T O M D}^{t}=$ het verwachte aantal leerlingen dat in jaar $\mathrm{t}$ zal instromen in het primaire leerlingwezen met een LTO-diploma;

$\hat{N}_{L T O M D}^{t}=$ de modelvoorspelling van het aantal leerlingen dat in jaar $\mathrm{t}$ zal instromen in het primaire leerlingwezen met een LTO-diploma.

Tenslotte moet nog worden opgemerkt dat er voor de 'overige (voor)opleidingen' geen instroommodel is geschat. In het basisscenario wordt verondersteld dat de instroom uit deze vooropleidingen constant blijft op het niveau van 1991. Enerzijds sluit dit aan bij de stabilisering van de instroom uit deze vooropleidingen in de jaren 1989-1991. Anderzijds wordt het op deze wijze mogelijk gemaakt bij de alternatieve scenario's aan te geven welke additionele instroom uit deze niet-traditionele vooropleidingen van het leerlingwezen is vereist om te kunnen voorzien in de vraag naar leerlingen.

Het verdeelmodel van de instroom naar landelijk orgaan

Nadat de modellering van de instroom per vooropleiding heeft plaatsgevonden, wordt deze instroom verdeeld over de verschillende landelijke organen. In dit verdeelmodel wordt de instroom per vooropleiding omgezet in de instroom vanuit de desbetreffende vooropleiding naar de verschillende landelijke organen. Door uit te gaan van een verdeelmodel is er de garantie dat bij iedere vooropleiding de totale omvang van de voorspelde instroom consistent is met de in de eerste stap voorspelde grootte van de instroom. In formulevorm:

$\sum_{k} N_{k}^{t}=\sum_{k} \sum_{l} N_{k l}^{t}=\sum_{l} N_{l}^{t}$

waarbij:

$N_{k}^{t}=\quad$ het aantal leerlingen dat in jaar $t$ instroomt in het primaire leerlingwezen, met vooropleiding $k$;

$N_{k l}^{t}=\quad$ het aantal leerlingen dat in jaar $t$ instroomt in het primaire leerlingwezen bij orgaan $l$ met vooropleiding $k$;

$N_{l}^{t}=\quad$ het aantal leerlingen dat in jaar $t$ instroomt in het primaire leerlingwezen bij orgaan $l$.

Noem $f_{k l}^{t}=N_{k l}^{t} / N_{k}^{t}$ de fractie van de instroom met vooropleiding $k$ die instroomt bij orgaan $l$. Gesommeerd over de organen tellen deze fracties per vooropleiding op tot 1 :

$\sum_{l} f_{k l}=1$

In het verdeelmodel wordt de onwikkeling van deze fracties geschat met behulp van een 
Random Coefficients Model (R-C model), zoals dat recentelijk door het ROA is ontwikkeld ${ }^{13}$. In dit R-C model wordt, in tegenstelling tot andere schattingsmethoden, rekening gehouden met de betrouwbaarheid van de gevonden verbanden tussen de endogene en de verklarende variabelen.

De effectiviteit van het R-C model werd aangetoond door de modeluitkomsten te vergelijken met de uitkomsten van standaardmethoden (logit-model, gewone kleinste kwadratenmethode). De prognoses op basis van deze standaardmethoden leidden voortdurend tot een explosie van één van de fracties (tot deze de waarde 1 bereikt), waardoor de fracties van de andere landelijke organen tot nul reduceerden.

In het verdeelmodel wordt de groei van de fractie gemodelleerd als een constante factor en een factor die samenhangt met de groei van de instroom met de desbetreffende vooropleiding:

$\dot{f}_{k l}^{t}=a_{k l} \uparrow^{t}+b_{k l} \dot{N}_{k}^{t}$

waarbij:

$\dot{f}_{k l}^{t}=\left(f_{k l}^{t}-f_{k l}^{t-1}\right) / f_{k l}^{t-1} \quad \equiv$ groei van de fractie van orgaan $l$ in vooropleiding $k$;

$\dot{N}_{k}^{t}=\left(N_{k}^{t}-N_{k}^{t-1}\right) / N_{k}^{t-1} \equiv$ groei van de instroom met vooropleiding $k$;

$a_{k l}, b_{k l}$ parameters.

De parameter voor de constante groei $\left(a_{k l}\right)$ geeft aan in welke mate er sprake is van een constante groei van de fractie. Deze parameter geeft aan of het aandeel van een orgaan in een bepaalde vooropleiding toe- of afneemt, onafhankelijk van de volume-ontwikkeling van de instroom vanuit deze vooropleiding. De parameter voor de groei van de instroom van de desbetreffende vooropleiding $\left(b_{k t}\right)$ geeft daarentegen aan in welke mate de groei van de fractie afhankelijk is van de volume-ontwikkelingen van de instroom vanuit de vooropleiding. Het verdeelmodel is geschat over de periode 1979-1982 en over de periode 1982-1991. In de uiteindelijke prognoses wordt uitgegaan van de schattingen die volgen uit de laatste periode (vanaf de start van de verdubbelingsoperatie). Vanwege de omvang van het datamateriaal zal hier niet nader worden ingegaan op de schattingsresultaten van dit verdeelmodel.

Tenslotte wordt de totale instroom per landelijk orgaan verkregen door de geschatte fracties uit het verdeelmodel te vermenigvuldigen met de geschatte instroom per vooropleiding en dit per orgaan te aggregeren over de verschillende vooropleidingen:

$\hat{N}_{l}^{t}=\sum_{k} \hat{f}_{k l} \cdot \hat{N}_{k}^{t}$

13. Zie voor een technische uitleg Borghans en Heijke (1993). 


\subsection{Verwachte instroom primaire opleidingen 1993-2001}

Op basis van het in de vorige paragraaf beschreven instroommodel kunnen prognoses worden opgesteld van de te verwachten instroom van leerlingen in de primaire opleidingen van het leerlingwezen, verbijzonderd naar de 24 onderscheiden organen. Deze prognoses kunnen worden beschouwd als het 'basisscenario' van de te verwachten instroom in de periode 19932001.

\section{Verwachte totale instroom per vooropleiding}

In de figuren 2.10.-2.16. wordt een overzicht gegeven van de verwachte ontwikkeling van de totale instroom van leerlingen in de primaire opleiding, verbijzonderd naar de zeven 'traditionele' vooropleidingen. In de figuren is deze instroom telkens afgezet tegen de prognose van de voor het desbetreffende jaar verwachte uitstroom van leerlingen vanuit het desbetreffende opleidingstype. Deze uitstroomprognoses zijn ontleend aan de Referentieraming 1992 van het Ministerie van Onderwijs en Wetenschappen.

Figuur 2.10. Prognose gediplomeerde uitstroom LTO versus prognose instroom gediplomeerden LTO in het primair leerlingwezen, 1991-2001*

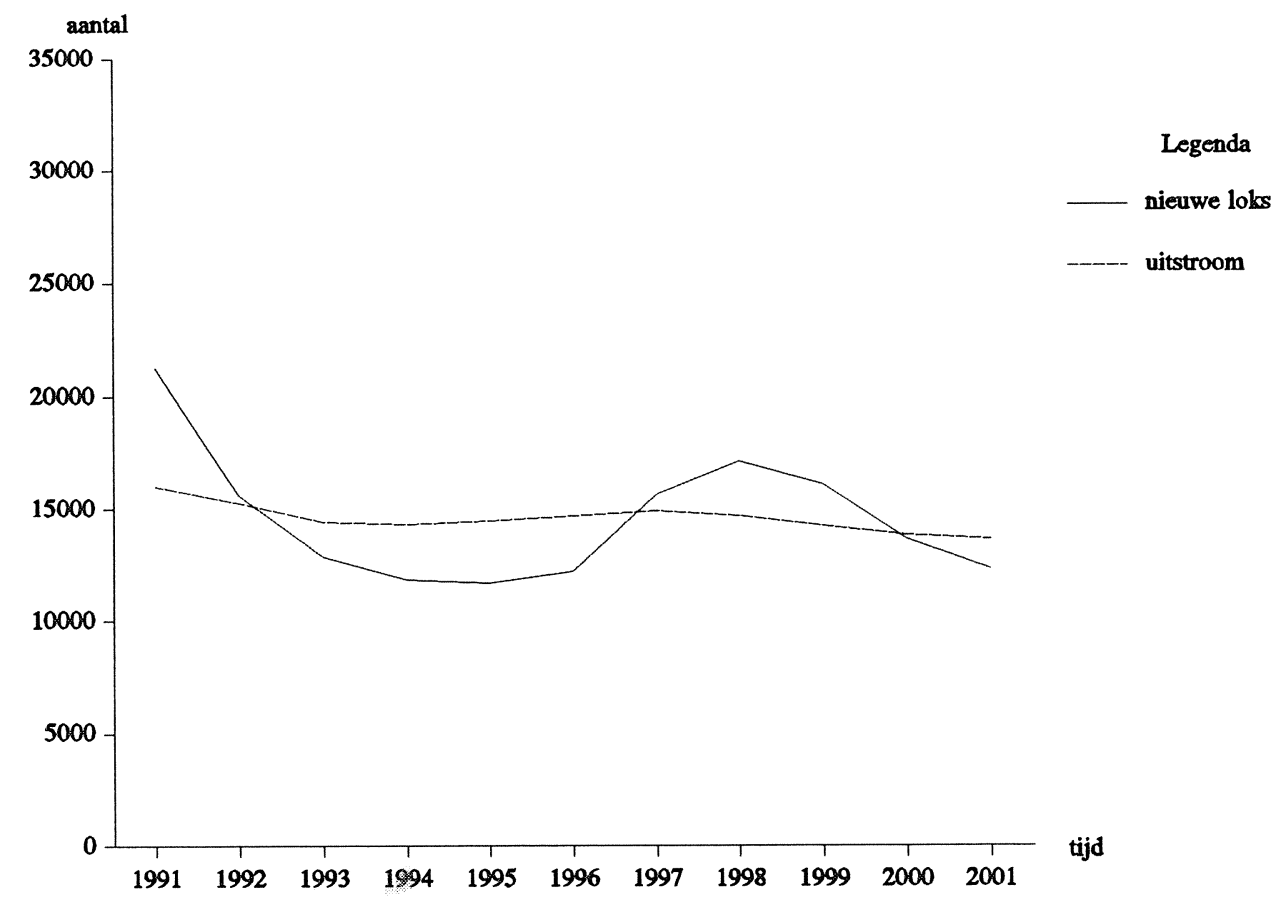

* Cijfer 1991 is geen prognose, maar realisatie Bron: O\&W/ROA 
Figuur 2.11. Prognose gediplomeerde uitstroom LHNO versus prognose instroom gediplomeerden LHNO in het primair leerlingwezen, 1991-2001*

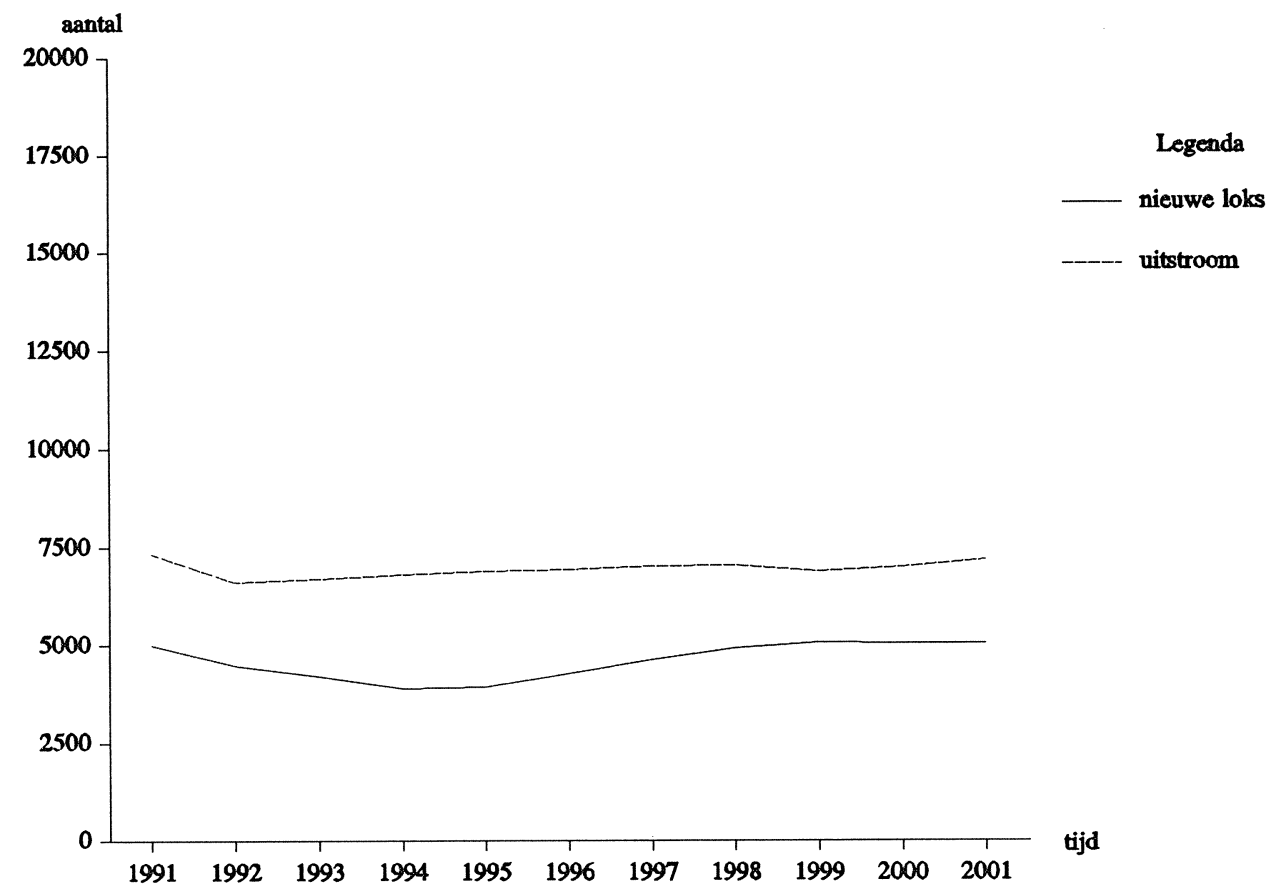

* Cijfer 1991 is geen prognose, maar realisatie Bron: O\&W/ROA

Figuur 2.12. Prognose gediplomeerde uitstroom LMO versus prognose instroom gediplomeerden LMO in het primair leerlingwezen, 1991-2001*

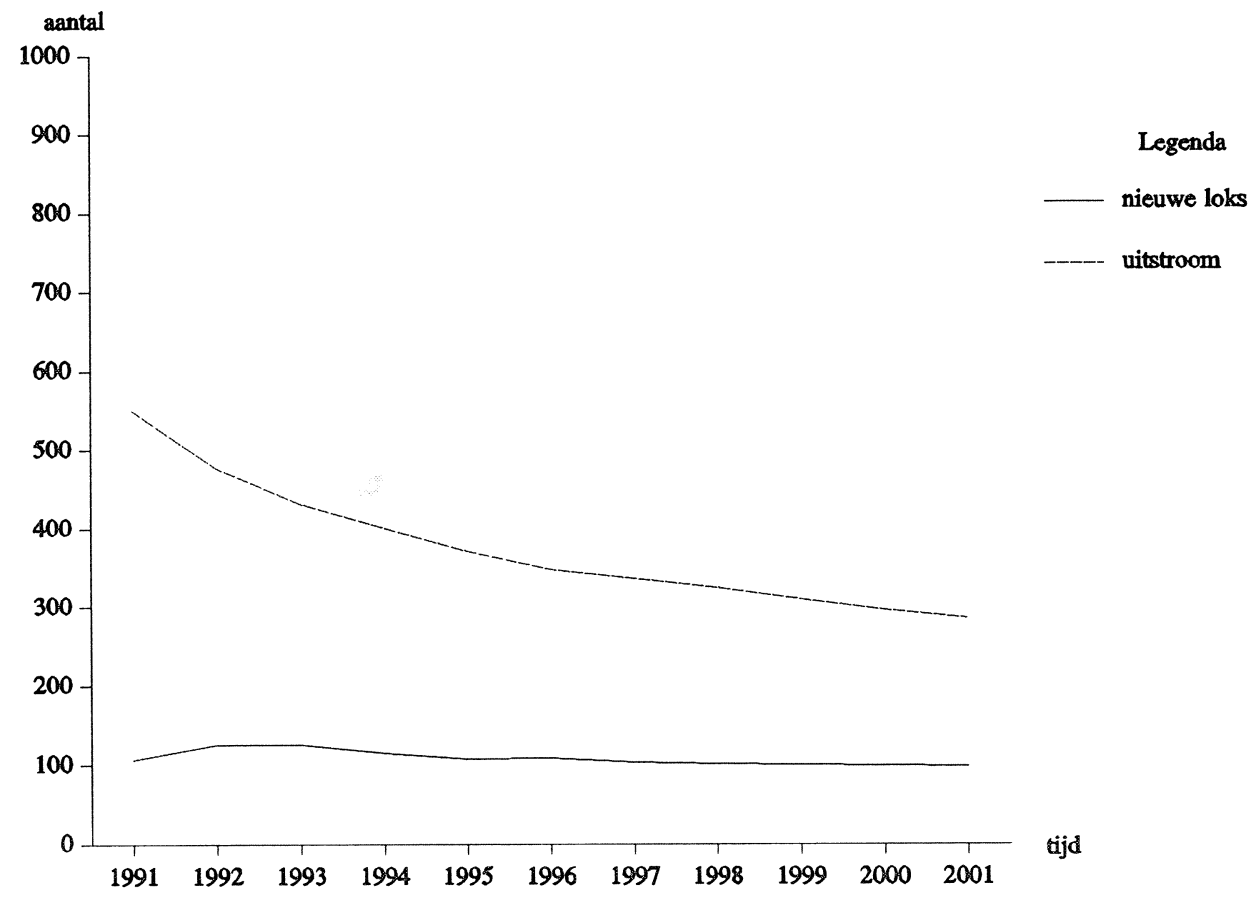

* Cijfer 1991 is geen prognose, maar realisatie

Bron: O\&W/ROA 
Figuur 2.13. Prognose gediplomeerde uitstroom LEAO versus prognose instroom gediplomeerden LEAO in het primair leerlingwezen, 1991-2001*

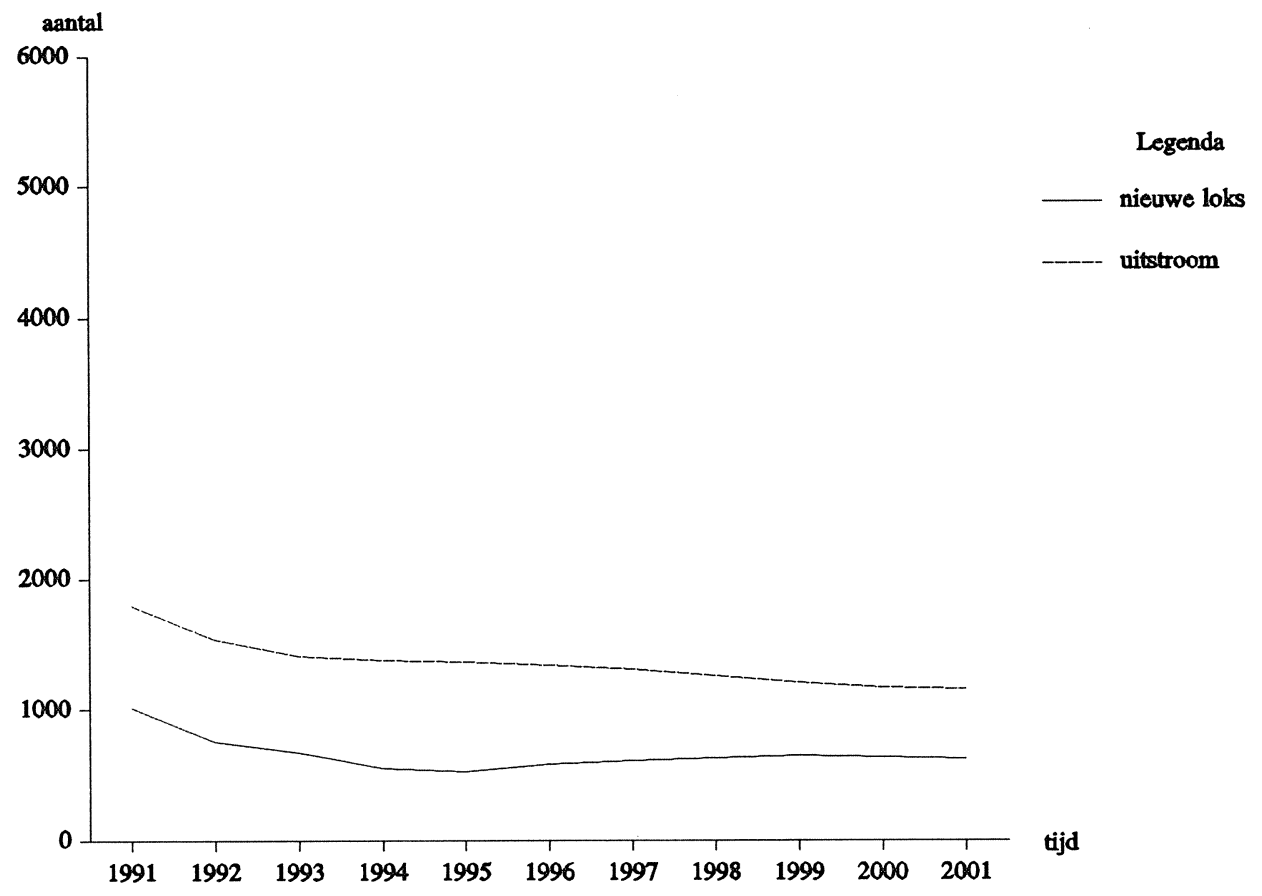

* Cijfer 1991 is geen prognose, maar realisatie Bron: O\&W/ROA

Figuur 2.14. Prognose gediplomeerde uitstroom MAVO versus prognose instroom gediplomeerden MAVO in het primair leerlingwezen, 1991-2001*

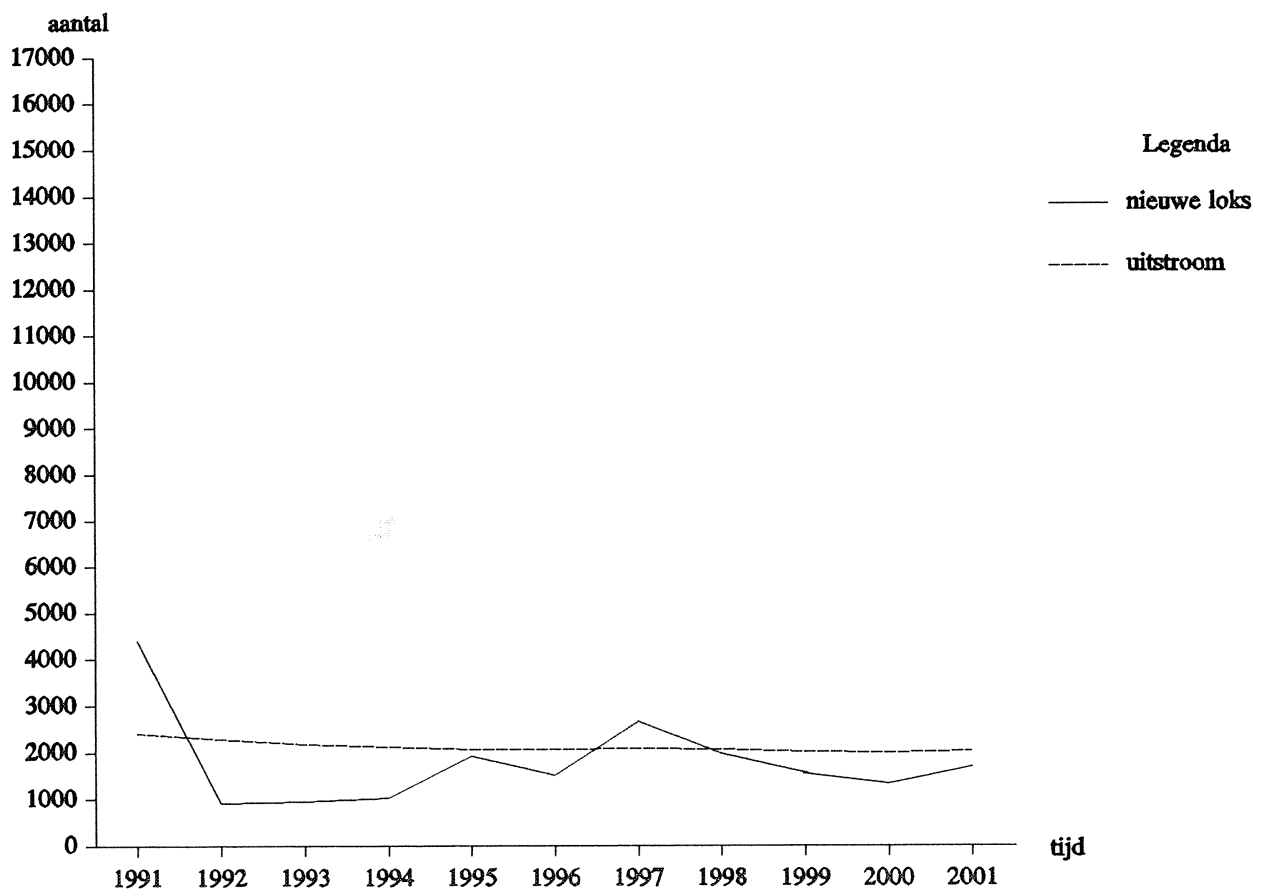

Cijfer 1991 is geen prognose, maar realisatie 
Figuur 2.15. Prognose ongediplomeerde uitstroom LTO versus prognose instroom ongediplomeerden LTO in het primair leerlingwezen, 1991-2001*

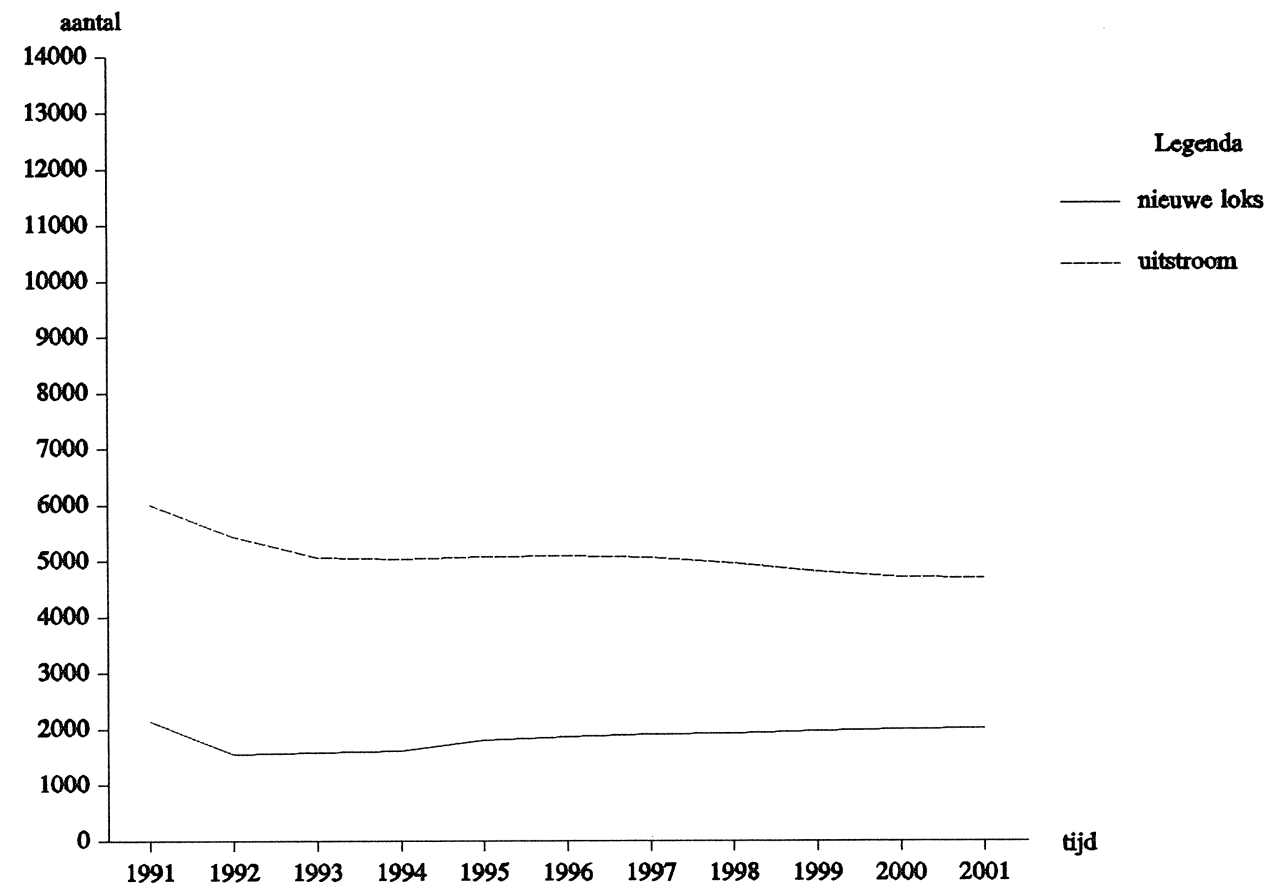

* Cijfer 1991 is geen prognose, maar realisatie Bron: O\&W/ROA

Figuur 2.16. Prognose ongediplomeerde uitstroom overige traditionele vooropleidingen versus prognose instroom ongediplomeerden overige traditionele vooropleidingen in het primair leerlingwezen, 1991-2001*

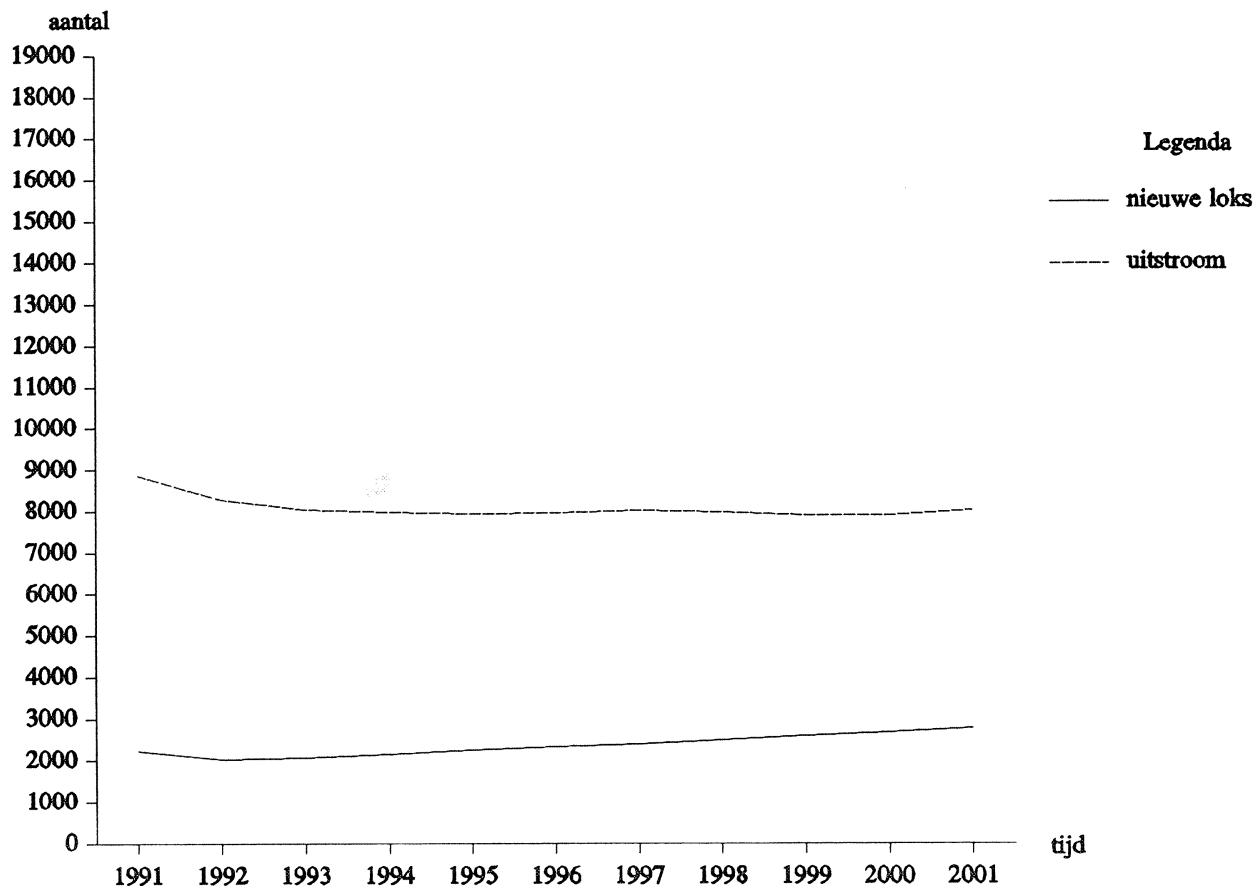

* Cijfer 1991 is geen prognose, maar realisatie Bron: O\&W/ROA 
Figuur 2.10. laat zien dat in navolging van de verwachte jaarlijkse uitstroom van LTOgediplomeerden uit het initiële dagonderwijs, ook de verwachte instroom van LTOgediplomeerden in de primaire opleidingen van het leerlingwezen in de eerste helft van de jaren negentig sterk terug loopt ${ }^{14}$. Het spreekt voor zich dat dit grote gevolgen heeft voor de instroom in de diverse primaire opleidingen, die in belangrijke mate afhankelijk zijn van LTOgediplomeerden. Bovendien blijkt uit de figuur dat het recruteren van leerlingen uit het stuwmeer van gediplomeerden, als gevolg van de 'uitputting' van dit stuwmeer die de laatste jaren plaats vond (zie figuur 2.1.), vanaf 1993 niet langer mogelijk is. Integendeel, als gevolg van de uitputting van dit stuwmeer zal de totale instroom van LTO-gediplomeerden in het midden van de jaren negentig zelfs weer achter blijven bij de jaarlijkse uitstroom, om er vanaf 1997 weer voor enige jaren boven uit te stijgen.

Voor de overige vooropleidingen zijn de prognoseresultaten minder spectaculair. Bij de LHNOgediplomeerden treedt er naar verwachting een stabilisering op van de uitstroom uit het dagonderwijs. De daling van de instroom in de primaire opleidingen, die in het begin van de jaren negentig is ingezet zal zich nog voortzetten tot 1995, waarna weer enig herstel wordt verwacht (zie figuur 2.11.). Een soortgelijk patroon doet zich voor bij de instroom van LEAOgediplomeerden (zie figuur 2.13.). Daarentegen valt de instroom van MAVO-gediplomeerden in het begin van de jaren negentig weer sterk terug, in navolging van de uitstroom van leerlingen met een MAVO-diploma uit het voltijdonderwijs (zie figuur 2.14.). Ook hier wordt, als gevolg van het grote beroep dat aan het eind van de jaren tachtig en het begin van de jaren negentig werd gedaan op het stuwmeer van gediplomeerden, verwacht dat de totale instroom in de primaire opleidingen tot 1997 achter blijft bij de jaarlijkse uitstroom van gediplomeerden.

Voor de ongediplomeerde instroom met een traditionele vooropleiding van het leerlingwezen wordt een licht stijgende trend verwacht, hetgeen betekent dat een groter deel van de ongeschoolde uitstroom zal worden gerecruteerd voor een primaire opleiding in het leerlingwezen (zie figuur 2.15. en 2.16.).

\section{Basisscenario instroom per landelijk orgaan}

Tabel 2.10. geeft een overzicht van de volgens het basisscenario verwachte ontwikkeling van de instroom per landelijk orgaan van de jaren 1997 en 2001. Een volledig overzicht over alle prognosejaren 1993-2001 is te vinden in bijlage $D$.

Ter vergelijking is in de tabel ook de instroom opgenomen in het laatste jaar (1991) waarover feitelijke gegevens beschikbaar zijn. Over het geheel genomen is de verwachting dat de instroom van leerlingen in 1997 sterk is afgenomen ten opzichte van de instroom in 1991. Het gaat daarbij om een daling van de instroom van ruim 45.000 leerlingen in 1991 naar nog geen

14. Daar in de door ons opgestelde prognoses de verwachtingen op middellange- en lange termijn centraal staan, moet ten aanzien van de exacte timing van deze terugval het voorbehoud worden gemaakt dat de daling van de instroom zich niet altijd precies in het in de figuur aangegeven jaar hoeft voor te doen. 
37.000 leerlingen in 1997, een daling van circa $18 \%$. Het meest opvallend is de daling van de instroom bij de SBW (-35\%), de SVEB $(-34 \%)$, de ECABO $(-33 \%)$ en de VEV $(-32 \%)$. Daarentegen wordt in de periode 1991-1997 voor slechts drie landelijke organen een toename van de instroom verwacht: de SVGB $(+35 \%)$, de BETEX $(+7 \%)$ en de OVD $(+2 \%)$. Voor de VOC (confectietechniek) is de instroom naar verwachting stabiel.

Tabel 2.10. Verwachte instroom in het primaire leerlingwezen per landelijk orgaan volgens het basisscenario, 1997 en 2001 (absolute aantallen)

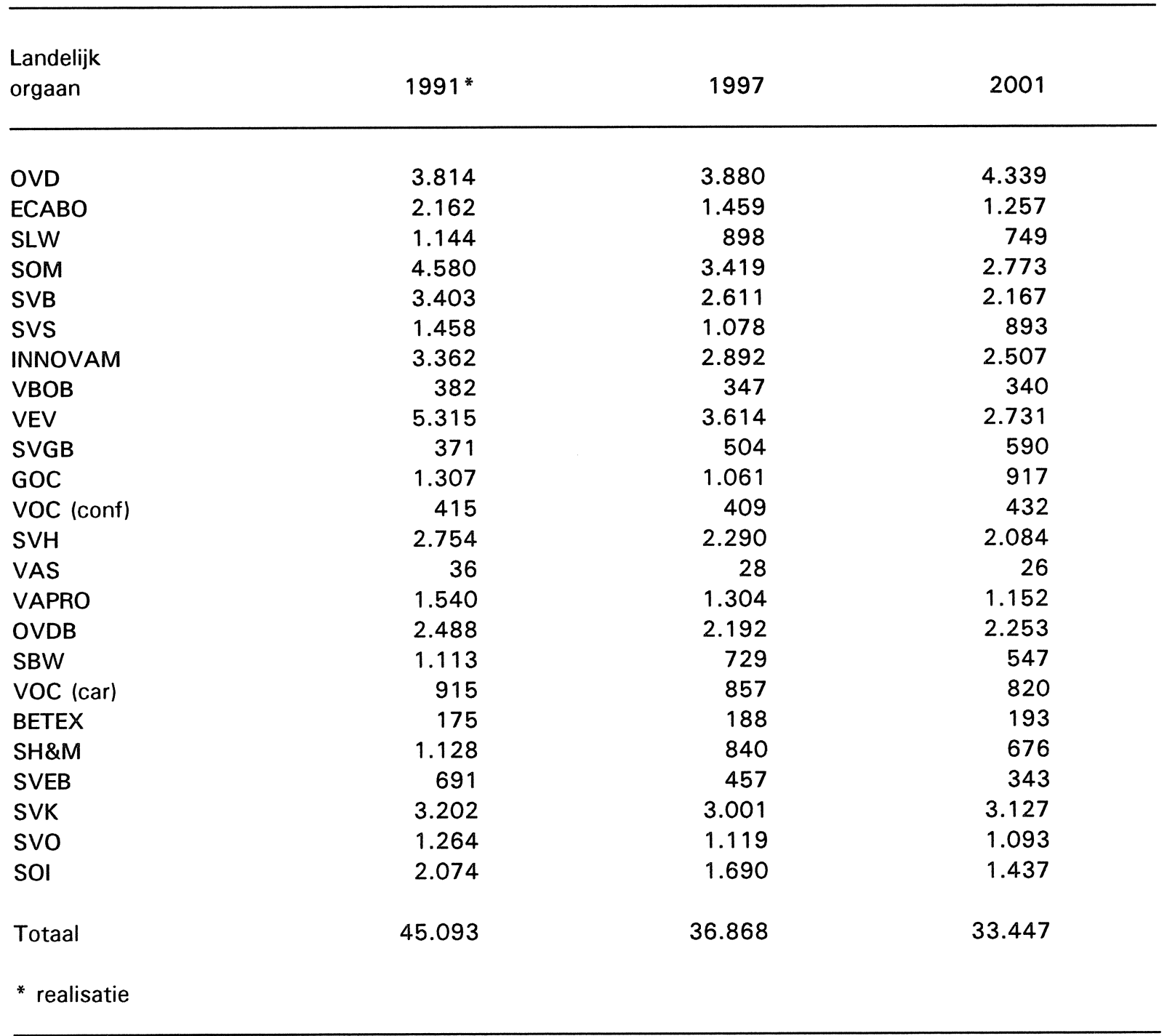

Bron: ROA

Voor de periode 1997-2001 wordt een verdere daling van de leerlingeninstroom verwacht van bijna $10 \%$. Opnieuw is de daling naar verwachting het grootst bij de SBW $(-25 \%)$, de SVEB $(-25 \%)$ en de VEV $(-24 \%)$. Daarentegen wordt er in deze periode bij 6 landelijke organen een toename van de instroom van leerlingen verwacht. Naast de organen die ook in de periode 1991-1997 hun instroom zien toenemen, de SVGB $(+17 \%)$, de OVD $(+12 \%)$ en de BETEX $(+3 \%)$, wordt nu ook een geringe toename van de leerlingeninstroom verwacht bij de VOC 
(confectie techniek, $+6 \%$ ), de SVK $(+4 \%)$ en de OVDB $(+3 \%)$.

\subsection{Verwachte aanbodoverschotten en -tekorten 1993-2001}

Om na te gaan in hoeverre de verschillende landelijke organen in hun toekomstige behoefte aan instromers voor de primaire opleidingen kunnen voorzien, is een confrontatie gemaakt van de prognoses van de verwachte leerlingeninstroom volgens het basisscenario met de in paragraaf 2.3. afgeleide beleidsdoelstellingen van de landelijke organen ${ }^{15}$. Tabel 2.11 geeft hiervan een overzicht voor de prognosejaren 1997 en 2001 . Een volledig overzicht voor alle prognosejaren 1993-2001 is te vinden in bijlage $\mathrm{E}$.

Tabel 2.11. Verwachte aanbodoverschotten en -tekorten aan nieuwe leerlingen in het primaire leerlingwezen volgens het basisscenario, 1997 en 2001 (absolute aantallen en als percentage van de geplande instroom)

\begin{tabular}{|c|c|c|c|c|}
\hline \multirow{2}{*}{$\begin{array}{l}\text { Landelijk } \\
\text { orgaan }\end{array}$} & \multicolumn{2}{|c|}{1997} & \multicolumn{2}{|c|}{2001} \\
\hline & aantal & $\%$ & aantal & $\%$ \\
\hline OVD & -1.608 & -29 & -1.149 & -21 \\
\hline ECABO & -746 & -34 & -948 & -43 \\
\hline SLW & -2.589 & -74 & -2.738 & -79 \\
\hline SOM & -1.141 & -25 & -1.787 & -39 \\
\hline SVB & -1.389 & -35 & -1.833 & -46 \\
\hline SVS & -402 & -27 & -587 & -40 \\
\hline INNOVAM & 92 & 3 & -293 & -10 \\
\hline VBOB & -78 & -18 & -85 & -20 \\
\hline VEV & -1.386 & -28 & -2.269 & -45 \\
\hline SVGB & 46 & 10 & 132 & 29 \\
\hline GOC & -439 & -29 & -583 & -39 \\
\hline VOC (conf) & -2 & -1 & 21 & 5 \\
\hline SVH & -675 & -23 & -881 & -30 \\
\hline VAS & -69 & -71 & -71 & -73 \\
\hline VAPRO & -146 & -10 & -298 & -21 \\
\hline OVDB & -38 & -2 & 23 & 1 \\
\hline SBW & -371 & -34 & -553 & -50 \\
\hline VOC (car) & -163 & -16 & -200 & -20 \\
\hline BETEX & -300 & -61 & -295 & -60 \\
\hline SH\&M & -365 & -30 & -529 & -44 \\
\hline SVEB & -303 & -40 & -417 & -55 \\
\hline SVK & 701 & 30 & 827 & 36 \\
\hline svo & -337 & -23 & -363 & -25 \\
\hline SOI & -705 & -29 & -958 & -40 \\
\hline Totaal & -12.411 & -25 & -15.833 & -32 \\
\hline
\end{tabular}

Bron: ROA

15. Zoals reeds werd aangegeven worden de instroomprognoses daarbij geconfronteerd met de BVLstreefcijfers, die doorgaans ietwat lager liggen dan de totale geplande uitstroom. 
Uit tabel 2.11 blijkt dat voor 1997 in totaal een aanbodtekort wordt verwacht van ruim 12.000 leerlingen. In procenten van de geplande leerlingeninstroom gaat het hier om een tekort van $25 \%$. De grootste tekorten worden verwacht bij de landelijke organen, waarvoor de geplande toename van de instroom (zie tabel 2.8.) het grootst is: de SLW (tekort 74\%), de VAS (tekort $71 \%$ ) en de BETEX (tekort $61 \%$ ). Andere organen die naar verwachting met een verhoudingsgewijs groot leerlingentekort worden geconfronteerd zijn de SVEB (tekort $40 \%$ ), de SVB (tekort $35 \%$ ), de ECABO (tekort $34 \%$ ) en de SBW (tekort $34 \%$ ).

Slechts een beperkt aantal organen zal in 1997 naar verwachting (nog) niet geconfronteerd worden met een tekort schietende leerlingeninstroom: de SVK, de SVGB en de INNOVAM. Ook bij de VOC (confectietechniek) en de OVDB zal niet of nauwelijks sprake zijn van een leerlingentekort. Bij de SVK wordt zelfs een relatief omvangrijk overschot verwacht.

Op de lange termijn wordt verwacht dat het totale leerlingentekort zal uitgroeien tot bijna 16.000 in het jaar 2001. In procenten van de geplande instroom is dit een tekort van $32 \%$. In het algemeen zullen in 2001 dezelfde organen als in 1997 met verhoudingsgewijs grote tekorten worden geconfronteerd. Daarbij wordt vooral een sterke toename van het tekort verwacht bij de VEV (van 28\% naar $45 \%$ ), de SBW (van $34 \%$ naar $50 \%$ ) en de SVEB (van $40 \%$ naar 55\%). Bij de INNOVAM slaat het overschot in 1997 om in een tekort in 2001. 



\section{DE UITSTROOM UIT DE PRIMAIRE OPLEIDINGEN}

\subsection{Inleiding}

Om prognoses te kunnen opstellen van de te verwachten uitstroom van geschoolde vakmensen uit de primaire opleidingen van het leerlingwezen, is het noodzakelijk om de in het vorige hoofdstuk gepresenteerde instroomprognoses te combineren met prognoses van het (longitudinale) interne rendement van de primaire opleidingen. In dit hoofdstuk zal een model worden geschat waarin per landelijk orgaan de jaarlijkse uitstroom van leerlingen uit de primaire opleidingen van het leerlingwezen wordt gerelateerd aan de instroom van leerlingen in de voorgaande jaren. Op basis van de schattingsresultaten van dit uitstroommodel zullen voor de verschillende landelijke organen prognoses worden opgesteld van de te verwachten uitstroom in de periode 1993-2001. De schattingsresultaten van het uitstroommodel geven tevens een overzicht van het interne rendement van de primaire opleidingen in de periode 1980-1991, verbijzonderd naar landelijk orgaan. Om na te gaan of er in de loop van de jaren tachtig, mogelijk mede als gevolg van de ingezette beleidswijzigingen in het leerlingwezen, significante veranderingen in het rendement zijn opgetreden, is het uitstroommodel ook geschat voor twee deelperiodes: 1980-1985 en 1986-1991.

De opzet van dit hoofdstuk is als volgt. Eerst zal in paragraaf 3.2. een korte beschrijving worden gegeven van de ontwikkeling van de gediplomeerde uitstroom van de primaire opleidingen in de periode 1976-1991. Daarna wordt in paragraaf 3.3. nader ingegaan op de specificatie van het uitstroommodel en de schattingsresultaten van het model, verbijzonderd naar de verschillende landelijke organen. Deze schattingsresultaten geven een overzicht van het interne rendement van de primaire opleidingen in de periode 1980-1991, met een verbijzondering naar de beide bovengenoemde deelperiodes. Tenslotte wordt in paragraaf 3.4. een overzicht gegeven van de uitstroomprognoses per landelijk orgaan.

\subsection{De ontwikkeling van de uitstroom in het verleden}

Figuur 3.1. geeft een overzicht van de ontwikkeling van de totale gediplomeerde uitstroom van de primaire opleidingen in het leerlingwezen in de periode 1976-1991. Uit de figuur blijkt duidelijk de conjunctuurgevoeligheid van het leerlingwezen, die met een vertraging van circa 2 jaar tot uiting komt in de uitstroomcijfers. Daarnaast valt uit de figuur goed de doorwerking van de in 1982 ingezette verdubbelingsoperatie af te lezen, waarbij overigens aan het begin van de jaren negentig de groei van de uitstroom blijkt te stagneren. 
Figuur 3.1. Gediplomeerde uitstroom van de primaire opleidingen in het leerlingwezen, 1976 - 1991

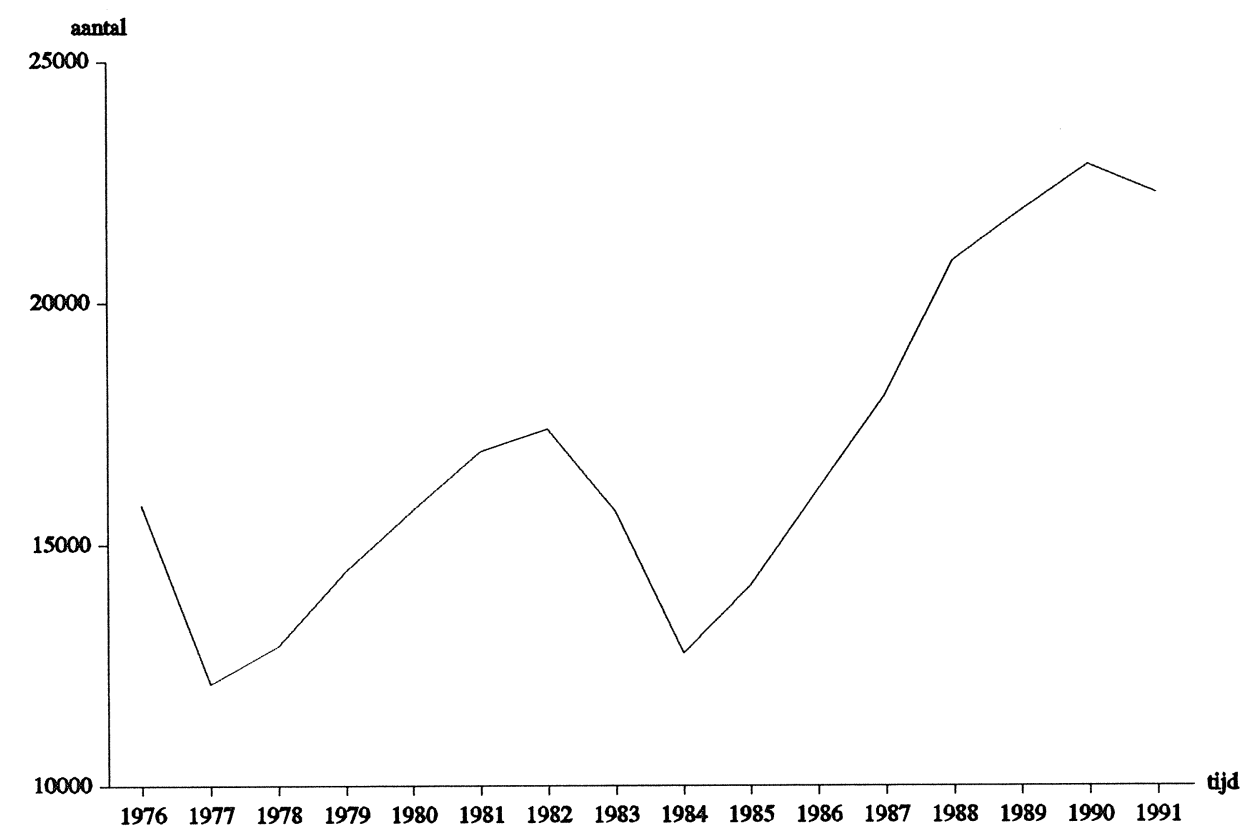

Bron: $\mathrm{CBS} / \mathrm{O} \& \mathrm{~W}$

In tabel 3.1. wordt de ontwikkeling van de totale uitstroom verbijzonderd naar de verschillende landelijke organen. Uit de tabel blijkt dat de ontwikkeling van de uitstroom per landelijk orgaan sterk uiteenloopt. In de periode 1976-1985, waarin de totale gediplomeerde uitstroom van de primaire opleidingen enigszins terug loopt, is de gediplomeerde uitstroom vooral sterk gegroeid bij de SLW. De jaarlijkse groeivoet van de uitstroom van dit landelijk orgaan valt echter vooral ook hoog uit, vanwege de nog zeer geringe uitstroom in 1976. Bij de wat grotere landelijke organen is de gemiddelde jaarlijkse toename van de uitstroom in de jaren 1976-1985 vooral groot bij de VOC (carrosseriebedrijf) $(+6,5 \%)$, de VEV $(+5,1 \%)$ en de OVDB $(+3,9 \%)$. Daarentegen is er in deze periode sprake van een verhoudingsgewijs sterk dalende uitstroom bij de SH\&M $(-6,5 \%)$, de VAPRO $(-5,8 \%)$ en de SOI $(-5,4 \%)$.

Voor de periode 1985-1991 is er vrijwel over de gehele linie sprake van een (zeer) sterk stijgende uitstroom, met als enige uitzondering de VAS (een overigens zeer klein landelijk orgaan). De totale jaarlijkse groei van de gediplomeerde uitstroom van de primaire opleidingen in deze periode is bijna $8 \%$. De sterkste groei doet zich voor bij de ECABO, met een jaarlijkse toename van de gediplomeerde uitstroom van maar liefst $21,1 \%$. Daarnaast is de gemiddelde jaarlijkse groei van de uitstroom in deze periode vooral groot bij de $\operatorname{SLW}(+19,2 \%)$, de OVD $(+18,9 \%)$, de GOC $(+17,2 \%)$ en de SOI $(+15,8 \%)$. Daarentegen blijft bij de SVB $(+4 \%)$ en de SOM $(+5,7 \%)$ de jaarlijkse groei van de uitstroom enigszins achter bij de gemiddelde groei in de periode 1985-1991. 
Tabel 3.1. Gediplomeerde uitstroom van de primaire opleidingen in het leerlingwezen per landelijk orgaan, 1976, 1985 en 1991 (absolute aantallen en gemiddelde jaarlijkse groeivoeten)

\begin{tabular}{|c|c|c|c|c|c|}
\hline $\begin{array}{l}\text { Landelijk } \\
\text { orgaan }\end{array}$ & $\begin{array}{l}1976 \\
\text { aantal }\end{array}$ & $\begin{array}{l}1985 \\
\text { aantal }\end{array}$ & $\begin{array}{l}1991 \\
\text { aantal }\end{array}$ & $\begin{array}{c}\text { groeivoet } \\
1976-1985 \\
\%\end{array}$ & $\begin{array}{c}\text { groeivoet } \\
1985-1991 \\
\%\end{array}$ \\
\hline OVD & 565 & 415 & 1.173 & $-3,4$ & 18,9 \\
\hline ECABO & 350 & 268 & 846 & $-2,9$ & 21,1 \\
\hline SLW & 7 & 216 & 620 & 46,4 & 19,2 \\
\hline SOM & 3.278 & 1.645 & 2.290 & $-7,4$ & 5,7 \\
\hline SVB & 1.481 & 1.431 & 1.807 & $-0,4$ & 4,0 \\
\hline SVS & 573 & 402 & 888 & $-3,9$ & 14,1 \\
\hline INNOVAM & 1.459 & 1.309 & 2.194 & $-1,2$ & 9,0 \\
\hline VBOB & 220 & 152 & 241 & $-4,0$ & 8,0 \\
\hline VEV & 1.583 & 2.486 & 1.450 & 5,1 & $-8,6$ \\
\hline SVGB & 36 & 49 & 111 & 3,5 & 14,6 \\
\hline GOC & 363 & 381 & 986 & 0,5 & 17,2 \\
\hline VOC (conf) & 186 & 136 & 200 & $-3,4$ & 6,6 \\
\hline SVH & 715 & 762 & 1.467 & 0,7 & 11,5 \\
\hline VAS & 19 & 33 & 30 & 6,3 & $-1,6$ \\
\hline VAPRO & 419 & 245 & 534 & $-5,8$ & 13,9 \\
\hline OVDB & 760 & 1.077 & 1.824 & 3,9 & 9,2 \\
\hline SBW & 221 & 268 & 398 & 2,2 & 6,8 \\
\hline VOC (car) & 157 & 312 & 484 & 6,5 & 7,6 \\
\hline BETEX & 18 & 33 & 58 & 7,0 & 9,9 \\
\hline SH\&M & 572 & 312 & 484 & $-6,5$ & 7,6 \\
\hline SVEB & 275 & 325 & 519 & 1,9 & 8,1 \\
\hline SVK & 1.382 & 1.017 & 1.851 & $-3,4$ & 10,5 \\
\hline SVO & 443 & 492 & 831 & 1,2 & 9,1 \\
\hline sol & 755 & 458 & 1.104 & $-5,4$ & 15,8 \\
\hline Totaal & 15.837 & 14.151 & 22.260 & $-1,2$ & 7,8 \\
\hline
\end{tabular}

Bron: CBS/O\&W/ROA

\subsection{Het uitstroommodel van de primaire opleidingen}

Door per landelijk orgaan de jaarlijkse uitstroom van gediplomeerden uit het leerlingwezen te relateren aan de instroom van leerlingen in de voorgaande jaren, kan voor elk landelijk orgaan een beeld worden verkregen van het (longitudinale) interne rendement van de primaire opleidingen. Zoals in de inleiding van dit rapport reeds werd aangegeven, kan uit eerdere studies slechts bij benadering een beeld worden verkregen van het feitelijke interne rendement van de verschillende opleidingen. Om op meer systematische wijze het longitudinale interne rendement van de primaire opleidingen te kunnen bepalen, is door ons met behulp van de beschikbare gegevens over de instroom en uitstroom van leerlingen bij het leerlingwezen het door Lodder, De Grip en Heijke (1992) ontwikkelde model geschat. Op basis van dit uitstroommodel kan het interne rendement en de gemiddelde opleidingsduur van de verschillende opleidingen worden 
vastgesteld.

Omdat de nominale opleidingsduur van de primaire opleidingen twee of drie jaar is, kunnen in principe vijf mogelijkheden worden onderscheiden. Een leerling behaalt zijn diploma na twee of drie jaar, of hij verlaat de opleiding zonder diploma na één, twee of drie jaar. Een bepaald instroomcohort kan derhalve worden opgedeeld in de fracties $P_{g e s l}^{2}$ en $P_{g e s l}^{3}$ voor de geslaagden na respectievelijk twee en drie jaar, en $P_{\text {uitv }}^{1}, P_{\text {uitv }}^{2}$ en $P_{\text {uitv }}^{3}$ voor de uitvallers na respectievelijk een, twee en drie jaar. Deze vijf fracties moeten per definitie samen optellen tot 1 . Het te schatten model luidt als volgt:

$$
\begin{aligned}
& G_{l}^{t}=P_{g e s l, l}^{2} N^{t-2}+P_{g e s, l}^{3} N^{t-3}+\epsilon_{g e s l, l}^{t} \\
& U_{l}^{t}=P_{u i t v, l}^{1} N^{t-1}+P_{u i t, l}^{2} N^{t-2}+P_{u i t v, l}^{3} N^{t-3}+\epsilon_{u i t v, l}^{t}
\end{aligned}
$$

waarbij:

$$
\begin{array}{ll}
G_{l}^{t} & =\text { het aantal geslaagden bij de primaire opleidingen van orgaan } l \text { in jaar } \mathrm{t} ; \\
N_{l}^{t} & =\text { het aantal leerlingen dat in jaar } t \text { instroomt in het primaire leerlingwezen bij orgaan } l ; \\
U_{l}^{t} & =\text { het aantal uitvallers bij de primaire opleidingen van orgaan } l \text { in jaar } t,
\end{array}
$$

met de restrictie:

$P_{g e s l, l}^{2}+P_{g e s, l}^{3}+P_{u i t v, l}^{1}+P_{u i t v, l}^{2}+P_{u i v, l}^{3}=1$.

Deze parameterrestrictie leidt tot de volgende specificatie:

$G_{l}^{t}=P_{g e s l, l}^{2} N_{l}^{t-2}+P_{g e s l, l}^{3} N_{l}^{t-3}+\varepsilon_{g e s l, l}^{t}$

$U_{l}^{t}=P_{u i t v, l}^{1} N_{l}^{t-1}+P_{u i t v, l}^{2} N_{l}^{t-2}+\left(1-P_{g e s l, l}^{2}-P_{g e s l, l}^{3}-P_{u i t v, l}^{1}-P_{u i v v, l}^{2}\right) N_{l}^{t-3}+\epsilon_{u i v, l}^{t}$

Vanwege de onderlinge samenhang in de parameters van beide vergelijkingen en vanwege mogelijke samenhang van de storingstermen $\varepsilon_{\text {ges }, l}^{t}$ en $\varepsilon_{u \text { utv, } l}^{t}$ is dit model geschat volgens het Seemingly Unrelated Regressions Model (SUR). Daar deze schattingsmethode niet garandeert dat de parameters tussen 0 en 1 liggen, was het nodig om bij enkele organen deze restrictie op te leggen. Hiertoe is stapsgewijs steeds van de parameters die niet aan de randvoorwaarde voldoen, die parameter vastgezet op de randwaarde die in de schatting de hoogste t-waarde heeft, waarna het model opnieuw wordt geschat. Deze procedure wordt herhaald totdat alle parameters aan de randvoorwaarden voldoen.

In feite worden alleen de eerste vier uitstroomfracties geschat. De vijfde fractie volgt uit deze schattingen:

$P_{u i t v, l}^{3}=1-P_{g e s, l}^{2}-P_{g e s l, l}^{3}-P_{u i t v, l}^{1}-P_{u i t v, l}^{2}$ 
Voor het rendement en het uitvalspercentage geldt:

rend $_{l}=P_{\text {gesl, }, l}^{2}+P_{\text {gesl }, l}^{3}$

uitval $_{l}=1-$ rend $_{l}$

waarbij:

rend $_{l}=$ het rendement van de primaire opleidingen van orgaan $l$;

uival $_{l}=$ het uitvalspercentage van de primaire opleidingen van orgaan $l$.

De duurvariabelen zijn als volgt berekend:

$$
\begin{aligned}
& \text { duur }_{\text {gesl, }, l}=\frac{2 P_{\text {gesl },}^{2}+3 P_{\text {gesl }, l}^{3}}{P_{\text {ges }, l}^{2}+P_{\text {ges }, l}^{3}} \\
& \text { duur }_{u i t v, l}=\frac{P_{u i v, l}^{1}+2 P_{u i v, l}^{2}+3 P_{u i v, l}^{3}}{P_{u i t v, l}^{1}+P_{u i t v, l}^{2}+P_{u i t v, l}^{3}}
\end{aligned}
$$

waarbij:

$$
\begin{aligned}
\text { duur }_{\text {gesl }, l}= & \text { de gemiddelde opleidingsduur van de geslaagden bij de primaire opleidingen } \\
& \text { van orgaan } l \\
\text { duur }_{\text {uitv, }, l}= & \text { de gemiddelde verblijfsduur van de uitvallers bij de primaire opleidingen van } \\
& \text { orgaan } l .
\end{aligned}
$$

De fractie leerlingen die reeds na een jaar uitvalt is ten slotte als volgt gedefinieerd:

$f r_{u i t v, l}^{1}=\frac{P_{u i t v, l}^{1}}{P_{u i t, l}^{1}+P_{u i t v, l}^{2}+P_{u i t v, l}^{3}}$

waarbij:

$f r_{u i t, l}^{1}=$ de fractie leerlingen bij de primaire opleidingen van orgaan $l$ die reeds na een jaar. uitvalt.

Tabel 3.2. geeft een overzicht van de schattingsresultaten van het uitstroommodel van de primaire opleidingen voor de periode 1980-1991, verbijzonderd naar de 24 onderscheiden organen. Onder de parameterwaarden staan telkens de bijbehorende schattingsfouten. Omdat bij het vastzetten van parameters er geen standaardfouten geschat kunnen worden, zijn alle in tabel 3.2. vermelde standaardfouten gebaseerd op het ongerestricteerde model. Het blijkt overigens dat de restricties vrijwel geen invloed hebben op de rendementscijfers. De schattingen van het precieze jaar waarin leerlingen uitstromen worden hierdoor echter wel beïnvloed. In het algemeen blijkt dat de schattingen met betrekking tot het totaal aantal leerlingen dat slaagt of uitvalt betrouwbaarder zijn dan de schattingen over het exacte jaar van slagen of uitvallen. Overigens blijken de rendementscijfers niet erg gevoelig te zijn voor de preciese specificatie van het model. De geschatte rendementscijfers zijn derhalve zeer robuust. 
$-45-$

Tabel 3.2. Schattingsresultaten geslaagden en uitvallers per jaar per landelijk orgaan, 1980-1991 (standaardfouten tussen haakjes)

\begin{tabular}{|c|c|c|c|c|c|}
\hline $\begin{array}{l}\text { Landelijk } \\
\text { orgaan }\end{array}$ & $p_{\text {gest }}^{2}$ & $p_{\text {gest }}^{8}$ & $p_{\text {uivv }}^{1}$ & $p_{u i v v}^{2}$ & $p_{\text {uivv }}^{3}$ \\
\hline OVD & $\begin{array}{c}0,14 \\
(0,08)\end{array}$ & $\begin{array}{c}0,26 \\
(0,08)\end{array}$ & $\begin{array}{c}0,51 \\
(0,10)\end{array}$ & $\begin{array}{c}0,10 \\
(0,18)\end{array}$ & $\begin{array}{c}0,00 \\
(0,16)\end{array}$ \\
\hline ECABO & $\begin{array}{c}0,26 \\
(0,10)\end{array}$ & $\begin{array}{c}0,16 \\
(0,11)\end{array}$ & $\begin{array}{c}0,22 \\
(0,09)\end{array}$ & $\begin{array}{c}0,17 \\
(0,13)\end{array}$ & $\begin{array}{c}0,19 \\
(0,11)\end{array}$ \\
\hline SLW & $\begin{array}{c}0,45 \\
(0,13)\end{array}$ & $\begin{array}{c}0,20 \\
(0,14)\end{array}$ & $\begin{array}{c}0,00 \\
(0,22)\end{array}$ & $\begin{array}{c}0,17 \\
(0,23)\end{array}$ & $\begin{array}{c}0,17 \\
(0,21)\end{array}$ \\
\hline SOM & $\begin{array}{c}0,13 \\
(0,15)\end{array}$ & $\begin{array}{c}0,47 \\
(0,15)\end{array}$ & $\begin{array}{c}0,08 \\
(0,10)\end{array}$ & $\begin{array}{c}0,30 \\
(0,14)\end{array}$ & $\begin{array}{c}0,02 \\
(0,11)\end{array}$ \\
\hline SVB & $\begin{array}{c}0,32 \\
(0,08)\end{array}$ & $\begin{array}{c}0,18 \\
(0,08)\end{array}$ & $\begin{array}{c}0,15 \\
(0,14)\end{array}$ & $\begin{array}{c}0,32 \\
(0,20)\end{array}$ & $\begin{array}{c}0,03 \\
(0,12)\end{array}$ \\
\hline svs & $\begin{array}{c}0,23 \\
(0,08)\end{array}$ & $\begin{array}{c}0,30 \\
(0,09)\end{array}$ & $\begin{array}{c}0,31 \\
(0,07)\end{array}$ & $\begin{array}{l}0,00 \\
(0,10)\end{array}$ & $\begin{array}{c}0,16 \\
(0,08)\end{array}$ \\
\hline INNOVAM & $\begin{array}{c}0,23 \\
(0,08)\end{array}$ & $\begin{array}{c}0,36 \\
(0,08)\end{array}$ & $\begin{array}{c}0,11 \\
(0,11)\end{array}$ & $\begin{array}{c}0,13 \\
(0,13)\end{array}$ & $\begin{array}{c}0,17 \\
(0,11)\end{array}$ \\
\hline VBOB & $\begin{array}{c}0,27 \\
(0,11)\end{array}$ & $\begin{array}{c}0,35 \\
(0,11)\end{array}$ & $\begin{array}{c}0,11 \\
(0,07)\end{array}$ & $\begin{array}{c}0,13 \\
(0,11)\end{array}$ & $\begin{array}{c}0,14 \\
(0,08)\end{array}$ \\
\hline VEV & $\begin{array}{c}0,23 \\
(0,13)\end{array}$ & $\begin{array}{c}0,15 \\
(0,14)\end{array}$ & $\begin{array}{c}0,00 \\
(0,14)\end{array}$ & $\begin{array}{c}0,28 \\
(0,19)\end{array}$ & $\begin{array}{c}0,34 \\
(0,18)\end{array}$ \\
\hline SVGB & $\begin{array}{c}0,33 \\
(0,17)\end{array}$ & $\begin{array}{c}0,10 \\
(0,18)\end{array}$ & $\begin{array}{c}0,00 \\
(0,10)\end{array}$ & $\begin{array}{c}0,51 \\
(0,26)\end{array}$ & $\begin{array}{c}0,06 \\
(0,21)\end{array}$ \\
\hline GOC & $\begin{array}{c}0,35 \\
(0,09)\end{array}$ & $\begin{array}{c}0,33 \\
(0,09)\end{array}$ & $\begin{array}{c}0,04 \\
(0,08)\end{array}$ & $\begin{array}{c}0,22 \\
(0,12)\end{array}$ & $\begin{array}{c}0,06 \\
(0,09)\end{array}$ \\
\hline VOC (conf) & $\begin{array}{c}0,22 \\
(0,04)\end{array}$ & $\begin{array}{c}0,22 \\
(0,03)\end{array}$ & $\begin{array}{c}0,31 \\
(0,11)\end{array}$ & $\begin{array}{c}0,17 \\
(0,07)\end{array}$ & $\begin{array}{c}0,08 \\
(0,10)\end{array}$ \\
\hline SVH & $\begin{array}{c}0,34 \\
(0,13)\end{array}$ & $\begin{array}{c}0,18 \\
(0,14)\end{array}$ & $\begin{array}{c}0,35 \\
(0,17)\end{array}$ & $\begin{array}{c}0,00 \\
(0,20)\end{array}$ & $\begin{array}{c}0,13 \\
(0,17)\end{array}$ \\
\hline VAS & $\begin{array}{c}0,32 \\
(0,16)\end{array}$ & $\begin{array}{c}0,22 \\
(0,17)\end{array}$ & $\begin{array}{c}0,46 \\
(0,13)\end{array}$ & $\begin{array}{c}0,00 \\
(0,21)\end{array}$ & $\begin{array}{c}0,00 \\
(0,14)\end{array}$ \\
\hline VAPRO & $\begin{array}{c}0,41 \\
(0,10)\end{array}$ & $\begin{array}{c}0,11 \\
(0,10)\end{array}$ & $\begin{array}{c}0,12 \\
(0,06)\end{array}$ & $\begin{array}{c}0,27 \\
(0,07)\end{array}$ & $\begin{array}{c}0,08 \\
(0,06)\end{array}$ \\
\hline OVDB & $\begin{array}{c}0,61 \\
(0,12)\end{array}$ & $\begin{array}{c}0,06 \\
(0,12)\end{array}$ & $\begin{array}{c}0,09 \\
(0,10)\end{array}$ & $\begin{array}{c}0,06 \\
(0,12)\end{array}$ & $\begin{array}{c}0,18 \\
(0,10)\end{array}$ \\
\hline SBW & $\begin{array}{c}0,25 \\
(0,08)\end{array}$ & $\begin{array}{c}0,22 \\
(0,08)\end{array}$ & $\begin{array}{c}0,25 \\
(0,06)\end{array}$ & $\begin{array}{c}0,21 \\
(0,07)\end{array}$ & $\begin{array}{c}0,07 \\
(0,07)\end{array}$ \\
\hline VOC (car) & $\begin{array}{c}0,32 \\
(0,18)\end{array}$ & $\begin{array}{c}0,15 \\
(0,20)\end{array}$ & $\begin{array}{c}0,37 \\
(0,42)\end{array}$ & $\begin{array}{c}0,00 \\
(0,50)\end{array}$ & $\begin{array}{c}0,16 \\
(0,40)\end{array}$ \\
\hline BETEX & $\begin{array}{c}0,45 \\
(0,08)\end{array}$ & $\begin{array}{c}0,15 \\
(0,08)\end{array}$ & $\begin{array}{c}0,13 \\
(0,11)\end{array}$ & $\begin{array}{c}0,26 \\
(0,08)\end{array}$ & $\begin{array}{c}0,00 \\
(0,11)\end{array}$ \\
\hline SH\&M & $\begin{array}{c}0,36 \\
(0,07)\end{array}$ & $\begin{array}{c}0,11 \\
(0,07)\end{array}$ & $\begin{array}{c}0,26 \\
(0,19)\end{array}$ & $\begin{array}{c}0,24 \\
(0,23)\end{array}$ & $\begin{array}{c}0,03 \\
(0,19)\end{array}$ \\
\hline SVEB & $\begin{array}{c}0,65 \\
(0,20)\end{array}$ & $\begin{array}{c}0,00 \\
(0,20)\end{array}$ & $\begin{array}{c}0,35 \\
(0,19)\end{array}$ & $\begin{array}{c}0,00 \\
(0,29)\end{array}$ & $\begin{array}{c}0,00 \\
(0,21)\end{array}$ \\
\hline SVK & $\begin{array}{c}0,40 \\
(0,11)\end{array}$ & $\begin{array}{c}0,20 \\
(0,11)\end{array}$ & $\begin{array}{c}0,24 \\
(0,07)\end{array}$ & $\begin{array}{c}0,12 \\
(0,09)\end{array}$ & $\begin{array}{c}0,03 \\
(0,08)\end{array}$ \\
\hline Svo & $\begin{array}{c}0,27 \\
(0,12)\end{array}$ & $\begin{array}{c}0,37 \\
(0,12)\end{array}$ & $\begin{array}{c}0,14 \\
(0,20)\end{array}$ & $\begin{array}{c}0,00 \\
(0,28)\end{array}$ & $\begin{array}{c}0,23 \\
(0,21)\end{array}$ \\
\hline SOI & $\begin{array}{c}1,121 \\
0,24 \\
(0,00)\end{array}$ & $\begin{array}{c}0,24 \\
0,24 \\
(0,00)\end{array}$ & $\begin{array}{c}0,17 \\
(0,00)\end{array}$ & $\begin{array}{c}0,00 \\
0,00) \\
(0,00)\end{array}$ & $\begin{array}{c}0,35 \\
(0,00)\end{array}$ \\
\hline
\end{tabular}

Bron: ROA 
Tabel 3.3. Schattingsresultaten intern rendement en uitvalpercentage, gemiddelde verblijfsduur van geslaagden en uitvallers; en het aandeel van de leerlingen dat reeds na een jaar uitvalt, per landelijk orgaan, 1980-1991 (standaardfouten tussen haakjes)

\begin{tabular}{|c|c|c|c|c|c|}
\hline $\begin{array}{l}\text { Landelijk } \\
\text { orgaan }\end{array}$ & $\begin{array}{l}\text { intern } \\
\text { rendement }\end{array}$ & $\begin{array}{l}\text { uitval- } \\
\text { percentage }\end{array}$ & $\begin{array}{l}\text { opleidingsduur } \\
\text { geslaagden } \\
\text { (jaren) }\end{array}$ & $\begin{array}{l}\text { verblijfsduur } \\
\text { uitvallers } \\
\text { (jaren) }\end{array}$ & $\begin{array}{l}\text { fractie } \\
\text { uitval } \\
\text { jaar } 1\end{array}$ \\
\hline OVD & $\begin{array}{c}0,40 \\
(0,01)\end{array}$ & $\begin{array}{c}0,60 \\
(0,01)\end{array}$ & 2,66 & 1,16 & 0,84 \\
\hline ECABO & $\begin{array}{c}0,43 \\
(0,05)\end{array}$ & $\begin{array}{c}0,57 \\
(0,05)\end{array}$ & 2,38 & 1,96 & 0,38 \\
\hline SLW & $\begin{array}{c}0,65 \\
(0,03)\end{array}$ & $\begin{array}{c}0,35 \\
(0,03)\end{array}$ & 2,31 & 2,50 & 0,00 \\
\hline SOM & $\begin{array}{c}0,60 \\
(0,01)\end{array}$ & $\begin{array}{c}0,40 \\
(0,01)\end{array}$ & 2,78 & 1,84 & 0,21 \\
\hline SVB & $\begin{array}{c}0,50 \\
(0,01)\end{array}$ & $\begin{array}{c}0,50 \\
(0,01)\end{array}$ & 2,36 & 1,77 & 0,29 \\
\hline svs & $\begin{array}{c}0,53 \\
(0,01)\end{array}$ & $\begin{array}{c}0,47 \\
(0,01)\end{array}$ & 2,56 & 1,67 & 0,67 \\
\hline INNOVAM & $\begin{array}{c}0,59 \\
(0,02)\end{array}$ & $\begin{array}{c}0,41 \\
(0,02)\end{array}$ & 2,61 & 2,13 & 0,28 \\
\hline VBOB & $\begin{array}{c}0,62 \\
(0,01)\end{array}$ & $\begin{array}{c}0,38 \\
(0,01)\end{array}$ & 2,56 & 2,10 & 0,28 \\
\hline VEV & $\begin{array}{c}0,38 \\
(0,02)\end{array}$ & $\begin{array}{c}0,62 \\
(0,02)\end{array}$ & 2,40 & 2,54 & 0,00 \\
\hline SVGB & $\begin{array}{c}0,43 \\
(0,03)\end{array}$ & $\begin{array}{c}0,57 \\
(0,03)\end{array}$ & 2,23 & 2,10 & 0,00 \\
\hline GOC & $\begin{array}{c}0,68 \\
(0,01)\end{array}$ & $\begin{array}{c}0,32 \\
(0,01)\end{array}$ & 2,49 & 2,06 & 0,13 \\
\hline VOC (conf) & $\begin{array}{c}0,44 \\
(0,02)\end{array}$ & $\begin{array}{c}0,56 \\
(0,02)\end{array}$ & 2,50 & 1,60 & 0,55 \\
\hline SVH & $\begin{array}{c}0,52 \\
(0,03)\end{array}$ & $\begin{array}{c}0,48 \\
(0,03)\end{array}$ & 2,35 & 1,53 & 0,74 \\
\hline VAS & $\begin{array}{c}0,54 \\
(0,03)\end{array}$ & $\begin{array}{c}0,46 \\
(0,03)\end{array}$ & 2,41 & 1,00 & 1,00 \\
\hline VAPRO & $\begin{array}{l}0,53 \\
0,03\end{array}$ & $\begin{array}{l}0,48 \\
0,03\end{array}$ & 2,21 & 1,91 & 0,26 \\
\hline OVDB & $\begin{array}{c}0,67 \\
(0,02)\end{array}$ & $\begin{array}{c}0,33 \\
(0,02)\end{array}$ & 2,09 & 2,26 & 0,28 \\
\hline SBW & $\begin{array}{c}0,47 \\
(0,01)\end{array}$ & $\begin{array}{c}0,53 \\
(0,01)\end{array}$ & 2,47 & 1,67 & 0,47 \\
\hline VOC (car) & $\begin{array}{c}0,47 \\
(0,06)\end{array}$ & $\begin{array}{c}0,53 \\
(0,06)\end{array}$ & 2,32 & 1,59 & 0,71 \\
\hline BETEX & $\begin{array}{c}0,61 \\
(0,03)\end{array}$ & $\begin{array}{c}0,39 \\
(0,03)\end{array}$ & 2,25 & 1,66 & 0,34 \\
\hline SH\&M & $\begin{array}{c}0,47 \\
(0,01)\end{array}$ & $\begin{array}{c}0,53 \\
(0,01)\end{array}$ & 2,23 & 1,56 & 0,49 \\
\hline SVEB & $\begin{array}{c}0,65 \\
(0,01)\end{array}$ & $\begin{array}{c}0,35 \\
(0,01)\end{array}$ & 2,00 & 1,00 & 1,00 \\
\hline SVK & $\begin{array}{c}0,60 \\
(0,02)\end{array}$ & $\begin{array}{c}0,40 \\
(0,02)\end{array}$ & 2,34 & 1,48 & 0,60 \\
\hline SVO & $\begin{array}{c}0,64 \\
(0,02)\end{array}$ & $\begin{array}{c}0,36 \\
(0,02)\end{array}$ & 2,58 & 2,25 & 0,37 \\
\hline sOI & $\begin{array}{c}0,48 \\
(0,00)\end{array}$ & $\begin{array}{c}0,52 \\
(0,00)\end{array}$ & 2,49 & 2,36 & 0,32 \\
\hline
\end{tabular}

Bron: ROA 
Tabel 3.3. geeft een samenvattend overzicht van de schattingsresultaten, toegespitst op het interne rendement, het uitvalspercentage, de gemiddelde verblijfsduur van geslaagden en uitvallers en het aandeel van de leerlingen dat reeds na 1 jaar uitvalt. Omdat de restricties weinig invloed hebben op de rendementsschattingen zijn de verschillende ratio's in deze tabel gebaseerd op de ongerestricteerde schattingen. Dit maakt het mogelijk om de standaardfouten van de rendementscijfers en de uitvalpercentages te berekenen op basis van de covariantiematrix van de geschatte parameters. Omdat bij de verblijfsduur en de fractie uitval na 1 jaar het verband met de parameters niet-lineair is, is hierbij een schatting van de standaardfout achterwege gelaten.

In de tabel staan ook de schattingen van de gemiddelde verblijfsduur van de leerlingen die uiteindelijk slagen en van de leerlingen die uitvallen. Bij de SVEB (2,00 jaar) en bij de OVDB $(2,09$ jaar) is de gemiddelde opleidingsduur van de leerlingen die slagen erg laag. Bij de SOM $(2,78$ jaar) en de OVD $(2,66$ jaar $)$ is de opleidingsduur van de geslaagden daarentegen zeer hoog. Ook bij de uitvallers is de verblijfsduur bij de SVEB (1,00 jaar) erg laag, zodat dit orgaan op alle fronten goede prestaties levert. Verder zijn bij de VAS $(1,00$ jaar) en bij de OVD 11,16 jaar) de verblijfsduren van de uitvallers laag. Gezien de lange opleidingsduur van de leerlingen die slagen, is men er bij dit laatstgenoemde orgaan kennelijk toe in staat de uitvallers snel te scheiden van de succesvolle leerlingen. Een hoge gemiddelde verblijfsduur van de uitvallers wordt gevonden bij de VEV (2,54 jaar) en de SLW (2,50 jaar). Bij de VEV duidde ook het lage en bovendien dalende rendement reeds op een relatief slechte performance van dit landelijk orgaan.

Figuur 3.2. laat zien dat het interne rendement van de primaire opleidingen van de verschillende organen tussen de $38 \%$ en $68 \%$ ligt. Het laagste rendement doet zich voor bij de VEV $(38 \%)$, terwijl ook de OVD (40\%), de ECABO (43\%) en de SVGB $(43 \%)$ een zeer laag rendement hebben. Het hoogste interne rendement is te vinden bij de GOC (68\%). Ook bij de OVDB (67\%), de SLW $(65 \%)$ en de SVEB $(65 \%)$ is het rendement relatief hoog. 
Figuur 3.2. Rendementen per landelijk orgaan.

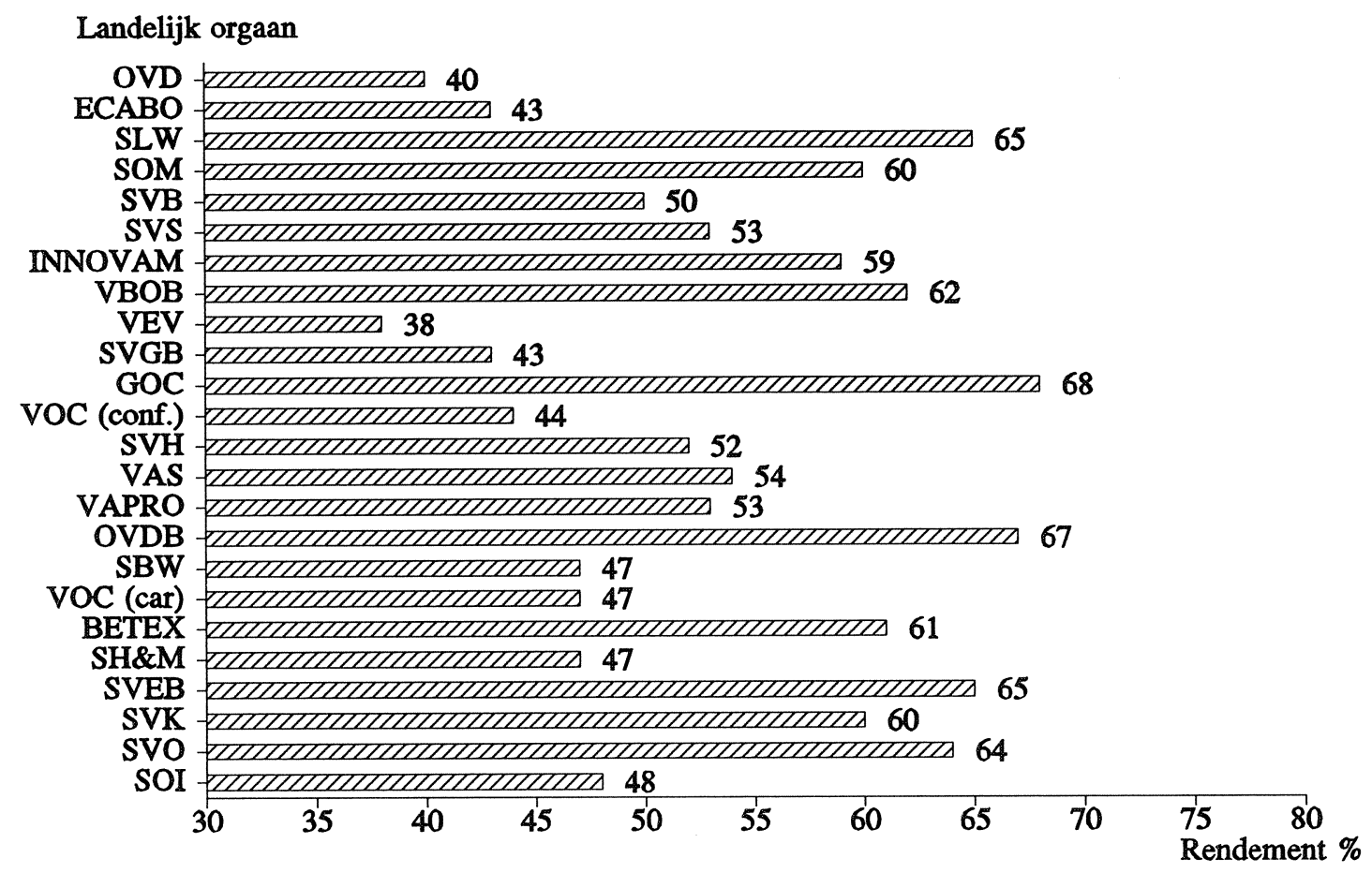

Bron: ROA

De schattingen in tabel 3.2. zijn gebaseerd op de veronderstelling dat het rendement in de periode 1980-1991 constant is gebleven. Vanwege de beleidsveranderingen die met name in de eerste helft van de jaren tachtig zijn ingezet, is het interessant om na te gaan of er in de loop van de jaren tachtig, mogelijk mede door deze beleidswijzigingen, een substantiële verandering van het rendement heeft plaatsgevonden. Hiertoe zijn de rendementspercentages ook geschat voor twee deelperiodes: 1980-1985 en 1986-1991. Tabel 3.4. bevat de rendementscijfers voor beide periodes, waarbij ook wordt aangegeven of de waargenomen verschillen statistisch significant zijn. Uit de tabel blijkt dat er in 11 van de 24 gevallen sprake is van een significante verandering van het rendement. In 8 van de 11 gevallen gaat het om een verbetering van het rendement, terwijl bij 3 landelijke organen het interne rendement is verslechterd. Per saldo is er de laatste jaren derhalve sprake van een lichte verbetering van het interne rendement. Dit komt ook tot uitdrukking in de figuren 3.3. en 3.4., waarin de verdeling van de rendementen in de beide subperioden wordt weergegeven. 
Tabel 3.4. Schattingsresultaten intern rendement in de perioden 1980-1985 en 1986-1991 (standaardfouten tussen haakjes), het verschil tussen beide schattingen en de statistische significantie van dit verschil

\begin{tabular}{|c|c|c|c|c|c|}
\hline $\begin{array}{l}\text { Landelijk } \\
\text { orgaan }\end{array}$ & $\begin{array}{l}\text { rendement } \\
80-85\end{array}$ & $\begin{array}{l}\text { rendement } \\
86-91\end{array}$ & verschil & $\mathrm{t}$-waarde & significant? \\
\hline OVD & $\begin{array}{c}0,41 \\
(0,01)\end{array}$ & $\begin{array}{c}0,43 \\
(0,03)\end{array}$ & $\begin{array}{c}0,02 \\
(0,03)\end{array}$ & 0,50 & nee \\
\hline \multirow[t]{2}{*}{ ECABO } & 0,44 & 0,41 & $-0,03$ & & \\
\hline & $(0,01)$ & $(0,08)$ & $(0,08)$ & 0,33 & nee \\
\hline \multirow[t]{2}{*}{ SLW } & 0,61 & 0,62 & 0,01 & & \\
\hline & $(0,03)$ & $(0,04)$ & $(0,05)$ & 0,20 & nee \\
\hline \multirow[t]{2}{*}{ SOM } & 0,64 & 0,57 & $-0,07$ & & \\
\hline & $(0,01)$ & $(0,01)$ & $(0,01)$ & 6,50 & ja: daling \\
\hline \multirow[t]{2}{*}{ SVB } & 0,48 & 0,55 & 0,07 & & \\
\hline & $(0,01)$ & $(0,01)$ & $(0,02)$ & 3,78 & ja: stijging \\
\hline \multirow[t]{2}{*}{ SVS } & 0,48 & 0,53 & 0,05 & & \\
\hline & $(0,01)$ & $(0,02)$ & $(0,02)$ & 2,19 & ja: stijging \\
\hline \multirow[t]{2}{*}{ INNOVAM } & 0,58 & 0,62 & 0,04 & & \\
\hline & $(0,03)$ & $(0,02)$ & $(0,04)$ & 1,00 & nee \\
\hline \multirow[t]{2}{*}{ VBOB } & 0,60 & 0,63 & 0,03 & & \\
\hline & $(0,01)$ & $(0,02)$ & $(0,02)$ & 1,20 & nee \\
\hline \multirow[t]{2}{*}{ VEV } & 0,44 & 0,34 & $-0,11$ & & \\
\hline & $(0,02)$ & $(0,02)$ & $(0,02)$ & 4,62 & ja: daling \\
\hline \multirow{2}{*}{ SVGB } & 0,43 & 0,40 & $-0,03$ & & \\
\hline & $(0,05)$ & $(0,04)$ & $(0,07)$ & 0,50 & nee \\
\hline \multirow[t]{2}{*}{ GOC } & 0,67 & 0,68 & 0,02 & & \\
\hline & $(0,02)$ & $(0,02)$ & $(0,03)$ & 0,62 & nee \\
\hline \multirow[t]{2}{*}{ VOC (conf) } & 0,45 & 0,42 & $-0,03$ & & \\
\hline & $(0,03)$ & $(0,02)$ & $(0,03)$ & 0,81 & nee \\
\hline \multirow[t]{2}{*}{ SVH } & 0,44 & 0,58 & 0,14 & & \\
\hline & $(0,02)$ & $(0,02)$ & $(0,03)$ & 5,44 & ja: stijging \\
\hline \multirow[t]{2}{*}{ VAS } & 0,47 & 0,59 & 0,12 & & \\
\hline & $(0,04)$ & $(0,02)$ & $(0,05)$ & 2,49 & ja: stijging \\
\hline \multirow[t]{2}{*}{ VAPRO } & 0,56 & 0,51 & $-0,05$ & & \\
\hline & $(0,01)$ & $(0,04)$ & $(0,04)$ & 1,19 & nee \\
\hline \multirow[t]{2}{*}{ OVDB } & 0,71 & 0,62 & $-0,09$ & & \\
\hline & $(0,00)$ & $(0,02)$ & $(0,02)$ & 5,92 & ja: daling \\
\hline \multirow[t]{2}{*}{ SBW } & 0,45 & 0,49 & 0,05 & & \\
\hline & $(0,01)$ & $(0,02)$ & $(0,02)$ & 2,17 & ja: stijging \\
\hline \multirow[t]{2}{*}{ VOC (car) } & 0,52 & 0,42 & $-0,10$ & & \\
\hline & $(0,03)$ & $(0,10)$ & $(0,10)$ & 0,98 & nee \\
\hline \multirow[t]{2}{*}{ BETEX } & 0,48 & 0,63 & 0,16 & & \\
\hline & $(0,04)$ & $(0,04)$ & $(0,05)$ & 2,96 & ja: stijging \\
\hline \multirow[t]{2}{*}{ SH\&M } & 0,43 & 0,50 & 0,08 & & \\
\hline & $(0,02)$ & $(0,01)$ & $(0,03)$ & 2,93 & ja: stijging \\
\hline \multirow[t]{2}{*}{ SVEB } & 0,62 & 0,67 & 0,05 & & \\
\hline & $(0,01)$ & $(0,01)$ & $(0,01)$ & 3,45 & ja: stijging \\
\hline \multirow[t]{2}{*}{ SVK } & 0,63 & 0,64 & 0,01 & & \\
\hline & $(0,02)$ & $(0,03)$ & $(0,03)$ & 0,30 & nee \\
\hline svo & 0,61 & 0,68 & 0,07 & & \\
\hline & $(0,02)$ & $(0,03)$ & $(0,04)$ & 1,84 & nee \\
\hline SOI & 0,49 & 0,49 & 0,00 & & \\
\hline & $(0,01)$ & $(0,04)$ & $(0,04)$ & 0,05 & nee \\
\hline
\end{tabular}

Bron: ROA 
Figuur 3.3. Verdeling rendementen 1980-1985 per orgaan over 10\% klassen.

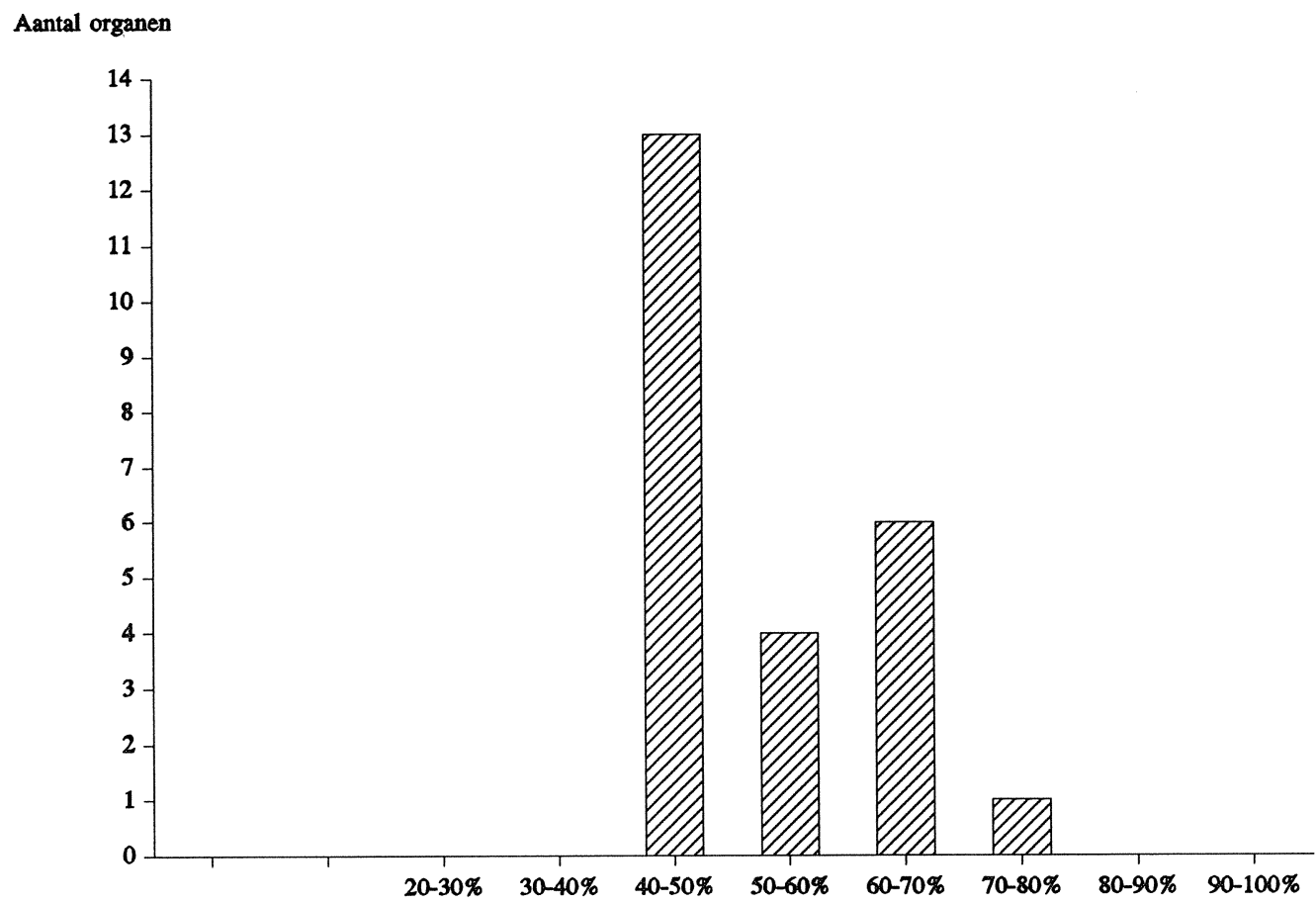

Bron: ROA

Figuur 3.4. Verdeling rendementen 1986-1991 per orgaan over 10\% klassen.

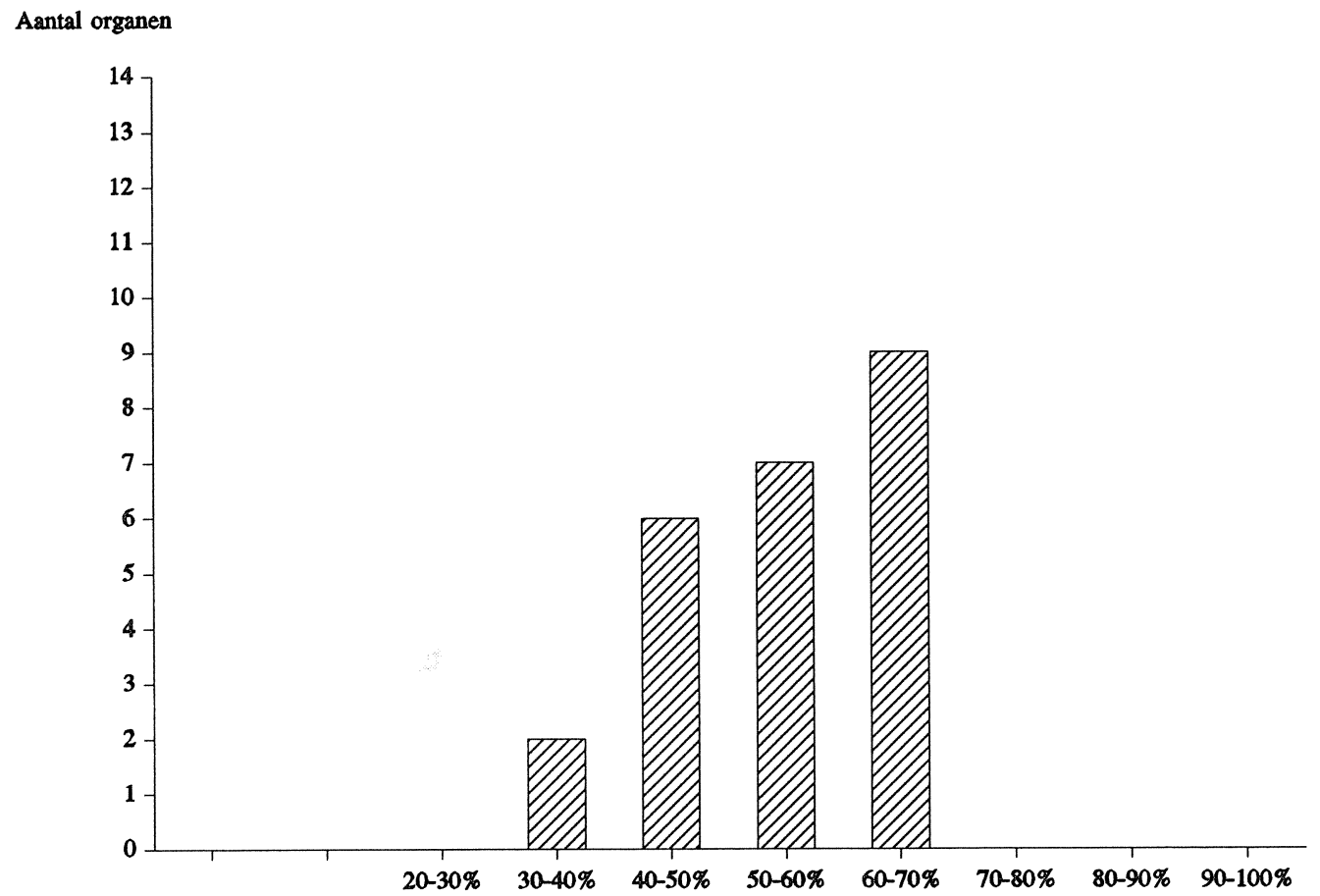

Bron: ROA 
Tabel 3.5. geeft een overzicht van de landelijke organen met een significante daling of een significante stijging van het interne rendement. De grootste achteruitgang in het rendement vond plaats bij de VEV, waar het rendement van $44 \%$ naar $34 \%$ is gezakt. Temeer daar de VEV toch al het orgaan was met het laagste interne rendement, is deze rendementsdaling zonder meer verontrustend te noemen. Bij de drie andere organen met een laag rendement heeft er in de loop van de jaren tachtig geen significante verandering van het interne rendement plaatsgevonden. Bij de OVDB, een orgaan dat een relatief hoog rendement kent, is het rendement met 9 procent-punten achteruit gegaan van $71 \%$ naar $62 \%$. Bij de SOM daalde het rendement 7 procentpunten van $64 \%$ naar $57 \%$. Daarentegen is er bij de SVEB waar het rendement toch al vrij hoog was, sprake van een toename van het interne rendement met 5 procentpunten (van $62 \%$ naar $67 \%$ ).

Tabel 3.5. Landelijke organen met een significante daling of stijging van het interne rendement (19861991 t.o.v. 1980-1985)

\begin{tabular}{llll}
\hline $\begin{array}{l}\text { Landelijk } \\
\text { orgaan }\end{array}$ & $\begin{array}{l}\text { dalend } \\
\text { rendement } \\
\text { \%-punt }\end{array}$ & $\begin{array}{l}\text { landelijk } \\
\text { orgaan }\end{array}$ & $\begin{array}{l}\text { stijgend } \\
\text { rendement } \\
\% \text {-punt }\end{array}$ \\
\hline VEV & -11 & BETEX & 16 \\
OVDB & -9 & SVH & 14 \\
SOM & -7 & VAS & 12 \\
& & SH\&M & 8 \\
& SVB & 7 \\
& SVS & 5 \\
& SBW & 5 \\
& SVEB & 5 \\
\hline
\end{tabular}

Bron: ROA

\subsection{Verwachte uitstroom gediplomeerden van de primaire opleidingen 1993-2001}

Op basis van de schattingsresultaten van het rendement van de primaire opleidingen van de verschillende landelijke organen kunnen de prognoses van de leerlingeninstroom worden vertaald naar prognoses van de uitstroom van gediplomeerden, verbijzonderd naar landelijk orgaan. In het basisscenario wordt daarbij uitgegaan van de schattingsresultaten van het uitstroommodel over de gehele periode 1980-1991. Met andere woorden: er wordt verondersteld dat er geen verandering zal optreden in het interne rendement dat de verschillende landelijke organen weten te realiseren.

Tabel 3.6. geeft een overzicht van de prognoseresultaten van de gediplomeerde uitstroom per landelijk orgaan voor de jaren 1997 en 2001. Ter vergelijking is in de tabel ook de gediplomeerde uitstroom in het jaar 1991 opgenomen. Voor een volledig overzicht van de uitstroomprognoses over alle prognosejaren wordt verwezen naar bijlage $\mathrm{F}$. 
Tabel 3.6. Verwachte gediplomeerde uitstroom van de primaire opleidingen in het leerlingwezen per landelijk orgaan volgens het basisscenario, 1997 en 2001 (absolute aantallen)

\begin{tabular}{|c|c|c|c|}
\hline $\begin{array}{l}\text { Landelijk } \\
\text { orgaan }\end{array}$ & 1991 * & 1997 & 2001 \\
\hline OVD & 1.173 & 1.237 & 1.618 \\
\hline ECABO & 846 & 563 & 560 \\
\hline SLW & 620 & 448 & 612 \\
\hline SOM & 2.290 & 1.705 & 2.100 \\
\hline SVB & 1.807 & 1.072 & 1.319 \\
\hline SVS & 888 & 484 & 579 \\
\hline INNOVAM & 2.194 & 1.306 & 1.764 \\
\hline VBOB & 241 & 167 & 221 \\
\hline VEV & 1.450 & 1.219 & 1.325 \\
\hline SVGB & 111 & 168 & 227 \\
\hline GOC & 986 & 607 & 701 \\
\hline VOC (conf) & 200 & 159 & 189 \\
\hline SVH & 1.467 & 998 & 1.207 \\
\hline VAS & 30 & 14 & 15 \\
\hline VAPRO & 534 & 518 & 727 \\
\hline OVDB & 1.824 & 1.294 & 1.533 \\
\hline SBW & 398 & 291 & 342 \\
\hline VOC (car) & 354 & 316 & 423 \\
\hline BETEX & 58 & 93 & 117 \\
\hline SH\&M & 484 & 329 & 391 \\
\hline SVEB & 519 & 246 & 283 \\
\hline SVK & 1.851 & 1.532 & 1.834 \\
\hline SVO & 831 & 583 & 727 \\
\hline SOI & 1.104 & 679 & 829 \\
\hline Totaal & 22.260 & 16.027 & 19.643 \\
\hline
\end{tabular}

Bron: ROA

Uit de tabel blijkt dat de totale gediplomeerde uitstroom van de primaire opleidingen in 1997 naar verwachting $28 \%$ lager ligt dan de totale uitstroom in 1991. Slechts voor een drietal organen wordt een toename van de uitstroom verwacht: de BETEX $(+60 \%)$, de SVGB $(+51 \%)$ en de OVD $(+5 \%)$. Naar verwachting is de daling van de gediplomeerde uitstroom vooral groot bij de SVEB $(-53 \%)$, de SVS $(-45 \%)$, de SVB $(-41 \%)$ en de INNOVAM $(-40 \%)$.

Voor de periode 1997-2001 wordt weer een duidelijk herstel verwacht van de gediplomeerde uitstroom van de primaire opleidingen ${ }^{16}$. Desalniettemin ligt de totale uitstroom in 2001 naar verwachting nog circa $12 \%$ lager dan de gediplomeerde uitstroom in 1991: een daling van de

16. Uit de jaarcijfers van tabel F.1. is op te maken dat het dieptepunt in de ontwikkeling van de gediplomeerde uitstroom in het jaar 1996 wordt verwacht. 
gediplomeerde uitstroom met ruim 2.500 .

Het herstel van de gediplomeerde uitstroom doet zich voor over de gehele linie, met uitzondering van de ECABO, waar de uitstroom op het niveau van 1997 blijft liggen. De toename van de uitstroom is vooral groot bij de VAPRO $(+40 \%)$, waardoor de gediplomeerde uitstroom bij dit orgaan in 2001 naar verwachting weer aanmerkelijk groter zal zijn dan in het jaar 1991 . Ook bij de SLW $(+37 \%)$, de INNOVAM $(+35 \%)$ en de VBOB $(+32 \%)$ is er sprake van een aanzienlijke toename van de uitstroom in de periode 1997-2001. Bij deze organen is er sprake van een duidelijk herstel na de sterke daling van de uitstroom in de eerste helft van de jaren negentig. Voor de SVGB wordt een $\min$ of meer even grote toename van de gediplomeerde uitstroom verwacht $(+35 \%)$, waardoor de uitstroom bij dit nog relatief kleine landelijke orgaan in het jaar 2001 meer dan het dubbele bedraagt van de uitstroom in 1991.

Een vergelijking van de verwachte ontwikkeling van de gediplomeerde uitstroom in de periode 1997-2001 met de leerlingeninstroom in dezelfde periode lijkt een tegenstrijdig beeld op te leveren. Bij de uitstroom wordt een stijging verwacht van gemiddeld $23 \%$, terwijl de instroom naar verwachting gemiddeld met $10 \%$ daalt. Dit tegenstrijdige beeld is het gevolg van het cyclische karakter van de ontwikkeling van het leerlingwezen, waardoor (vanwege de tijdsvertraging tussen de in- en uitstroom) de verwachte daling van de leerlingenuitstroom aan het eind van de jaren negentig nog niet tot uiting komt in de ontwikkeling van de gediplomeerde uitstroom. Wat dit betreft kan het herstel van de gediplomeerde uitstroom in de periode 19972001 slechts als een tijdelijke opleving worden gezien. 


\section{ENKELE ALTERNATIEVE SCENARIO'S}

\subsection{Inleiding}

In aanvulling op het in de beide voorgaande hoofdstukken beschreven basisscenario van de te verwachten in- en uitstroom van leerlingen in het leerlingwezen, zal in dit hoofdstuk worden ingegaan op een viertal alternatieve scenario's ten aanzien van de toekomstige ontwikkelingen in het leerlingwezen, verbijzonderd naar landelijk orgaan. Deze alternatieve scenario's geven een indruk van de beleidsdoelen die gesteld moeten worden, wanneer getracht wordt langs een bepaalde weg de volgens het basisscenario te verwachten leerlingen- of uitstroomtekorten te voorkomen.

De alternatieve scenario's sluiten enerzijds nauw aan bij de bestaande aandachtspunten in het onderwijsbeleid ten aanzien van het leerlingwezen. Anderzijds brengen ze voor de verschillende landelijke organen in beeld welke mogelijkheden men in principe heeft om langs een bepaalde weg de te verwachten leerlingentekorten te bestrijden. Achtereenvolgens zal daarbij worden ingegaan op de vereiste beleidsdoelstellingen op de volgende vier terreinen:

- het verhogen van de instroom van vrouwen;

- het verhogen van de instroom van ongediplomeerde schoolverlaters;

- het verhogen van de leerlingeninstroom door het dualiseren van het Kort Middelbaar Beroepsonderwijs (KMBO);

- het verhogen van het interne rendement van de primaire opleidingen.

Alle vier beleidsscenario's sluiten nauw aan op de beleidsvisie van het Ministerie van Onderwijs en Wetenschappen met betrekking tot de beroeps- en volwasseneneducatie i.c. het leerlingwezen $^{17}$.

De hier gekozen aanpak betekent dat de geformuleerde alternatieve scenario's niet zijn opgesteld met als doel de gevolgen van een bepaalde beleidsdoelstelling voor de vraag-aanbod verhoudingen in het leerlingwezen in kaart te brengen. In plaats daarvan wordt telkens per landelijk orgaan nagegaan welke concrete beleidsdoelstelling op het desbetreffende punt geformuleerd zou moeten worden om het verwachte tekortschietende aanbod van leerlingen te voorkomen, voor zover dit maximaal mogelijk is. Met andere woorden: de scenario's brengen in kaart wat onder bepaalde realistische randvoorwaarden maximaal bereikt zou kunnen worden, wanneer getracht wordt langs een bepaalde weg de verwachte leerlingentekorten te voorkomen. Men zou dit ook kunnen beschouwen als de marktconforme beleidsdoelstellingen die maximaal realiseerbaar moeten kunnen zijn op basis van de impulsen die van de markt zouden kunnen uitgaan om het evenwicht tussen vraag en aanbod te herstellen. Daarbij wordt echter wel telkens slechts een partiële benadering gevolgd door aan te geven in hoeverre het volgens het basisscenario verwachte tekort louter door het realiseren van én bepaalde beleidsdoelstelling zou kunnen worden bestreden. Praktisch gesproken zal het doorgaans een

17. Vanwege het ontbreken van adequate gegevens was het helaas niet mogelijk een scenario door te rekenen met betrekking tot het verhogen van de instroom van allochtone leerlingen. 
combinatie van maatregelen betreffen. De gehanteerde partiële benaderingen kunnen dan ook in beginsel met elkaar worden gecombineerd.

In deze studie zal niet nader worden ingegaan op de (effectiviteit van) concrete beleidsinstrumenten waarmee getracht zou kunnen worden de in de verschillende scenario's in kaart gebrachte maximaal haalbare beleidsdoelstellingen te realiseren. Wel wordt, zoals gezegd, door de alternatieve scenario's een palet geschetst van de maximale verwachtingen die men onder enigszins realistische randvoorwaarden zou mogen hebben, wanneer langs bepaalde wegen getracht wordt om een tekortschietend aanbod van leerlingen voor de primaire opleidingen in de toekomst te voorkomen.

In de volgende paragrafen van dit hoofdstuk zal voor de verschillende beleidsscenario's telkens worden aangegeven in hoeverre het in principe mogelijk moet zijn om het verwachte tekort langs de desbetreffende weg te voorkomen en wat dit betekent voor de mate waarin leerlingen uit een bepaalde doelgroep voor het leerlingwezen gerecruteerd moeten worden of het interne rendement van de primaire opleidingen moet toenemen. Daarbij zullen telkens de resultaten voor de jaren 1997 en 2001 worden gepresenteerd.

Tabel 2.11. gaf aan dat op grond van het basisscenario, zowel voor het jaar 1997 als voor het jaar 2001, bij 4 van de 24 geanalyseerde landelijke organen (vrijwel) geen tekortschietend aanbod van leerlingen wordt verwacht. Zo wordt er in 1997 niet of nauwelijks een aanbodtekort verwacht bij de INNOVAM, de SVGB, de VOC (confectie) en de SVK. Bij de SGVB, de VOC (confectie) en de SVK worden ook voor 2001 geen leerlingentekorten verwacht. Ook bij de OVDB worden voor dat jaar geen tekorten verwacht. Daarentegen worden er voor de gehele prognoseperiode verhoudingsgewijs grote tekorten verwacht voor de SLW, de VAS, de BETEX, de SVEB, de SVB, de ECABO en de SBW.

\subsection{Instroom vrouwen}

Het is opvallend dat de landelijke organen waarvoor de grootste leerlingentekorten worden verwacht vrijwel allemaal voor het overgrote deel mannelijke leerlingen hebben (zie tabel 2.4.). Uitzondering zijn wat dit betreft de ECABO (38\% mannen) en de VAS ( $27 \%$ mannen). In principe zou het recruteren van meer vrouwelijke leerlingen juist bij organen met veel mannelijke leerlingen een goede mogelijkheid moeten kunnen bieden om de te verwachte leerlingentekorten te bestrijden. Het is echter weinig realistisch te veronderstellen dat dit zonder meer gerealiseerd zou kunnen worden. Temeer daar, zoals uit tabel 2.4 . bleek, het percentage vrouwen bij de meeste organen aan het eind van de jaren tachtig in het geheel niet is toegenomen, terwijl er toch sprake was van een krappe markt.

Om het alternatieve scenario enigszins realistisch te doen zijn, wordt als maximaal haalbare beleidsdoelstelling verondersteld dat van de vrouwen met een bepaalde vooropleiding hetzelfde percentage een primaire opleiding bij een bepaald landelijk orgaan gaat volgen als bij de mannen met de desbetreffende vooropleiding het geval is. Dit betekent dat als bijvoorbeeld $5 \%$ van de 
mannelijke LTO-schoolverlaters een primaire opleiding bij een bepaald landelijk orgaan gaat volgen, in principe ook maximaal $5 \%$ van de vrouwelijke schoolverlaters van het LTO voor deze opleiding zou kunnen kiezen. Het geschetste scenario laat op deze wijze zien in hoeverre meer vrouwelijke leerlingen gerecruteerd zouden kunnen worden, uitgaande van het potentiële aanbod van vrouwen bij de vooropleidingen waaruit een landelijk orgaan tot op heden recruteert. Het aantrekken van meer vrouwelijke leerlingen betekent dan niet de leerlingeninstroom een ander opleidingsprofiel heeft dan momenteel het geval is. Er zouden daarenboven alleen meer vrouwelijke leerlingen kunnen worden aangetrokken, als de uitstroom van vrouwen uit de traditionele vooropleidingen in het algemeen zou toenemen, of wanneer er leerlingen met andere vooropleidingen worden gerecruteerd dan momenteel het geval is. De gekozen aanpak impliceert wel dat voor de landelijke organen met veel vrouwelijke leerlingen de mogelijkheid van het aantrekken van nog meer vrouwen in dit scenario niet wordt uitgewerkt. Overigens kan een dergelijke verdergaande sexe-segregatie ook moeilijk als een emancipatoire doelstelling worden gezien.

Tabel 4.1. laat zien dat in 1997 het aantrekken van meer vrouwen voor 13 van de 20 organen waarvoor een leerlingentekort wordt verwacht mogelijk soelaas zou kunnen bieden. In 2001 is dit slechts bij 4 van de 20 organen het geval: de INNOVAM, de VBOB, de GOC en de VOC (carrosserie). Voor het leerlingwezen in totaal betekent dit dat vrouwen in 1997 gemiddeld $44 \%$ van de leerlingeninstroom moeten uitmaken om de verwachte tekorten, voor zover dit langs deze weg mogelijk is, te doen verdwijnen. Dit vereist een toename van het aandeel van de vrouwelijke leerlingen van maar liefst 18\%-punt ten opzichte van 1989-'91. In het jaar 2001 is hiervoor een instroomaandeel van vrouwelijke leerlingen van $46 \%$ vereist.

Van de organen waarvoor in het basisscenario verhoudingsgewijs grote tekorten worden verwacht, is het recruteren van meer vrouwen op de middellange termijn (1997) echter alleen toereikend voor de SBW en de ECABO. Opvallend genoeg heeft de ECABO overigens momenteel reeds meer vrouwelijke dan mannelijke leerlingen. Daarentegen oogt de SBW met 99\% mannelijke leerlingen tot op heden welhaast als een onneembaar mannenbolwerk. Op de langere termijn (2001) blijkt het recruteren van meer vrouwen, gegeven de vooropleidingen van waaruit leerlingen worden aangetrokken, voor geen van de organen met relatief grote leerlingentekorten voldoende soelaas te bieden om de te verwachten tekorten geheel te kunnen voorkomen.

Desalniettemin biedt het aantrekken van meer vrouwelijke leerlingen voor verschillende landelijke organen met een relatief hoog leerlingentekort wel degelijk mogelijkheden om het verwachte leerlingentekort (aanzienlijk) te verminderen. Naast de ECABO en de SBW geldt dit met name voor de SVB, de BETEX en de SVEB. 
Tabel 4.1. Vereiste percentage vrouwelijke leerlingen om een vraag-aanbod evenwicht te bewerkstelligen*, 1997 en 2001

\begin{tabular}{|c|c|c|c|c|c|c|c|}
\hline \multirow[b]{2}{*}{$\begin{array}{l}\text { Landelijk } \\
\text { orgaan }\end{array}$} & \multicolumn{2}{|l|}{ 1989-'91 } & \multicolumn{2}{|l|}{1997} & \multicolumn{3}{|c|}{2001} \\
\hline & $\begin{array}{l}\text { Percentage } \\
\text { vrouwen }\end{array}$ & $\begin{array}{l}\text { e Verwacht } \\
\text { aanbod- } \\
\text { tekort }\end{array}$ & $\begin{array}{l}\text { Vereist c.q. } \\
\text { maximaal } \\
\text { haalbaar } \\
\text { percentage } \\
\text { vrouwen }\end{array}$ & $\begin{array}{l}\text { Blijvend } \\
\text { tekort }\end{array}$ & $\begin{array}{l}\text { Verwacht } \\
\text { aanbod- } \\
\text { tekort }\end{array}$ & $\begin{array}{l}\text { Vereist c.q. } \\
\text { maximaal } \\
\text { haalbaar } \\
\text { percentage } \\
\text { vrouwen }\end{array}$ & $\begin{array}{l}\text { Blijvend } \\
\text { tekort }\end{array}$ \\
\hline OVD & 67 & 1.608 & 71 & 1052 & 1.149 & 69 & 840 \\
\hline ECABO & 57 & 746 & 71 & & 948 & 73 & 215 \\
\hline SLW & 3 & 2.589 & 26 & 2315 & 2.738 & 25 & 2.516 \\
\hline SOM & 3 & 1.141 & 27 & & 1.787 & 33 & 502 \\
\hline SVB & 1 & 1.389 & 32 & 189 & 1.833 & 34 & 757 \\
\hline SVS & 3 & 402 & 29 & & 587 & 34 & 167 \\
\hline INNOVAM & 1 & - & - & & 293 & 12 & \\
\hline VBOB & 21 & 78 & 35 & & 85 & 36 & \\
\hline VEV & 2 & 1.386 & 29 & & 2.269 & 37 & 730 \\
\hline SVGB & 38 & - & - & & - & - & \\
\hline GOC & 23 & 439 & 46 & & 583 & 53 & \\
\hline VOC (conf) & 92 & 2 & 92 & 2 & - & - & \\
\hline SVH & 27 & 675 & 43 & & 881 & 44 & 226 \\
\hline VAS & 54 & 69 & 59 & 65 & 71 & 57 & 69 \\
\hline VAPRO & 2 & 146 & 12 & & 298 & 21 & 32 \\
\hline OVDB & 96 & 38 & 96 & & - & - & \\
\hline SBW & 1 & 371 & 34 & & 553 & 31 & 311 \\
\hline VOC (car) & 1 & 163 & 17 & & 200 & 20 & \\
\hline BETEX & 9 & 300 & 55 & 104 & 295 & 55 & 98 \\
\hline SH\&M & 6 & 365 & 29 & 94 & 529 & 29 & 311 \\
\hline SVEB & 5 & 303 & 36 & 76 & 417 & 32 & 280 \\
\hline SVK & 93 & & - & & - & - & \\
\hline svo & 39 & 337 & 53 & & 363 & 53 & 32 \\
\hline sOI & 1 & 705 & 30 & & 958 & 39 & 74 \\
\hline Totaal & 26 & 12.411 & 44 & 3.896 & 15.833 & 46 & 7.160 \\
\hline
\end{tabular}

* Uitgangspunt daarbij is dat vrouwen hun achterstand in participatie in het leerlingwezen ten opzichte van mannen inhalen.

Bron: ROA

\subsection{Instroom voortijdig schoolverlaters}

In de beleidsnotitie 'Een goed voorbereidende start' (Ministerie van Onderwijs en Wetenschappen, 1993) wordt het leerlingwezen een cruciale rol toebedeeld in het kader van het beleid gericht op het terugdringen van het aantal schoolverlaters dat het initieel onderwijs zonder een startkwalificatie als beginnend beroepsbeoefenaar verlaat. ledereen die zonder een dergelijke minimale startkwalificatie op het niveau primair leerlingwezen/kort middelbaar beroepsonderwijs het initieel onderwijs verlaat wordt daarbij als een voortijdig schoolverlater gezien, inclusief de MAVO- en LBO-gediplomeerden. Vanuit dit oogpunt kan bijna per definitie 
vrijwel de gehele leerlingeninstroom van het leerlingwezen als doelgroep worden beschouwd voor een scenario gericht op het vergroten van de instroom van voortijdig schoolverlaters. In dit beleidsscenario zal echter een toespitsing van de doelgroep plaatsvinden, door uit te gaan van de 'harde kern' van de voortijdig schoolverlaters, dat wil zeggen: de scholieren die zonder een LBO- of MAVO-diploma het initiële dagonderwijs verlaten.

Om een zo reeël mogelijk beeld te krijgen van de mogelijkheden die de verschillende landelijke organen hebben om meer ongediplomeerden aan te trekken, wordt verondersteld dat wanneer er meer leerlingen met een bepaalde opleidingsachtergrond in het leerlingwezen instromen, deze verhoogde instroom zich op dezelfde wijze over de verschillende landelijke organen verspreidt als de reeds bestaande instroom met de desbetreffende opleidingsachtergrond. Dit betekent dat verondersteld wordt dat het verhogen van de instroom van voortijdig schoolverlaters het meeste soelaas biedt aan landelijke organen (1) die reeds (een bepaalde groep) ongediplomeerde leerlingen aantrekken, (2) waarvan het potentiële additionele aanbod nog groot is.

Uit tabel 2.3. kan worden afgeleid dat bij een aantal organen in 1991 meer dan $10 \%$ van de leerlingeninstroom in de primaire opleidingen betrekking heeft op deze ongediplomeerde schoolverlaters. Dit is het geval bij de SVK, de OVD, de SVB, de OVDB, de SVM, de VEV, de ECABO en de SOI.

Tabel 4.2. laat zien dat in 1997 voor 10 van de 20 landelijke organen waarvoor in het basisscenario een leerlingentekort wordt verwacht, dit tekort in principe zou kunnen worden voorkomen door het vergroten van de ongediplomeerde instroom. In het jaar 2001 is dit nog slechts bij 6 van de 20 organen het geval: de OVD, de INNOVAM, de VBOB, de SVM, de VOC (carrosserie) en de SVO. Daarbij moet echter de kanttekening worden gemaakt dat dit bij enkele organen betekent dat vrijwel de gehele potentiële doelgroep voor een opleiding in het leerlingwezen zou moeten gaan kiezen. Ook bij de andere organen is doorgaans een zeer forse toename van de ongediplomeerde instroom in het leerlingwezen vereist.

Voor geen van de eerder genoemde organen waarvoor volgens het basisscenario verhoudingsgewijs grote tekorten worden verwacht, is het vergroten van de instroom van ongediplomeerden toereikend om de verwachte tekorten geheel te voorkomen. Met name voor de ECABO, de SVB, de SBW, de BETEX en de SVEB biedt het vergroten van de ongediplomeerde instroom echter wel degelijk mogelijkheden om het toekomstige leerlingentekort enigszins te verminderen. Overigens zullen daarbij, naast de ongediplomeerde LBO- en MAVO-schoolverlaters, vooral ook ongediplomeerde HAVO- en VWO-ers moeten worden aangetrokken. 
Tabel 4.2. Percentage ongediplomeerden dat voor leerlingwezen moet kiezen om vraag-aanbod evenwicht te bewerkstelligen, 1997 en 2001

\begin{tabular}{|c|c|c|c|c|c|c|c|}
\hline \multirow[b]{2}{*}{$\begin{array}{l}\text { Landelijk } \\
\text { orgaan }\end{array}$} & \multicolumn{3}{|c|}{1997} & \multicolumn{4}{|c|}{2001} \\
\hline & $\begin{array}{l}\text { Verwacht } \\
\text { aanbod- } \\
\text { tekort }\end{array}$ & $\begin{array}{l}\text { Vereist } \\
\text { percentage } \\
\text { ongediplo- } \\
\text { meerden }\end{array}$ & $\begin{array}{l}\text { Blijvend } \\
\text { tekort }\end{array}$ & $\begin{array}{l}\text { Verwacht } \\
\text { aanbod- } \\
\text { tekort }\end{array}$ & $\begin{array}{l}\text { Vereist } \\
\text { percenta } \\
\text { ongedipl } \\
\text { meerder }\end{array}$ & $\begin{array}{l}\text { tage } \\
\text { olo- } \\
\text { n }\end{array}$ & $\begin{array}{l}\text { Blijvend } \\
\text { tekort }\end{array}$ \\
\hline OVD & 1.608 & 90 & & 1.149 & 60 & & \\
\hline ECABO & 746 & 99 & & 948 & 100 & * & 407 \\
\hline SLW & 2.589 & $100 *$ & 2.540 & 2.738 & 100 & * & 2.695 \\
\hline SOM & 1.141 & $100 *$ & 594 & 1.787 & 100 & $*$ & 1.309 \\
\hline SVB & 1.389 & $100 *$ & 662 & 1.833 & 100 & * & 1.176 \\
\hline SVS & 402 & 72 & & 587 & 100 & * & 121 \\
\hline INNOVAM & - & - & & 293 & 56 & & \\
\hline VBOB & 78 & 48 & & 85 & 56 & & \\
\hline VEV & 1.386 & $100 *$ & 747 & 2.269 & 100 & * & 1.745 \\
\hline SVGB & - & - & & - & - & & \\
\hline GOC & 439 & 96 & & 583 & 100 & * & 160 \\
\hline VOC (conf) & 2 & 1 & & - & - & & \\
\hline SVH & 675 & 65 & & 881 & 87 & & \\
\hline VAS & 69 & $100 *$ & 52 & 71 & 100 & * & 56 \\
\hline VAPRO & 146 & 88 & & 298 & 100 & $*$ & 143 \\
\hline OVDB & 38 & 6 & & - & - & & \\
\hline SBW & 371 & $100 *$ & 190 & 553 & 100 & $*$ & 428 \\
\hline VOC (car) & 163 & 54 & & 200 & 67 & & \\
\hline BETEX & 300 & $100 *$ & 162 & 295 & 100 & * & 153 \\
\hline SH\&M & 365 & $100 *$ & 156 & 529 & 100 & * & 355 \\
\hline SVEB & 303 & $100 *$ & 217 & 417 & 100 & $*$ & 350 \\
\hline SVK & - & - & & - & - & & \\
\hline svo & 337 & 76 & & 363 & 90 & & \\
\hline SOI & 705 & $100 *$ & 144 & 958 & 100 & $*$ & 471 \\
\hline
\end{tabular}

* Theoretisch maximum percentage Bron: ROA

\subsection{Dualisering KMBO}

Een derde mogelijkheid om de instroom van het leerlingwezen te vergroten is het dualiseren van de KMBO-opleidingen. Een dergelijke dualisering sluit ook aan bij de wens de aansluiting tussen onderwijs en bedrijfsleven te verbeteren door het vergroten van het belang van het duale onderwijs. In feite gaat het hier echter louter om het verleggen van het leerlingenaanbod van het KMBO naar het leerlingwezen. Dit betekent dat het uiteindelijke aanbod van gekwalificeerde arbeidskrachten, als gevolg van de inkrimping van het $\mathrm{KMBO}$, in feite niet toeneemt.

Om een zo reeël mogelijke indruk te krijgen van de mate waarin dit beleidsscenario de verwachte leerlingstekorten in het leerlingwezen zou kunnen voorkomen, wordt verondersteld 
$-60-$

dat een landelijk orgaan alleen kan putten uit het reservoir van het min of meer overeenkomstige opleidingstraject in het KMBO. Dit betekent dat dit alternatieve scenario geen betekenis heeft voor de organen waarvoor een parallel opleidingstraject binnen het KMBO ontbreekt. Dit is het geval bij de SLW, de VAS, de SBW, de VOC (carrosserie), de BETEX en de SVO. Bij de VBOB en de SVEB doet zich het probleem voor dat beide organen aan dezelfde KMBO-opleiding gerelateerd zijn, waardoor zij onderling zullen moeten concurreren om dezelfde potentiële additionele leerlingeninstroom.

Tabel 4.3. Vereiste percentage van de parallelle KMBO-opleidingen dat gedualiseerd moet worden om vraag-aanbod evenwicht te bewerkstelligen, 1997 en 2001

\begin{tabular}{|c|c|c|c|c|c|c|c|}
\hline \multirow[b]{2}{*}{$\begin{array}{l}\text { Landelijk } \\
\text { orgaan }\end{array}$} & \multirow[b]{2}{*}{$\begin{array}{l}\text { Verwacht } \\
\text { aanbod- } \\
\text { tekort }\end{array}$} & \multicolumn{3}{|l|}{1997} & \multirow[b]{2}{*}{$\begin{array}{l}\text { Verwacht } \\
\text { aanbod- } \\
\text { tekort }\end{array}$} & \multicolumn{2}{|l|}{2001} \\
\hline & & $\begin{array}{c}\text { Vereiste } \\
\text { dualiserin } \\
\text { KMBO } \\
\%\end{array}$ & & $\begin{array}{l}\text { Blijvend } \\
\text { tekort }\end{array}$ & & $\begin{array}{c}\text { Vereiste } \\
\text { dualisering } \\
\text { KMBO } \\
\%\end{array}$ & $\begin{array}{l}\text { Blijvend } \\
\text { tekort }\end{array}$ \\
\hline OVD & 1.608 & 58 & & & 1.149 & 45 & \\
\hline ECABO & 746 & 13 & & & 948 & 19 & \\
\hline SLW & 2.589 & & & & 2.738 & & \\
\hline SOM & 1.141 & 100 & * & 46 & 1.787 & $100 *$ & 780 \\
\hline SVB & 1.389 & 100 & * & 1.363 & 1.833 & $100 *$ & 1.808 \\
\hline SVS & 402 & 100 & * & 344 & 587 & $100 *$ & 534 \\
\hline INNOVAM & - & - & & & 293 & 34 & \\
\hline VBOB & 78 & 47 & & & 85 & 55 & \\
\hline VEV & 1.386 & 83 & & & 2.269 & $100 *$ & 726 \\
\hline SVGB & - & & & & - & & \\
\hline GOC & 439 & 100 & * & 214 & 583 & $100 *$ & 376 \\
\hline VOC (conf) & 2 & & & & - & & \\
\hline SVH & 675 & 72 & & & 881 & $100 *$ & 15 \\
\hline VAS & 69 & & & & 71 & & \\
\hline VAPRO & 146 & 28 & & & 298 & 63 & \\
\hline OVDB & 38 & 2 & & & - & - & \\
\hline SBW & 371 & & & & 553 & & \\
\hline VOC (car) & 163 & & & & 200 & & \\
\hline BETEX & 300 & & & & 295 & & \\
\hline SH\&M & 365 & 67 & & & 529 & $100 *$ & 25 \\
\hline SVEB & 303 & 100 & $*$ & 136 & 417 & $100 *$ & 263 \\
\hline SVK & - & - & & & - & - & \\
\hline svo & 337 & & & & 363 & & \\
\hline sol & 705 & 100 & * & 359 & 958 & $100 *$ & 640 \\
\hline bakkers (VBOB + SVEB) & 381 & 100 & * & 214 & 502 & $100 *$ & 348 \\
\hline
\end{tabular}

* Theoretisch maximum percentage

Bron: ROA

Uit tabel 4.3. blijkt dat het dualiseren van de parallelle KMBO-opleidingen voor 8 van de 20 landelijke organen waarvoor in 1997 een leerlingentekort wordt verwacht mogelijkheden biedt 
om een toekomstig leerlingentekort te voorkomen. In het jaar 2001 is dit nog slechts bij 5 van de 20 organen het geval: de OVD, de ECABO, de INNOVAM, de VBOB en de VAPRO. Voor de landelijke organen waarvoor de grootste leerlingentekorten worden verwacht, biedt dualisering van het KMBO alleen bij de ECABO de mogelijkheid om een toekomstig leerlingentekort te voorkomen. Bij de SVB is er daarentegen slechts sprake van een minimale reductie van het verwachte tekort vanwege de zeer geringe omvang van het parallelle opleidingstraject in het KMBO. Bij de SVEB zou dit beleidsscenario ook tot een geringer toekomstig leerlingentekort kunnen leiden, al moet daarbij, zoals reeds werd opgemerkt, worden bedacht dat dit landelijke orgaan met de $\mathrm{VBOB}$ in concurrentie is om dezelfde potentiële leerlingeninstroom. Voor de andere landelijke organen waarvoor een relatief groot leerlingentekort wordt verwacht (de SLW, de VAS, de BETEX en de SBW) biedt dit alternatieve scenario geen enkel soelaas, vanwege het ontbreken van een min of meer overeenkomstig opleidingstraject binnen het KMBO.

\subsection{Verhoging interne rendement}

Het vierde alternatieve scenario voor de ontwikkelingen in het leerlingwezen heeft betrekking op de mogelijkheden om de vraag-aanbod verhoudingen in het leerlingwezen in evenwicht te brengen door een verhoging van het interne rendement van de primaire opleidingen te bewerkstelligen. Dit temeer daar het huidige rendement laag is. Strikt genomen leidt een rendementsverhoging vanzelfsprekend niet tot een verhoging van de leerlingeninstroom, maar tot een vergroting van de uitstroom van gediplomeerde leerlingen, gegeven een bepaalde instroom. Het scenario heeft derhalve niet direct betrekking op de mate waarin de leerlingeninstroom tekort schiet ten opzichte van de instroombehoefte van de verschillende landelijke organen. Aangenomen mag echter worden dat de vraag naar leerlingen in feite een afgeleide is van de behoefte aan nieuwe vakmensen. Met andere woorden: ook een toename van het interne rendement van de primaire opleidingen biedt in principe de mogelijkheid om de volgens het basisscenario verwachte aanbodtekorten in het leerlingwezen te voorkomen.

Tabel 4.4. laat zien dat bij maar liefst 16 van de 20 landelijke organen waarvoor in 1997 een tekortschietend aanbod wordt verwacht, een verhoging van het interne rendement de volgens het basisscenario verwachte tekorten theoretisch gezien zou kunnen voorkomen. In het jaar 2001 is dit bij nog 15 landelijke organen het geval ${ }^{18}$ (zie tabel 4.5.). Voor enkele organen zou dit echter betekenen dat het interne rendement onwaarschijnlijk hoog zou moeten komen te liggen. Voor het leerlingwezen in totaal zou het interne rendement van de primaire opleidingen in 1997 op $70 \%$ dienen te liggen, hetgeen een toename impliceert van 17\%-punt ten opzichte van het rendement in de periode 1986-1991. In 2001 zou het gemiddelde rendement op $80 \%$ moeten liggen om de verwachte tekorten, voor zover dit langs deze weg mogelijk is, te doen verdwijnen.

18. In de tabel is het verwachte tekort ter wille van de vergelijkbaarheid met de andere scenario's uitgedrukt in termen van het tekort aan instromende leerlingen. In feite zou een rendementsverhoging voor deze instroom pas enkele jaren later van invloed zijn op de uitstroom van leerlingen. Voor de conclusies die uit de resultaten van dit alternatieve scenario kunnen worden getrokken is deze kanttekening echter niet van belang. 
Tabel 4.4. Vereiste rendementspercentages leerlingwezen om vraag-aanbod evenwicht te bewerkstelligen, 1997 en 2001

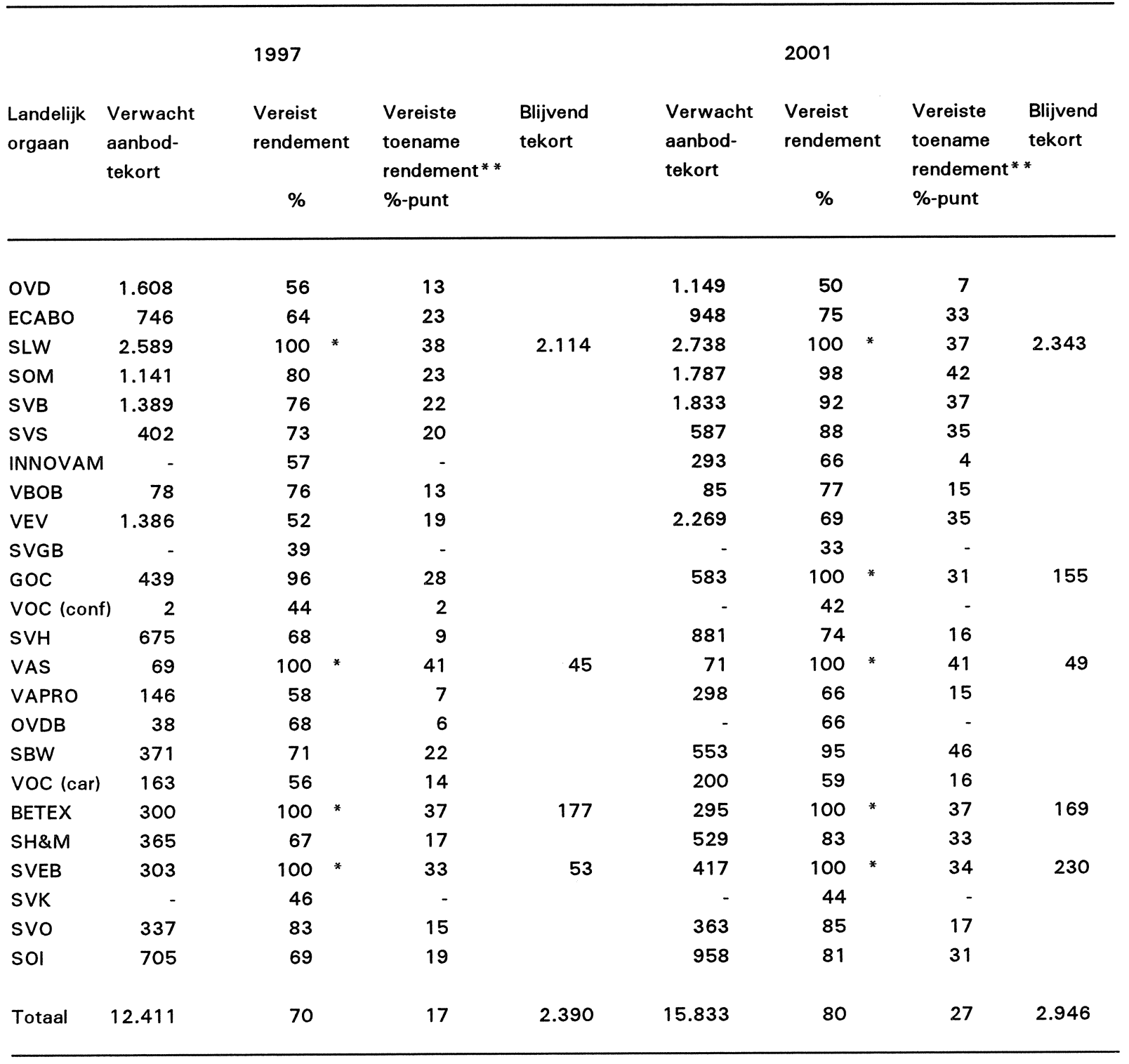

* Theoretisch maximum percentage

* Toename ten opzichte van het rendement in de periode 1986-1991 (zie tabel 3.4.).

Bron: ROA

Van de organen waarvoor volgens het basisscenario verhoudingsgewijs een groot leerlingentekort wordt verwacht, lijkt dit vierde beleidsscenario alleen bij de SBW, de SVB en de ECABO de mogelijkheid te bieden het verwachte tekort voor 1997 te voorkomen. Hiervoor is vereist dat het rendement van de primaire opleidingen van de SBW op $71 \%$ komt te liggen, hetgeen een toename betekent van $22 \%$-punt ten opzichte van het interne rendement in de periode 1986-'91. Bij de SVB kan het aanbodtekort slechts worden voorkomen bij een rendement van $76 \%$, wat een toename van het rendement met $22 \%$-punt zou betekenen. Voor de ECABO is een soortgelijke rendementstoename vereist $(+23 \%)$. Gezien het relatief lage huidige rendement, betekent dit dat het toekomstige rendement bij dit orgaan op $64 \%$ zou moeten komen te liggen. 
Ook voor het jaar 2001 zou het verwachte aanbodtekort bij de SBW, de SVB en de ECABO theoretisch gezien kunnen worden voorkomen door een toename van het interne rendement van de primaire opleidingen. Voor de SBW en de SVB betekent dit echter dat het rendement boven de $90 \%$ zou moeten komen te liggen, hetgeen een weinig realistische optie is. Desalniettemin biedt het verhogen van het interne rendement van de primaire opleidingen ook voor de landelijke organen die naar verwachting geconfronteerd zullen worden met de grootste aanbodtekorten, goede mogelijkheden om de verwachte tekorten aanzienlijk te reduceren. De enige uitzondering is wat dit betreft de SLW, waarvan het verwachte tekort ook bij een substantiële verhoging van het interne rendement nog zeer omvangrijk blijft ${ }^{19}$.

19. Overigens blijft het verwachte tekort, bij een aanzienlijke verhoging van het interne rendement, ook bij de VAS verhoudingsgewijs nog hoog. In absolute aantallen gaat het hier slechts om een gering leerlingentekort. 


\section{BESLUIT}

Zoals in het inleidende hoofdstuk werd uiteengezet, was het centrale aandachtpunt van deze toekomstverkenning voor het leerlingwezen de vraag in hoeverre het aanbod van leerlingen voor de primaire opleidingen van het leerlingwezen in de (nabije) toekomst tekort zou kunnen schieten ten opzichte van de behoefte aan leerlingen in de verschillende bedrijfssectoren. De vrees voor een tekortschietende leerlingeninstroom wordt ingegeven door de verwachte afnemende uitstroom van schoolverlaters uit het initiële dagonderwijs, als gevolg van een 'ontgroening' van de bevolking, waarbij de problematiek voor het leerlingwezen nog versterkt wordt door de afkalvende belangstelling voor het lager beroepsonderwijs dat voor het leerlingwezen nog steeds het belangrijkste toevoerkanaal van leerlingen vormt.

Om ook een antwoord te kunnen geven op de vraag hoe de toekomstige uitstroom van leerlingen uit de primaire opleidingen zich zal ontwikkelen, is tevens getracht om het longitudinale interne rendement van de opleidingen in beeld te brengen.

De toekomstverkenning heeft betrekking op de te verwachten in- en uitstroom van leerlingen in de periode 1993-2001, verbijzonderd naar $24 \mathrm{~min}$ of meer bedrijfstaksgewijs georganiseerde landelijke organen. Uitgangspunt van de toekomstverkenning is een basisscenario waarin getracht is een zo reëel mogelijk beeld te schetsen van de verwachten ontwikkelingen in het aanbod van leerlingen. Dit verwachte aanbod wordt geconfronteerd met de vraag naar leerlingen, zoals deze gekwantificeerd kan worden op basis van de streefcijfers die per landelijke organen jaarlijks worden opgesteld in het kader van de Bijdrageregeling Vakopleiding Leerlingwezen.

In aansluiting op dit basisscenario is een viertal alternatieve scenario's opgesteld waarin een beeld geschetst wordt van de mogelijkheden die er zijn om de voor een bepaald landelijk orgaan verwachte leerlingentekorten te voorkomen. Daarbij wordt achtereenvolgens ingegaan op de vereiste beleidsdoelstellingen met betrekking tot het verhogen van de instroom van vrouwen en voortijdig schoolverlaters, het verhogen van de instroom door het dualiseren van het KMBO en het verhogen van het interne rendement van de primaire opleidingen.

In hoofdstuk 2 wordt eerst een beeld geschetst van de ontwikkeling van de leerlingeninstroom in de primaire opleidingen van het leerlingwezen in het (recente) verleden, verbijzonderd naar de vooropleidingen van de leerlingen. Daaruit blijkt dat gezien de forse daling van de uitstroom uit de traditionele vooropleidingen die zich voordeed in de periode 1978-1990, de vrees voor een toekomstig tekortschietend aanbod van leerlingen in het leerlingwezen bepaald niet ongegrond is. Wat dit betreft is het zelfs al enigszins verbazingwekkend dat men er in de jaren ' 80 in geslaagd is de doelstellingen van de verdubbelingsoperatie van het leerlingwezen te realiseren.

Een zorgwekkend signaal voor de toekomst is wat dit betreft dat in de jaren 1988-1990 de instroom van leerlingen met een LTO-diploma in de primaire opleidingen van het leerlingwezen groter is dan het aantal LTO-gediplomeerden dat in deze jaren de school verlaat. Aangenomen 
mag worden dat men, bij wijze van inhaalslag, slechts een beperkt aantal jaren kan putten uit een stuwmeer van LTO-gediplomeerden die reeds enige jaren geleden het dagonderwijs hebben verlaten. Wanneer het stuwmeer is opgedroogd, zal men voortaan weer zijn aangewezen op de schoolverlaters die in het desbetreffende jaar hun LTO-opleiding hebben afgerond, hetgeen de (potentiële) instroom van LTO-schoolverlaters aanmerkelijk zal beperken. Daarbij moet worden beseft dat het hier nog steeds om verreweg de grootste instroomcategorie gaat.

Wel blijkt dat de meeste landelijke organen er in de jaren tachtig in zijn geslaagd om een steeds groter deel van hun leerlingeninstroom te recruteren uit niet-traditionele vooropleidingen. Een uitzondering is wat dit betreft de VAPRO (procesindustrie).

Ook is nagegaan in hoeverre de landelijke organen er reeds in slagen hun leerlingeninstroom te vergroten door het aantrekken van meer vrouwelijke leerlingen. Op basis van de beschikbare cijfers voor de jaren 1988 en 1991 blijkt dat er in de tussenliggende periode, in tegenstelling tot wat misschien verwacht zou mogen worden, per saldo zelfs sprake is geweest van een daling van het percentage vrouwelijke leerlingen in het primaire leerlingwezen van $31 \%$ naar $29 \%$. In het algemeen is er duidelijk sprake van een tweedeling tussen enerzijds een groot aantal organen dat voor het overgrote deel mannen recruteert en anderzijds enkele organen die met name vrouwelijke leerlingen kennen, zonder dat daarbij noemenswaardige verschuivingen optreden in het aandeel van vrouwen.

Wanneer gekeken wordt naar de leeftijdsopbouw van de instroom in de primaire opleidingen, dan blijkt dat het overgrote deel van de instroom tot de jongste leeftijdscategorie (15-22 jaar) behoort. Slechts bij een tweetal organen, de VAS en de VAPRO, bestaat meer dan de helft van de leerlingeninstroom uit de leeftijdsgroep ouder dan 27 jaar.

Door per landelijk orgaan de jaarlijkse uitstroom van gediplomeerden te relateren aan de instroom van leerlingen in de voorgaande jaren, kan per landelijk orgaan een nauwkeurig beeld worden verkregen van het (longitudinale) interne rendement van de primaire opleidingen. Uit de schattingsresultaten van het uitstroommodel blijkt dat het interne rendement tussen de verschillende organen uiteenloopt van $38 \%$ bij de VEV tot $68 \%$ bij de GOC. Naast de VEV is er ook sprake van zeer lage rendementen bij de OVD $(40 \%)$, de ECABO $(43 \%)$ en de SVGB $(43 \%)$. Een relatief hoog rendement doet zich daarentegen ook voor bij de OVDB (67\%), de SLW (65\%) en de SVEB $(65 \%)$.

Bij een vergelijking van het gemiddelde rendement in de periodes 1980-1985 en 1986-1991, blijkt dat er bij 8 organen sprake is van een significante toename van het interne rendement in de tweede helft van de jaren tachtig, terwijl bij 3 landelijke organen het interne rendement is verslechterd. Al met al is er derhalve de laatste jaren per saldo sprake geweest van een lichte verbetering van het interne rendement van de primaire opleidingen.

Op basis van de genoemde streefcijfers in het kader van de Bijdrageregeling Vakopleidingen Leerlingwezen voor de jaren 1990-1992 is getracht per landelijk orgaan een inschatting te 
maken van de verwachte ontwikkeling van de geplande instroom in het leerlingwezen op de langere termijn. In de meeste gevallen is daarbij gekozen voor een conservatieve aanpak door te verwachten dat de instroombehoefte op het niveau van 1992 blijft liggen.

Op basis van achtereenvolgens een modellering van de totale instroom per vooropleiding, waarbij ook rekening wordt gehouden met het stuwmeereffect, en een eenvoudig verdeelmodel naar landelijk orgaan, zijn prognoses opgesteld van de verwachte instroom in de primaire opleidingen voor de jaren 1993-2001. Deze prognoses kunnen gezien worden als het basisscenario voor de te verwachten ontwikkelingen.

Uit de prognoseresultaten blijkt dat over het geheel genomen de leerlingeninstroom op de middellange termijn (1997) naar verwachting sterk is afgenomen ten opzichte van de instroom in 1991. Daarbij gaat het om een daling van ruim 45.000 leerlingen in 1991 naar nog geen 37.000 leerlingen in 1997 , een daling van maar liefst $18 \%$. Het meest opvallend is de daling van de leerlingeninstroom bij de SBW (-35\%), de SVEB (-34\%), de ECABO (-33\%) en de VEV $(-32 \%)$. Daarentegen wordt voor slechts drie organen een toename van de instroom verwacht: de SVGB $(+35 \%)$, de BETEX $(+7 \%)$ en de OVD $(+2 \%)$

Voor de periode 1997-2001 wordt volgens het basisscenario een verdere daling van de leerlingeninstroom verwacht van bijna $10 \%$. Opnieuw is de daling naar verwachting het grootst bij de SBW $(-25 \%)$, de SVEB $(-25 \%)$ en de VEV $(-24 \%)$. Daarentegen wordt er in deze periode bij 6 landelijke organen een toename van de instroom verwacht. Naast de genoemde organen die ook in de periode 1991-1997 hun instroom zien toenemen, de SVGB $(+17 \%)$, de OVD $(+12 \%)$ en de BETEX $(+3 \%)$, wordt nu ook een geringe toename van de leerlingeninstroom verwacht bij de VOC (confectietechniek, $+6 \%$ ), de SVK $(+4 \%)$ en de OVDB $(+3 \%)$.

Uit de confrontatie van de verwachte instroomontwikkelingen volgens het basisscenario met de verwachte vraag naar nieuwe leerlingen, blijkt dat voor het jaar 1997 in totaal een aanbodtekort wordt verwacht van ruim 12.000 leerlingen. In procenten van de geplande instroom betekent dit een tekort van maar liefst $25 \%$. De grootste tekorten worden verwacht bij de landelijke organen, waarvoor de geplande toename van de instroom het grootst is: de SLW (tekort 74\%), de VAS (tekort $71 \%$ ) en de BETEX (tekort $61 \%)^{20}$. Andere organen waarvoor op grond van het basisscenario een groot leerlingentekort wordt verwacht zijn de SVEB (tekort $35 \%$ ), de ECABO (tekort $34 \%$ ) en de SBW (tekort 34\%). Slechts een viertal landelijke organen zal volgens het basiscenario in 1997 niet of nauwelijks worden geconfronteerd met een tekort schietende leerlingeninstroom: de SVK, de SVGB, de INNOVAM en de OVDB.

Op grond van het basisscenario wordt verwacht dat het totale aanbodtekort op de langere termijn zal uitgroeien tot 16.000 leerlingen in het jaar 2001. In procenten van de geplande instroom is dit een tekort van 32\%. In het algemeen zullen in het jaar 2001 dezelfde organen

20. Men kan zich in dit verband natuurlijk afvragen in hoeverre de geplande instroom als realistisch kan worden beschouwd. 
verhoudingsgewijs grote tekorten ondervinden als voor 1997 werd verwacht. Daarbij wordt vooral een sterke toename van het tekort verwacht bij de VEV (van $28 \%$ naar $45 \%$ ), de SBW (van $34 \%$ naar $50 \%$ ) en de SVEB (van $40 \%$ naar $55 \%$ ). Bij de INNOVAM slaat het verwachte overschot voor 1997 om in een tekort voor 2001.

Ten aanzien van de gediplomeerde uitstroom van de primaire opleidingen wordt op grond van het basisscenario voor 1997 een daling van $28 \%$ verwacht ten opzichte van de totale uitstroom in 1991. Alleen voor de BETEX $(+60 \%)$, de SVGB $(+51 \%)$ en de OVD $(+5 \%)$ wordt een toename van de gediplomeerde uitstroom verwacht. Daarentegen is naar verwachting de daling van de gediplomeerde uitstroom tussen 1991 en 1997 vooral groot bij de SVEB (-53\%), de SVS $(-45 \%)$, de SVB $(-41 \%)$ en de INNOVAM $(-40 \%)$.

In de periode 1997-2001 wordt echter een duidelijk herstel verwacht van de gediplomeerde uitstroom van de primaire opleidingen. Desalniettemin ligt de totale uitstroom in het jaar 2001 naar verwachting nog circa $12 \%$ onder het niveau van 1991 . Het herstel van de gediplomeerde uitstroom doet zich voor over de gehele linie, met uitzondering van de ECABO, waar de uitstroom op het niveau van 1997 blijft liggen. De toename van de gediplomeerde uitstroom is naar verwachting vooral groot bij de VAPRO (+40\%), de SLW $(+37 \%)$, de INNOVAM $(+35 \%)$, de SVGB $(+35 \%)$ en de VBOB $(+32 \%)$

Op basis van vier alternatieve scenario's is tenslotte nagegaan in hoeverre de op grond van het basisscenario verwachte leerlingentekorten voorkomen zouden kunnen worden. Daarbij is telkens gekeken naar de beleidsdoelstellingen die in principe realiseerbaar zouden kunnen zijn op basis van de impulsen die van de markt zouden kunnen uitgaan om het verstoorde evenwicht tussen vraag en aanbod te herstellen. Men zou dit kunnen beschouwen als de maximaal haalbare marktconforme beleidsdoelstelling op een bepaald terrein.

De prognoseresultaten van het beleidsscenario gericht op het verhogen van de instroom van meer vrouwelijke leerlingen laten zien dat het aantrekken van meer vrouwen in 1997 voor 13 van de 20 landelijke organen die met leerlingentekorten worden geconfronteerd het mogelijk moet maken om deze tekorten te voorkomen. In 2001 is dit nog slechts bij 4 van de 20 organen het geval. Van de organen waarvoor op grond van het basisscenario relatief grote tekorten worden verwacht, is het aantrekken van meer vrouwen op de middellange termijn echter alleen toereikend voor de SBW en de ECABO. Op de langere termijn is het verhogen van de instroom van vrouwen echter voor geen van deze organen toereikend om de verwachte tekorten geheel te kunnen voorkomen. Desalniettemin biedt het aantrekken van meer vrouwelijke leerlingen voor verschillende landelijke organen met een relatief hoog leerlingentekort goede mogelijkheden om het verwachte tekort aanzienlijk te verminderen. Naast de ECABO en de SBW geldt dit met name voor de SVB, de BETEX en de SVEB. Om dit te kunnen realiseren is doorgaans een aanzienlijke beleidsinspanning vereist. Over het geheel genomen zou het aandeel van de vrouwelijke leerlingen in de primaire opleiding in 1997 met maar liefst 18\%-punt moeten zijn gestegen tot $44 \%$ van de totale instroom. In 2001 zou het aandeel van de vrouwen in de totale instroom zelfs $46 \%$ moeten zijn. 
Het tweede beleidsscenario heeft betrekking op het verhogen van de instroom van wat gezien kan worden als de harde kern van de voortijdig schoolverlaters: degenen die zonder een LBO- of MAVO-diploma het initiële dagonderwijs verlaten.

Uit de prognoseresultaten van dit scenario blijkt dat in 1997 voor 10 van de 20 landelijke organen waarvoor in het basisscenario een leerlingentekort wordt verwacht, dit tekort in principe zou kunnen worden voorkomen door het vergroten van de ongediplomeerde instroom. In het jaar 2001 is dit nog slechts bij 6 van de 20 organen het geval. Wel zou dit betekenen dat bij nogal wat organen vrijwel de gehele potentiële doelgroep voor een opleiding in het leerlingwezen zou moeten gaan kiezen. Ook bij de andere landelijke organen is doorgaans een zeer forse toename van de ongediplomeerde instroom vereist. Bij de organen waarvoor relatief grote aanbodtekorten worden verwacht biedt het vergroten van de ongediplomeerde instroom met name bij de ECABO, de SVB, de SBW, de BETEX en de SVEB de mogelijkheid om het toekomstige leerlingentekort te verminderen. Naast ongediplomeerde LBO- en MAVOschoolverlaters zullen dan ook veel meer ongediplomeerde HAVO- en VWO-ers moeten worden aangetrokken.

Het derde alternatieve scenario verkent de mogelijkheden om de instroom van het leerlingwezen te vergroten door het dualiseren van de parallelle KMBO-opleidingen. Alhoewel dit beleidsscenario voor een aantal organen waarvoor een parallel opleidingstraject in het KMBO ontbreekt geen rol kan spelen bij het verminderen van het verwachte leerlingentekort, mag toch verwacht worden dat het dualiseren van de KMBO-opleidingen voor 8 van de 20 landelijke organen waarvoor op grond van het basisscenario in 1997 een tekort wordt verwacht, mogelijkheden biedt om dit tekort te voorkomen. In 2001 is dit nog slechts bij 5 organen het geval. Voor de organen waarvoor relatief grote tekorten worden verwacht, biedt dualisering van het KMBO alleen bij de ECABO de mogelijkheid om ee toekomstig leerlingentekort te voorkomen.

Tenslotte is nagegaan in hoeverre een beleidsscenario gericht op het verhogen van het interne rendement van de primaire opleidingen de toekomstige vraag-aanbod verhoudingen in het leerlingwezen in evenwicht zou kunnen brengen. De uitkomsten van dit scenario laten zien dat bij maar liefst 16 van de 20 organen waarvoor in 1997 een tekortschietend leerlingenaanbod wordt verwacht, een verhoging van het interne rendement deze tekorten theoretisch gezien zou kunnen voorkomen. In 2001 is dit bij nog 15 landelijke organen het geval. Voor enkele organen zou dit echter betekenen dat het rendement onwaarschijnlijk hoog zou moeten zijn. Voor het leerlingwezen in totaal zou het interne rendement van de primaire opleidingen in 1997 op $70 \%$ moeten komen te liggen. Dit impliceert een toename van maar liefst 17\%-punt ten opzichte van het gemiddelde rendement van de primaire opleidingen in de periode 1986-1991. In het jaar 2001 zou het gemiddelde rendement op $80 \%$ moeten komen te liggen om de verwachte tekorten, voor zover dit langs deze weg mogelijk is, te doen verdwijnen. Bij de organen waarvoor de grootste leerlingentekorten worden verwacht zou dit beleidsscenario alleen bij de SBW, de SVB en de ECABO het verwachte tekort in zowel 1997 als 2001 kunnen voorkomen, op voorwaarde dat men een aanzienlijke toename van het interne rendement zou weten te 
realiseren.

In de verschillende beleidsscenario's die in deze studie nader zijn uitgewerkt, is steeds een partiële benadering gevolgd door telkens te kijken in hoeverre alleen via de desbetreffende weg de op grond van het basisscenario verwachte tekorten zouden kunnen worden voorkomen. Bij de ECABO zou het volgen van één van de vier beleidsscenario's reeds voldoende kunnen zijn om de verwachte tekorten in 1997 te voorkomen. Alleen het verhogen van de ongediplomeerde instroom in de primaire opleidingen zou ook voor dit orgaan onvoldoende soelaas bieden. Het dualiseren van $\mathrm{KMBO}$-opleidingen of het verhogen van het interne rendement van de primaire opleidingen zou bij de ECABO ook voldoende effect kunnen hebben om de voor het jaar 2001 verwachte tekorten te voorkomen.

Bij de SBW zou het verhogen van de instroom van vrouwen of het verhogen van het interne rendement een vraag-aanbod evenwicht kunnen bewerkstelligen, al biedt het verhogen van de instroom van vrouwen bij dit orgaan alleen voor 1997 soelaas. In principe zou een verhoging van het interne rendement ook de verwachte toekomstige leerlingentekorten bij de SBW kunnen voorkomen. Dit vereist echter wel een onwaarschijnlijk hoog rendement.

Al met al kan geconcludeerd worden dat de verwachte tekorten, met name bij die landelijke organen waarvoor relatief grote leerlingentekorten worden verwacht, alleen adequaat bestreden kunnen worden wanneer op meerdere terreinen beleidsinspanningen worden verricht. Daarbij mag verwacht worden dat met name het bewerkstelligen van een substantiële verhoging van het interne rendement van de primaire opleidingen voor veel organen een effectief middel zou kunnen zijn om de op grond van het basisscenario verwachte aanbodtekorten te voorkomen. Echter, ook de andere beleidscenario's bieden wel degelijk mogelijkheden om de verwachte leerlingentekorten aanzienlijk te reduceren. Bij een beleid gericht op het verhogen van de instroom van vrouwen zou het effect overigens nog groter kunnen zijn wanneer getracht zou worden meer vrouwen aan te trekken met een andere opleidingsachtergrond dan de traditionele vooropleidingen waaruit het desbetreffende orgaan leerlingen recruteert.

Tot de landelijke organen waarvoor relatief grote tekorten worden verwacht behoren ook de organen waarvoor wordt aangenomen dat de vereiste instroom tot 1997 aanzienlijk toeneemt: de SLW, de VAS en de BETEX. Vanwege het ontbreken van middellange-termijn doelstellingen op dit punt bij de landelijke organen kon deze voor de toekomst vereiste instroom slechts gebaseerd worden op de ontwikkelingstrend van de streefcijfers in het kader van de Bijdrageregeling Vakopleiding Leerlingwezen in de jaren 1990-1992. Het zou wenselijk zijn de in deze studie gegenereerde prognoses van het leerlingenaanbod te confronteren met op meer systematische wijze opgestelde prognoses van de te verwachte vraag naar leerlingen. Daarbij zou kunnen worden aangesloten bij het door De Grip, Heijke en Lodder (1992) ontwikkelde modellering van de invloed van vraagfactoren op de ontwikkelingen in het leerlingwezen. In een dergelijke analyse zou ook getracht kunnen worden om het effect van beleidsinstrumenten als de Bijdrageregeling Vakopleiding Leerlingwezen te traceren. 


\section{LITERATUUR}

Adviescommissie inzake de Voortgang van het Industriebeleid (1983), Verslag van werkzaamheden 2, 's-Gravenhage.

Baars, W.J., M.A.A. Castelein-de Boer, L.C. d'Artillac Brill, P.J. Goedhart (red.) (1992), MBOalmanak 1992 met gegevens over het leerlingwezen, Samson H.D. Tjeenk Willink, Alphen aan den Rijn.

Baars, W.S. (1988), Intensivering en vernieuwing van het leerlingwezen; terreinverkenning en plan van aanpak, Projectmanagement Leerlingwezen, 's Gravenhage.

Bal, J.M., J.F.M. de Jonge (1989), Allochtonen in het leerlingwezen; een onderzoek naar de positie van allochtonen in de praktijkcomponent van het leerlingwezen in Rotterdam, Ministerie van Sociale Zaken en Werkgelegenheid, 's Gravenhage.

Beereboom, H.J.A. (1987), De vakopleiding van jongeren in de bouw, Economisch Instituut voor de Bouwnijverheid, Amsterdam.

Beereboom, H.J.A. (1991), Uitval uit het leerlingwezen; een onderzoek naar de achtergronden van voortijdige beëindigingen van leerovereenkomsten in de primaire opleidingen van het leerlingwezen in de b. en u., Economisch Instituut voor de Bouwnijverheid, Amsterdam.

Bont-Hoek, J.G.M. de, Th.H.C. de Haas, P.Th. Kraft (1989), Aanpak van de uitval; resultaten van een vooronderzoek naar de uitval in het leerlingwezen, Pedagogisch Centrum Beroepsonderwijs Bedrijfsleven, 's-Hertogenbosch.

Borghans, L., J.A.M. Heijke (1993), Het voorspellen van de beroepenstructuur van bedrijfstakken binnen het kader van het Athena-model, ROA, Maastricht.

CBA (1992), Bijdrageregeling Vakopleiding Leerlingwezen (BVL) 1992/1993, Centraal Bureau Arbeidsvoorziening, Rijswijk.

COLO (1989), Aktieplan LO '90; voorstellen voor een beleidsprogramma van de landelijke opleidingsorganen voor de negentiger jaren, Stichting Centraal Orgaan van de Landelijke Opleidingsorganen van het Bedrijfsleven, Zoetermeer.

Diederen, J. (1987), Beroepsloopbaan na KMBO of $B B O$, Instituut voor Toegepaste Sociale Wetenschappen, Nijmegen.

Doelman, S., M. de Loor, P.S.F.M. van den Acker (1992), Verkenning Carrosseriebranche 1992-1997, Riphagen Reiche \& de Vos, 's Gravenhage. 
Frietman, J.E.M. (1990), De kwaliteit van de praktijkcomponent in het leerlingwezen; een studie over de ontwikkelingen in en de kwaliteit van de praktijkopleiding in het primair leerlingwezen, Instituut voor Toegepaste Sociale Wetenschappen, Nijmegen.

Frietman, J., B. Hövels (1990), Leerlingwezen als opleidingsweg in en van het bedrijfsleven, in: Jeugd en Samenleving, 1990/10, pp. 631-637.

Gaalen-Oordijk, C.E. van, A.F. Westerhuis (1989), Naar een uniforme rendementsmeting en uitvalregistratie in het leerlingwezen, Ministerie van Sociale Zaken en Werkgelegenheid, OAVrapport 1989-008, Rijswijk.

Ganga, V. (1992), Deelname, uitval en rendement van het leerlingwezen, Ministerie van Onderwijs en Wetenschappen, Directie Beroepsonderwijs en Volwasseneneducatie, 's Gravenhage.

Gelderblom, A., A.H.C. Hammink (1991), Rendement in de volwasseneducatie, RVE Adviescentrum Volwasseneducatie, Utrecht.

Geurts, J. (1989), Van niemandsland naar beroepenstructuur; een studie over de aans/uiting tussen onderwijs en arbeid op het niveau van aankomend vakmanschap, Instituut voor Toegepaste Sociale Wetenschappen, Nijmegen.

Grip, A. de, J.A.M. Heijke, B.J.H. Lodder (1992), De invloed van vraagfactoren op de markt voor leerovereenkomsten, ROA-RM-1992/3, Maastricht.

Hövels, B.W.M. (1985), Arbeidsorganisaties en het leerlingwezen; een onderzoek naar het aanbod van leer-arbeidsplaatsen door arbeidsorganisaties, Ministerie van Sociale Zaken en Werkgelegenheid, 's Gravenhage.

Hövels, B., H. Verijdt (1987), Naar een versterking van het leerlingwezen; een onderzoek naar beleidsinstrumenten ter versterking van de praktijkcomponent van het leerlingwezen, Instituut voor Toegepaste Sociale Wetenschappen, Nijmegen.

Imhoff, E. van (1986), De evaluatie van de school- en beroepsloopbaan van KMBO en BBO/LWleerlingen met behulp van kansmodellen, in: Hartog. J., J.M.M. Ritzen (red.) (1986), Economische aspecten van onderwijs, Swets \& Zeitlinger, Lisse, pp. 87-100.

Kleine, W. de, R. Stevens (1989), Invallen over uitval; een onderzoek naar de uitvaloorzaken van leerlingen en de belangrijkste knelpunten in de primaire opleidingen van de SVS, Stichting Vakopleiding Schilders- en Stukadoorsbedrijf, Waddinxveen.

Lodder, B.J.H., A. de Grip, J.A.M. Heijke (1992), In- en uitstroom op de markt voor leerovereenkomsten, ROA-RM-1992/1, Maastricht. 
Merkus, H.W. (1990), Uitval bij de VAPRO; Verslag van een onderzoek naar factoren die samenhangen met uitval bij het leerlingstelsel VaPro, Interlimites, Hilversum.

Ministerie van Onderwijs en Wetenschappen (1984), Op weg naar een gezamenlijke verantwoordelijkheid, Eindrapport van het Open Overleg over de voorstellen van de commissie Wagner inzake het beroepsonderwijs, Staatsuitgeverij, 's Gravenhage.

Ministerie van Onderwijs en Wetenschappen (1992), Referentieraming 1992, Ministerie van Onderwijs en Wetenschappen, 's-Gravenhage.

Ministerie van Onderwijs en Wetenschappen (1993), Een goed voorbereidende start, Tweede Kamer, vergaderjaar 1992-1993, 22994, nr. 1, 's-Gravenhage.

Neve, J.H. (1991), Zonder diploma uit het deeltijdonderwijs; een kwantitatief onderzoek naar de omvang van de ongediplomeerde in- en uitstroom bij enige vormen van deeltijdonderwijs, Ministerie van Sociale Zaken en Werkgelegenheid, 's-Gravenhage.

PML (1989), Een optelsom van appels en peren; Advies over de registratie van leerovereenkomsten, Projectmanagement Leerlingwezen, 's Gravenhage.

SER (1990), Rendement van het onderwijs, Sociaal-Economische Raad, publikatie nr. 8, 'sGravenhage.

Tijdelijke Adviescommissie Onderwijs en Arbeidsmarkt (1990), Onderwijs-arbeidsmarkt: naar een werkzaam traject, Samson H.D. Tjeenk Willink, Alphen aan den Rijn.

Vereniging BVE, LDC, AOC-Raad (1993), Studiegids MBO en leerlingwezen 1993, Vereniging BVE/LDC/AOC-Raad.

Verijdt, H. (1991), De instroom van nieuwe doelgroepen in het leerlingwezen, Instituut voor Toegepaste Sociale Wetenschappen, Nijmegen. 



\section{BIJLAGE A. LANDELIJKE ORGANEN VOOR HET LEERLINGWEZEN}

\begin{tabular}{|c|c|}
\hline BETEX & Stichting Beroepsopleidingen Textielindustrie \\
\hline ECABO & $\begin{array}{l}\text { Stichting Landelijk Orgaan ter Bevordering van Opleidingen voor de Economische } \\
\text { en Administratieve Beroepencategorie }\end{array}$ \\
\hline GOC & Grafisch Opleidingscentrum \\
\hline INNOVAM & Innovatie- en Onderwijscentrum Motorvoertuigen- en Tweewielersbranche \\
\hline IVOB & Instituut Vorming Opleiding Beveiliging \\
\hline KOF & Stichting Koninklijk Onderwijsfonds voor de Scheepvaart \\
\hline LSBC & $\begin{array}{l}\text { Landelijk Orgaan Leerlingwezen van de Stichting Praktijkonderwijs } \\
\text { Leerlingwezen voor Bosbouw, Cultuurtechniek en Groene Sector }\end{array}$ \\
\hline LSBL & Landelijke Stichting Beroepsopleiding in de Levensmiddelenindustrie \\
\hline OVD & Stichting Landelijk Orgaan Opleidingen voor de Distributie \\
\hline OVDB & Landelijke Stichting Opleiding Verzorgende en Dienstverlenende Beroepen \\
\hline SBW & Stichting Beroepsopleidingen Weg- en Waterbouw \\
\hline SH\&M & Stichting Vakopleiding Hout- \& Meubileringsbedrijf \\
\hline SLHV & $\begin{array}{l}\text { Stichting ter Bevordering van het Leerlingwezen in het Haven- en Vervoerbedrijf in } \\
\text { Nederland }\end{array}$ \\
\hline SLW & Stichting Leerlingstelsel Wegvervoer \\
\hline SOI & Stichting Opleidingen Installatietechniek \\
\hline SOM & Stichting Opleidingen Metaal \\
\hline SVB & Stichting Vakopleiding Bouwbedrijf \\
\hline SVEB & Stichting voor Vakopleiding en Examens in het Bakkersbedrijf \\
\hline SVGB & Stichting Vakopleiding Gezondheidstechnische Beroepen \\
\hline SVH & $\begin{array}{l}\text { Stichting Vakopleiding Horeca (Leerlingstelsel Horeca, Contract-catering en } \\
\text { Instellingskeuken) }\end{array}$ \\
\hline SVK & Stichting Vakopleiding Kappersbedrijf \\
\hline SVO & Slagersvakopleiding (Opleiding voor de vleessector) \\
\hline SVS & Stichting Vakopleiding Schilders- en Stukadoorsbedrijf \\
\hline VAPRO & Stichting Vakopleiding Procesindustrie \\
\hline VAS & Stichting Vakopleiding Schoen- en Lederwarenindustrie \\
\hline VBOB & Vereniging tot Bevordering van Opleidingen in de Banketbakkersbranche \\
\hline VEV & Vereniging Elektrotechnisch Vakonderwijs \\
\hline VOC (car) & Stichting Vakopleiding Carrosseriebedrijf \\
\hline VOC (conf) & Stichting Vakopleiding Confectie Industrie \\
\hline VOLLT & $\begin{array}{l}\text { Landelijke Stichting Vakopleidingen Leerlingwezen Land- en } \\
\text { Groenvoorziening en Bloemenbranche }\end{array}$ \\
\hline VVA & Vereniging ter Veredeling van de Ambacht \\
\hline
\end{tabular}



$-74-$

BIJLAGE B. JAARCIJFERS SAMENSTELLING INSTROOM, 1978-1991

Tabel B.1. Instroom in het primaire leerlingwezen naar vooropleiding, 1978-1991

\begin{tabular}{|c|c|c|c|c|c|c|c|c|c|}
\hline Jaar & $\begin{array}{c}\text { LTOMD } \\
\%\end{array}$ & $\begin{array}{r}\text { LHNOMD } \\
\%\end{array}$ & $\begin{array}{c}\text { LMOMD } \\
\%\end{array}$ & $\begin{array}{c}\text { LEAOMD } \\
\%\end{array}$ & $\begin{array}{r}\text { MAVOMD } \\
\%\end{array}$ & $\begin{array}{c}\text { LTOZD } \\
\%\end{array}$ & $\begin{array}{c}\text { OVTRADZD } \\
\%\end{array}$ & $\begin{array}{c}\text { Ovo } \\
\%\end{array}$ & $\begin{array}{c}\text { totaal } \\
\%\end{array}$ \\
\hline 1978 & 62,5 & 10,1 & 0,1 & 1,4 & 5,9 & 9,6 & 6,7 & 3,5 & 100 \\
\hline 1979 & 55,4 & 12,5 & 0,2 & 1,3 & 7,0 & 9,1 & 7,6 & 6,8 & 100 \\
\hline 1980 & 58,7 & 10,0 & 0,2 & 1,5 & 8,3 & 8,6 & 5,9 & 6,8 & 100 \\
\hline 1981 & 57,4 & 15,5 & 0,3 & 1,3 & 9,1 & 6,6 & 5,0 & 4,7 & 100 \\
\hline 1982 & 57,3 & 16,4 & 0,2 & 1,5 & 9,4 & 5,9 & 4,5 & 4,7 & 100 \\
\hline 1983 & 59,5 & 13,3 & 0,2 & 1,3 & 10,3 & 5,3 & 4,5 & 5,6 & 100 \\
\hline 1984 & 59,6 & 13,5 & 0,2 & 1,7 & 10,6 & 4,2 & 3,8 & 6,4 & 100 \\
\hline 1985 & 60,3 & 11,4 & 0,2 & 1,7 & 11,8 & 3,3 & 3,2 & 8,0 & 100 \\
\hline 1986 & 60,5 & 13,7 & 0,1 & 1,3 & 9,5 & 3,6 & 2,7 & 8,5 & 100 \\
\hline 1987 & 57,7 & 13,3 & 0,2 & 2,0 & 9,8 & 4,1 & 3,4 & 9,5 & 100 \\
\hline 1988 & 56,1 & 12,3 & 0,2 & 2,1 & 10,0 & 4,1 & 3,6 & 11,6 & 100 \\
\hline 1989 & 48,7 & 11,7 & 0,3 & 2,4 & 9,8 & 4,2 & 3,9 & 19,1 & 100 \\
\hline 1990 & 48,4 & 11,9 & 0,3 & 2,7 & 10,4 & 3,7 & 3,9 & 18,7 & 100 \\
\hline 1991 & 47,2 & 11,1 & 0,2 & 2,3 & 9,8 & 4,8 & 4,9 & 19,8 & 100 \\
\hline
\end{tabular}

Bron: CBS/O\&W/CORO/ROA 
Tabel B.2. Instroom in het primaire leerlingwezen per landelijk orgaan naar vooropleiding, 1978

\begin{tabular}{|c|c|c|c|c|c|c|c|c|c|}
\hline $\begin{array}{l}\text { Landelijk } \\
\text { orgaan } \mathrm{L}\end{array}$ & $\begin{array}{r}\text { TOMD } \\
\%\end{array}$ & $\begin{array}{r}\text { LHNOMD } \\
\%\end{array}$ & $\begin{array}{r}\text { LMOMD } \\
\%\end{array}$ & $\begin{array}{c}\text { LEAOMD } \\
\%\end{array}$ & $\begin{array}{r}\text { MAVOMD } \\
\%\end{array}$ & $\begin{array}{c}\text { LTOZD } \\
\%\end{array}$ & $\begin{array}{c}\text { OVTRADZD } \\
\%\end{array}$ & $\begin{array}{c}\text { OVo } \\
\%\end{array}$ & $\begin{array}{c}\text { totaal } \\
\%\end{array}$ \\
\hline OVD & 6,0 & 55,0 & 0,1 & 4,8 & 4,8 & 4,3 & 22,8 & 2,4 & 100 \\
\hline ECABO & 2,1 & 32,2 & 0,2 & 11,8 & 41,5 & 0,6 & 8,8 & 2,7 & 100 \\
\hline SLW & 67,9 & 2,2 & 0,0 & 2,2 & 7,5 & 10,4 & 6,7 & 3,0 & 100 \\
\hline SOM & 87,8 & 0,0 & 0,0 & 0,5 & 3,1 & 5,1 & 1,2 & 2,3 & 100 \\
\hline SVB & 85,0 & 0,0 & 0,0 & 0,2 & 2,0 & 9,8 & 1,6 & 1,4 & 100 \\
\hline SVS & 75,6 & 0,1 & 0,1 & 0,3 & 3,0 & 15,4 & 3,3 & 2,3 & 100 \\
\hline INNOVAM & 79,8 & 0,0 & 0,1 & 1,0 & 3,9 & 9,9 & 2,8 & 2,5 & 100 \\
\hline VBOB & 63,2 & 0,0 & 0,1 & 0,0 & 0,3 & 25,9 & 0,7 & 9,9 & 100 \\
\hline VEV & 90,5 & 0,0 & 0,0 & 0,4 & 2,2 & 3,4 & 1,0 & 2,4 & 100 \\
\hline SVGB & 45,8 & 0,4 & 0,8 & 3,6 & 21,3 & 2,4 & 8,0 & 17,7 & 100 \\
\hline GOC & 52,9 & 0,4 & 0,5 & 3,6 & 15,1 & 11,7 & 7,3 & 8,7 & 100 \\
\hline VOC (conf) & 0,1 & 52,1 & 0,0 & 0,5 & 2,1 & 0,2 & 42,4 & 2,6 & 100 \\
\hline SVH & 61,8 & 4,0 & 0,1 & 2,0 & 8,8 & 14,8 & 5,4 & 3,2 & 100 \\
\hline VAS & 5,3 & 18,7 & 0,0 & 5,3 & 12,0 & 6,7 & 38,7 & 13,3 & 100 \\
\hline VAPRO & 47,8 & 0,1 & 0,4 & 1,2 & 16,0 & 7,7 & 6,0 & 20,9 & 100 \\
\hline OVDB & 0,2 & 80,2 & 0,2 & 0,1 & 0,6 & 0,2 & 10,2 & 8,3 & 100 \\
\hline SBW & 48,4 & 0,0 & 0,0 & 2,2 & 8,9 & 28,3 & 8,5 & 3,8 & 100 \\
\hline VOC (car) & 77,9 & 0,0 & 0,0 & 0,7 & 3,8 & 14,7 & 1,8 & 1,1 & 100 \\
\hline BETEX & 39,4 & 1,0 & 0,0 & 8,1 & 14,1 & 19,2 & 11,1 & 7,1 & 100 \\
\hline SH\&M & 71,9 & 0,2 & 0,1 & 0,7 & 4,2 & 17,3 & 2,8 & 2,8 & 100 \\
\hline SVEB & 68,7 & 0,4 & 0,4 & 1,7 & 5,8 & 17,2 & 2,2 & 3,4 & 100 \\
\hline SVK & 0,4 & 41,0 & 0,0 & 0,1 & 13,6 & 0,3 & 40,3 & 4,3 & 100 \\
\hline svo & 27,0 & 2,9 & 1,2 & 4,6 & 14,9 & 25,5 & 16,2 & 7,8 & 100 \\
\hline SOI & 79,8 & 0,0 & 0,0 & 0,2 & 3,5 & 13,0 & 1,8 & 1,6 & 100 \\
\hline
\end{tabular}

Bron: CORO/ROA 
$-76-$

Tabel B.3. Instroom in het primaire leerlingwezen per landelijk orgaan naar vooropleiding, 1985

\begin{tabular}{|c|c|c|c|c|c|c|c|c|c|}
\hline $\begin{array}{l}\text { Landelijk } \\
\text { orgaan } L T\end{array}$ & $\begin{array}{r}\text { LTOMD } \\
\%\end{array}$ & $\begin{array}{r}\text { LHNOMD } \\
\%\end{array}$ & $\begin{array}{r}\text { LMOMD } \\
\%\end{array}$ & $\begin{array}{c}\text { LEAOMD } \\
\%\end{array}$ & $\begin{array}{r}\text { MAVOMD } \\
\%\end{array}$ & $\begin{array}{c}\text { LTOZD } \\
\%\end{array}$ & $\begin{array}{c}\text { OVTRADZD } \\
\%\end{array}$ & $\begin{array}{c}\text { ovo } \\
\%\end{array}$ & $\begin{array}{c}\text { totaal } \\
\%\end{array}$ \\
\hline OVD & 8,3 & 48,8 & 0,7 & 9,1 & 14,5 & 2,1 & 9,7 & 6,8 & 100 \\
\hline ECABO & 8,0 & 8,1 & 0,5 & 11,2 & 35,4 & 0,8 & 5,6 & 30,5 & 100 \\
\hline SLW & 91,7 & 0,2 & 0,0 & 0,4 & 6,8 & 0,3 & 0,1 & 0,5 & 100 \\
\hline SOM & 79,2 & 0,1 & 0,1 & 0,5 & 8,6 & 2,6 & 1,1 & 7,8 & 100 \\
\hline SVB & 94,4 & 0,0 & 0,0 & 0,0 & 0,8 & 2,1 & 0,4 & 2,4 & 100 \\
\hline SVS & 78,6 & 0,1 & 0,2 & 0,3 & 4,6 & 10,0 & 2,1 & 3,9 & 100 \\
\hline INNOVAM & 78,5 & 0,1 & 0,2 & 0,6 & 9,1 & 4,6 & 1,5 & 5,5 & 100 \\
\hline VBOB & 78,0 & 4,1 & 0,0 & 0,0 & 1,5 & 11,4 & 0,5 & 4,5 & 100 \\
\hline VEV & 79,0 & 0,3 & 0,1 & 0,2 & 7,2 & 2,2 & 0,8 & 10,2 & 100 \\
\hline SVGB & 23,4 & 5,2 & 1,0 & 3,6 & 34,9 & 1,0 & 4,7 & 26,0 & 100 \\
\hline GOC & 48,7 & 1,4 & 0,4 & 2,6 & 22,5 & 3,8 & 4,3 & 16,3 & 100 \\
\hline VOC (conf) & 2,7 & 63,8 & 0,0 & 2,4 & 4,8 & 0,3 & 16,2 & 9,9 & 100 \\
\hline SVH & 64,4 & 5,6 & 0,3 & 1,5 & 11,9 & 5,9 & 3,0 & 7,5 & 100 \\
\hline VAS & 16,4 & 30,1 & 0,0 & 8,2 & 16,4 & 5,5 & 16,4 & 6,8 & 100 \\
\hline VAPRO & 59,6 & 0,1 & 0,0 & 0,9 & 21,7 & 2,5 & 2,3 & 12,7 & 100 \\
\hline OVDB & 1,7 & 91,0 & 0,0 & 0,3 & 1,6 & 0,0 & 3,6 & 1,6 & 100 \\
\hline SBW & 70,9 & 0,0 & 0,0 & 0,9 & 11,2 & 8,9 & 1,9 & 6,2 & 100 \\
\hline VOC (car) & 75,5 & 0,0 & 0,5 & 0,9 & 7,9 & 7,7 & 2,6 & 4,9 & 100 \\
\hline BETEX & 57,2 & 5,9 & 0,0 & 2,7 & 15,3 & 3,6 & 3,6 & 11,7 & 100 \\
\hline SH\&M & 79,4 & 0,9 & 0,2 & 1,0 & 4,5 & 4,8 & 1,5 & 7,7 & 100 \\
\hline SVEB & 77,7 & 0,7 & 0,4 & 1,0 & 6,4 & 6,5 & 2,5 & 4,8 & 100 \\
\hline SVK & 3,0 & 44,9 & 0,0 & 1,1 & 35,0 & 0,4 & 13,3 & 2,2 & 100 \\
\hline svo & 39,2 & 16,7 & 1,4 & 4,2 & 17,2 & 6,9 & 4,8 & 9,5 & 100 \\
\hline SOI & 81,3 & 0,1 & 0,0 & 0,6 & 6,4 & 5,5 & 1,2 & 4,9 & 100 \\
\hline
\end{tabular}

Bron: CORO/ROA 
Tabel B.4. Instroom in het primaire leerlingwezen per landelijk orgaan naar vooropleiding, 1991

\begin{tabular}{|c|c|c|c|c|c|c|c|c|c|}
\hline $\begin{array}{l}\text { Landelijk } \\
\text { orgaan } \mathrm{L}\end{array}$ & $\begin{array}{r}\text { LTOMD } \\
\%\end{array}$ & $\begin{array}{r}\text { LHNOMD } \\
\%\end{array}$ & $\begin{array}{r}\text { LMOMD } \\
\%\end{array}$ & $\begin{array}{r}\text { LEAOMD } \\
\%\end{array}$ & $\begin{array}{r}\text { MAVOMD } \\
\%\end{array}$ & $\begin{array}{c}\text { LTOZD } \\
\%\end{array}$ & $\begin{array}{c}\text { OVTRADZD } \\
\%\end{array}$ & $\begin{array}{c}\text { OVo } \\
\%\end{array}$ & $\begin{array}{c}\text { totaal } \\
\%\end{array}$ \\
\hline OVD & 12,4 & 33,2 & 0,9 & 7,9 & 13,2 & 2,7 & 10,4 & 19,2 & 100 \\
\hline ECABO & 7,3 & 11,3 & 0,5 & 12,1 & 18,7 & 1,3 & 10,2 & 38,6 & 100 \\
\hline SLW & 86,7 & 0,7 & 0,0 & 0,8 & 4,1 & 1,5 & 0,5 & 5,7 & 100 \\
\hline SOM & 69,7 & 0,3 & 0,1 & 0,3 & 7,0 & 3,4 & 0,7 & 18,5 & 100 \\
\hline SVB & 72,6 & 0,2 & 0,1 & 0,7 & 4,0 & 6,8 & 1,6 & 14,0 & 100 \\
\hline SVS & 60,7 & 0,4 & 0,1 & 1,5 & 5,1 & 14,3 & 4,0 & 13,9 & 100 \\
\hline INNOVAM & 68,5 & 0,1 & 0,2 & 0,5 & 8,1 & 4,7 & 1,7 & 16,3 & 100 \\
\hline VBOB & 49,9 & 3,2 & 0,4 & 0,8 & 10,8 & 22,0 & 1,2 & 11,7 & 100 \\
\hline VEV & 55,4 & 0,2 & 0,0 & 0,3 & 6,7 & 3,2 & 1,4 & 32,7 & 100 \\
\hline SVGB & 15,2 & 2,4 & 0,1 & 1,9 & 25,0 & 1,3 & 2,6 & 51,5 & 100 \\
\hline GOC & 36,6 & 2,4 & 0,3 & 3,0 & 22,2 & 3,8 & 3,7 & 28,0 & 100 \\
\hline VOC (conf) & 7,6 & 43,5 & 0,0 & 0,8 & 4,0 & 3,2 & 18,2 & 22,8 & 100 \\
\hline SVH & 49,4 & 6,0 & 0,2 & 2,0 & 12,4 & 5,5 & 4,2 & 20,3 & 100 \\
\hline VAS & 18,6 & 23,7 & 0,0 & 1,7 & 3,4 & 11,9 & 11,9 & 28,8 & 100 \\
\hline VAPRO & 82,1 & 2,3 & 0,0 & 0,1 & 3,8 & 4,1 & 0,6 & 7,0 & 100 \\
\hline OVDB & 2,3 & 73,9 & 0,1 & 0,2 & 3,5 & 0,0 & 11,2 & 8,8 & 100 \\
\hline SBW & 65,7 & 0,2 & 0,0 & 1,1 & 8,6 & 9,6 & 1,5 & 13,2 & 100 \\
\hline VOC (car) & 62,9 & 0,3 & 0,2 & 0,8 & 6,9 & 10,1 & 2,3 & 16,5 & 100 \\
\hline BETEX & 33,9 & 2,2 & 0,2 & 3,0 & 12,4 & 9,0 & 3,4 & 35,9 & 100 \\
\hline SH\&M & 69,1 & 0,8 & 0,1 & 0,7 & 4,8 & 7,2 & 1,3 & 16,0 & 100 \\
\hline SVEB & 71,4 & 0,9 & 0,0 & 0,5 & 9,1 & 6,9 & 1,3 & 9,8 & 100 \\
\hline SVK & 4,7 & 29,4 & 0,2 & 4,4 & 22,9 & 2,2 & 18,0 & 18,3 & 100 \\
\hline SVO & 31,1 & 15,4 & 1,3 & 3,9 & 15,0 & 10,0 & 5,8 & 17,5 & 100 \\
\hline sol & 59,7 & 0,4 & 0,2 & 0,7 & 6,8 & 7,9 & 2,5 & 21,9 & 100 \\
\hline
\end{tabular}

Bron: CORO/ROA 


\section{BIJLAGE C. VRAGENLIJST M.B.T. INFORMATIE OVER BELEIDSDOELSTELLIN- GEN LANDELIJKE ORGANEN}

Naam opleidingsorgaan:

1. Heeft uw opleidingsorgaan een streefcijfer met betrekking tot het (jaarlijkse) aantal nieuw af te sluiten primaire leerovereenkomsten?
[ ] ja
[ ] nee

2. Heeft uw opleidingsorgaan een streefcijfer met betrekking tot het (jaarlijkse) aantal nieuw af te sluiten voortgezette leerovereenkomsten?
[ ] ja
[ ] nee

3. Heeft uw opleidingsorgaan een streefcijfer met betrekking tot het jaarlijkse aantal ges/aagden voor de primaire opleidingen die onder uw orgaan vallen?
[ ] ja
[ ] nee

4. Heeft uw opleidingsorgaan een streefcijfer met betrekking tot het jaarlijkse aantal geslaagden voor de voortgezette opleidingen die onder uw orgaan vallen?
[ ] ja
[ ] nee

5. Indien u éen of meer van de vragen 1 tot en met 4 met ja hebt beantwoord, wie is dan de contactpersoon voor de desbetreffende gegevens?

naam:

functie:

telefoonnummer:. 

BIJLAGE D. JAARCIJFERS INSTROOMPROGNOSES, 1993-2001

Tabel D.1. Verwachte instroom in het primaire leerlingwezen per landelijk orgaan volgens het basisscenario, 1993-2001 (absolute aantallen)

\begin{tabular}{|c|c|c|c|c|c|c|c|c|c|}
\hline $\begin{array}{l}\text { Landelijk } \\
\text { orgaan }\end{array}$ & 1993 & 1994 & 1995 & 1996 & 1997 & 1998 & 1999 & 2000 & 2001 \\
\hline OVD & 3.055 & 3.041 & 3.271 & 3.462 & 3.880 & 4.046 & 4.147 & 4.198 & 4.339 \\
\hline ECABO & 1.421 & 1.296 & 1.343 & 1.277 & 1.459 & 1.369 & 1.287 & 1.213 & 1.257 \\
\hline SLW & 721 & 678 & 689 & 716 & 898 & 968 & 920 & 807 & 749 \\
\hline SOM & 3.006 & 2.847 & 2.874 & 2.908 & 3.419 & 3.557 & 3.358 & 2.984 & 2.773 \\
\hline SVB & 2.247 & 2.130 & 2.161 & 2.206 & 2.611 & 2.734 & 2.594 & 2.316 & 2.167 \\
\hline SVS & 959 & 907 & 921 & 931 & 1.078 & 1.118 & 1.062 & 953 & 893 \\
\hline INNOVAM & 2.253 & 2.170 & 2.276 & 2.332 & 2.892 & 3.039 & 2.903 & 2.606 & 2.507 \\
\hline VBOB & 261 & 259 & 283 & 293 & 347 & 360 & 354 & 338 & 340 \\
\hline VEV & 3.534 & 3.264 & 3.212 & 3.139 & 3.614 & 3.672 & 3.406 & 2.968 & 2.731 \\
\hline SVGB & 322 & 346 & 402 & 421 & 504 & 518 & 531 & 546 & 590 \\
\hline GOC & 876 & 859 & 921 & 914 & 1.061 & 1.053 & 1.004 & 934 & 917 \\
\hline VOC (conf) & 360 & 354 & 365 & 383 & 409 & 425 & 431 & 430 & 432 \\
\hline SVH & 1.903 & 1.853 & 1.941 & 1.981 & 2.290 & 2.358 & 2.286 & 2.140 & 2.084 \\
\hline VAS & 28 & 26 & 26 & 26 & 28 & 28 & 28 & 26 & 26 \\
\hline VAPRO & 1.012 & 966 & 992 & 1.043 & 1.304 & 1.423 & 1.374 & 1.227 & 1.152 \\
\hline OVDB & 2.042 & 1.916 & 1.939 & 2.048 & 2.192 & 2.277 & 2.297 & 2.263 & 2.253 \\
\hline SBW & 669 & 615 & 615 & 610 & 729 & 751 & 696 & 599 & 547 \\
\hline VOC (car) & 649 & 641 & 682 & 713 & 857 & 909 & 892 & 834 & 820 \\
\hline BETEX & 140 & 143 & 156 & 162 & 188 & 194 & 193 & 189 & 193 \\
\hline SH\&M & 743 & 701 & 706 & 715 & 840 & 875 & 826 & 731 & 676 \\
\hline SVEB & 412 & 379 & 381 & 379 & 457 & 473 & 438 & 377 & 343 \\
\hline SVK & 2.406 & 2.398 & 2.612 & 2.687 & 3.001 & 3.029 & 3.046 & 3.045 & 3.127 \\
\hline svo & 906 & 890 & 952 & 980 & 1.119 & 1.147 & 1.133 & 1.093 & 1.093 \\
\hline sol & 1.436 & 1.382 & 1.422 & 1.444 & 1.690 & 1.754 & 1.675 & 1.515 & 1.437 \\
\hline Totaal & 31.360 & 30.063 & 31.143 & 31.771 & 36.868 & 38.078 & 36.881 & 34.332 & 33.447 \\
\hline
\end{tabular}

Bron: ROA 

$-80-$

\section{BIJLAGE E. JAARCIJFERS PROGNOSES AANBODOVERSCHOTTEN EN -TEKORTEN, 1993-2001}

Tabel E.1. Verwachte aanbodoverschotten en -tekorten aan nieuwe leerlingen in het primaire leerlingwezen volgens het basisscenario, 1993-2001 (absolute aantallen)

\begin{tabular}{|c|c|c|c|c|c|c|c|c|c|}
\hline $\begin{array}{l}\text { Landelijk } \\
\text { orgaan }\end{array}$ & 1993 & 1994 & 1995 & 1996 & 1997 & 1998 & 1999 & 2000 & 2001 \\
\hline OVD & -1.460 & -1.699 & -1.706 & -1.765 & -1.608 & -1.442 & -1.341 & -1.290 & -1.149 \\
\hline ECABO & -784 & -909 & -862 & -928 & -746 & -836 & -918 & -992 & -948 \\
\hline SLW & -1.661 & -1.942 & -2.193 & -2.454 & -2.589 & -2.519 & -2.567 & -2.680 & -2.738 \\
\hline SOM & -1.554 & -1.713 & -1.686 & -1.652 & -1.141 & -1.003 & -1.202 & -1.576 & -1.787 \\
\hline SVB & -1.753 & -1.870 & -1.839 & -1.794 & -1.389 & -1.266 & -1.406 & -1.684 & -1.833 \\
\hline SVS & -521 & -573 & -559 & -549 & -402 & -362 & -418 & -527 & -587 \\
\hline INNOVAM & -547 & -630 & -524 & -468 & 92 & 239 & 103 & -194 & -293 \\
\hline VBOB & -164 & -166 & -142 & -132 & -78 & -65 & -71 & -87 & -85 \\
\hline VEV & -1.466 & -1.736 & -1.788 & -1.861 & -1.386 & -1.328 & -1.594 & -2.032 & -2.269 \\
\hline SVGB & -136 & -112 & -56 & -37 & 46 & 60 & 73 & 88 & 132 \\
\hline GOC & -624 & -641 & -579 & -586 & -439 & -447 & -496 & -566 & -583 \\
\hline VOC (conf) & -51 & -57 & -46 & -28 & -2 & 14 & 20 & 19 & 21 \\
\hline SVH & -1.062 & -1.112 & -1.024 & -984 & -675 & -607 & -679 & -825 & -881 \\
\hline VAS & -38 & -46 & -54 & -62 & -69 & -68 & -69 & -70 & -71 \\
\hline VAPRO & -438 & -484 & -485 & -407 & -146 & -27 & -76 & -223 & -298 \\
\hline OVDB & -188 & -314 & -291 & -182 & -38 & 47 & 67 & 33 & 23 \\
\hline SBW & -431 & -485 & -485 & -490 & -371 & -349 & -404 & -501 & -553 \\
\hline VOC (car) & -371 & -379 & -338 & -307 & -163 & -111 & -128 & -186 & -200 \\
\hline BETEX & -193 & -224 & -247 & -282 & -300 & -294 & -295 & -299 & -295 \\
\hline SH\&M & -462 & -504 & -499 & -490 & -365 & -330 & -379 & -474 & -529 \\
\hline SVEB & -348 & -381 & -379 & -381 & -303 & -287 & -322 & -383 & -417 \\
\hline SVK & 106 & 98 & 312 & 387 & 701 & 729 & 746 & 745 & 827 \\
\hline svo & -550 & -566 & -504 & -476 & -337 & -309 & -323 & -363 & -363 \\
\hline sOI & -959 & -1.013 & -973 & -951 & -705 & -641 & -720 & -880 & -958 \\
\hline Totaal & -15.656 & -17.457 & -16.920 & -16.877 & -12.411 & -11.201 & -12.399 & -14.947 & -15.833 \\
\hline
\end{tabular}

Bron: ROA 
